ENVIRONMENTAL RESTORATION PROGRAM

\section{Toxicological Benchmarks for Screening Potential Contaminants of Concern for Effects on Aquatic Biota: 1996 Revision}

This document has been approved by the K-25 Site Technical Information Office for release to the public. Date: $6-26-46$

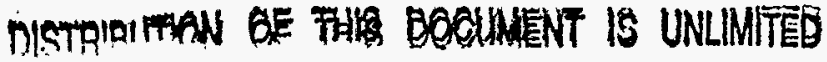


This report has been reproduced directly from the best available copy.

Available to DOE and DOE contractors from the Office of Scientific and Technical Information, P.O. Box 62, Oak Ridge, TN 37831; prices available from 423-576-8401 (fax 423-576-2865).

Available to the public from the National Technical Information Service, U.S. Department of Commerce, 5285 Port Royal Rd., Springfield, VA 22161. 
June 28, 1996

Ms. T. C. Perry

Program Manager

Environmental Restoration Division

Department of Energy

Oak Ridge Operations Office

P.O. Box 2001

Oak Ridge, Tennessee 37831-8541

Dear Ms. Perry:

Contract DE-AC05-840R21400, Transmittal of Toxicological Benchmarks for Screening Potential Contaminants of Concern for Effects on Aquatic Biota: 1996 Revision (ES/ER/TM-96/R2)

Enclosed you will find a copy of the subject report. As indicated by the document number, this is a revised report; therefore, previous versions of this report should be discarded. The purpose of this document is to present revised potential screening benchmarks for protection of aquatic life from contaminants in water. This document represents a completed milestone for the Environmental Restoration Risk Assessment Program.

If you have any questions or comments regarding this document, please contact me at (423) 576-2734 or Glenn Suter at (423) 574-7306.

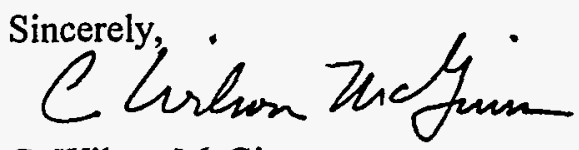

C. Wilson McGinn

Risk Assessment Manager

CWM:sk

Enclosure

cc/encl: $\quad$ R. K. Holmes .

S. B. Kerr

File-ER Document Management Center-RC

cc w/o encl: $\quad$ S. P. Riddle, DOE-ORO 


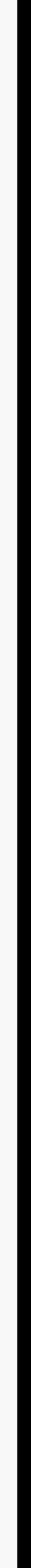




\title{
Toxicological Benchmarks \\ for Screening Potential \\ Contaminants of Concern \\ for Effects on Aquatic Biota: \\ 1996 Revision
}

\author{
G. W. Suter II
}

C. L. Tsao

Date Issued-June 1996

\footnotetext{
Prepared by

Risk Assessment Program

Health Sciences Research Division

Oak Ridge, Tennessee 37831

Prepared for the

U.S. Department of Energy

Office of Environmental Management

under budget and reporting code EW 20
}

\section{LOCKHEED MARTIN ENERGY SYSTEMS, INC.}

managing the

Environmental Management Activities at the

Oak Ridge K-25 Site Paducah Gaseous Diffusion Plant

Oak Ridge Y-12 Plant Portsmouth Gaseous Diffusion Plant

Oak Ridge National Laboratory

under contract DE-AC05-84OR21400

for the

U.S. DEPARTMENT OF ENERGGY 



\begin{abstract}
AUTHOR AFFILIATIONS
G. W. Suter II is a member of the Environmental Sciences Division, Oak Ridge National Laboratory, Oak Ridge, Tennessee. C. L. Tsao is affiliated with the School of the Environment, Duke University, Durham, North Carolina.
\end{abstract}





\section{PREFACE}

The purpose of this report is to present and analyze alternate toxicological benchmarks for screening chemicals for aquatic ecological effects. This work was performed under Work Breakdown Structure 1.4.12.2.3.04.05.04 (Activity Data Sheet 8304, "Technical Integration-Risk Assessment"). Publication of this document meets a milestone for the Environmental Restoration (ER) Risk Assessment Program. Since the prior edition of this report (Suter and Mabrey 1994), both the U.S. Environmental Protection Agency Office of Solid Waste and Emergency Response and EPA Region IV have developed sets of screening benchmarks for water. This report includes those values and updates the other benchmarks that were presented in the last edition. 



\section{CONTENTS}

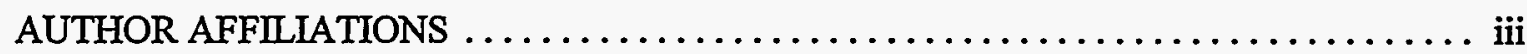

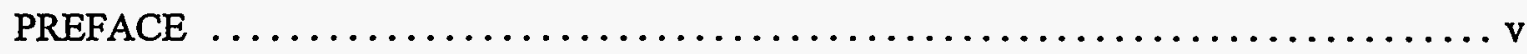

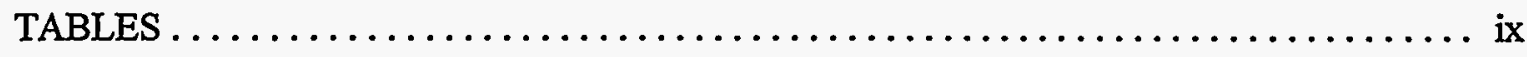

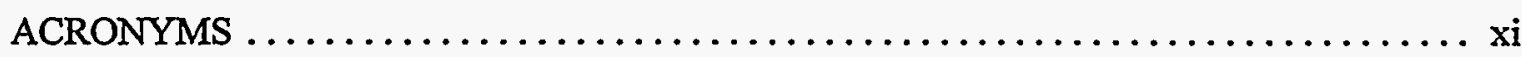

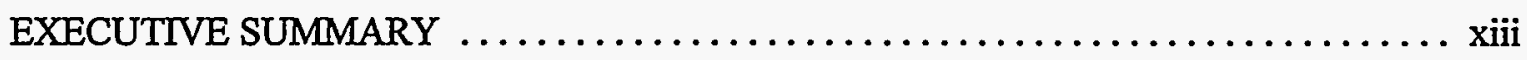

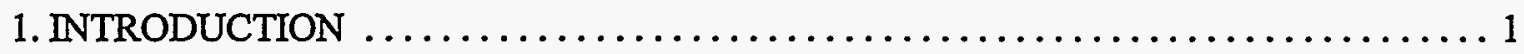

2. METHODS FOR DERIVING BENCHMARKS $\ldots \ldots \ldots \ldots \ldots \ldots \ldots \ldots \ldots \ldots \ldots$

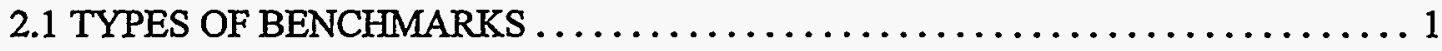

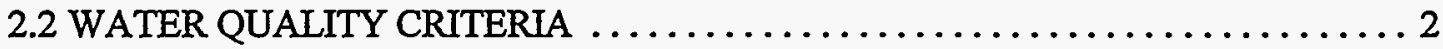

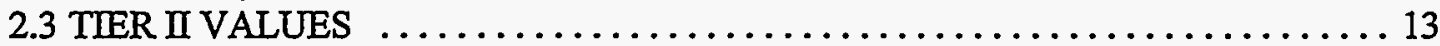

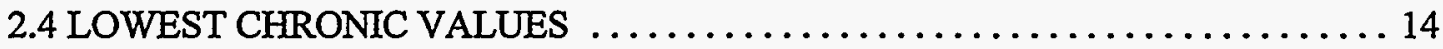

2.5 ESTIMATED LOWEST CHRONIC VALUES $\ldots \ldots \ldots \ldots \ldots \ldots \ldots \ldots \ldots \ldots \ldots \ldots$

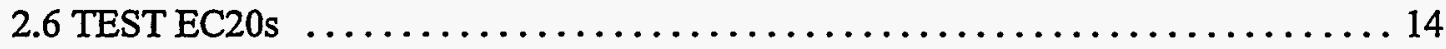

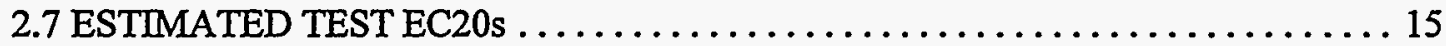

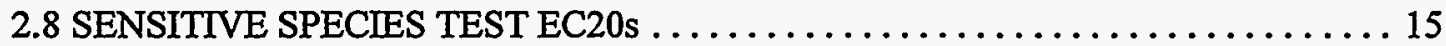

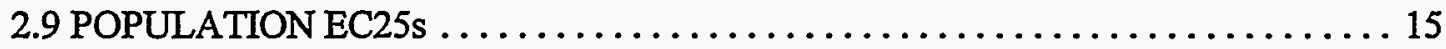

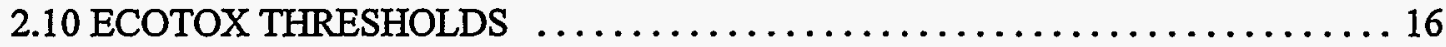

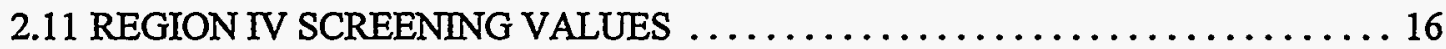

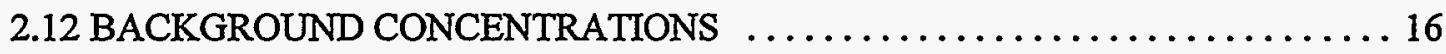

3. CHEMICAL-SPECIFIC INFORMATION $\ldots \ldots \ldots \ldots \ldots \ldots \ldots \ldots \ldots \ldots \ldots \ldots \ldots \ldots \ldots \ldots, 22$

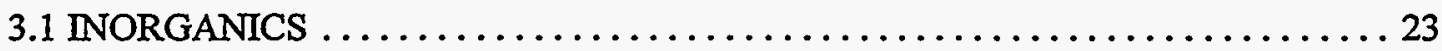

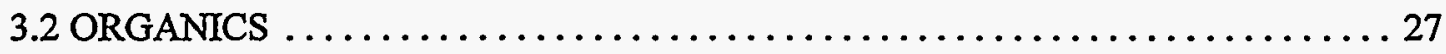

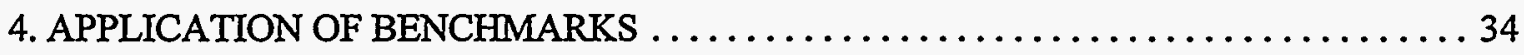

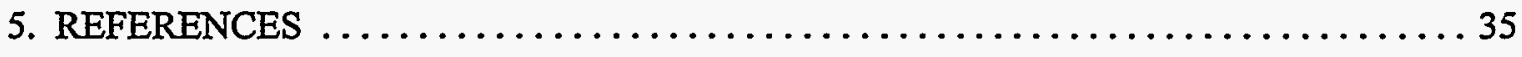

Appendix A DATA USED FOR TIER II CALCULATIONS $\ldots \ldots \ldots \ldots \ldots \ldots \ldots \ldots$ A-1

Appendix B METHODS FOR DERIVATION OF TIER II VALUES $\ldots \ldots \ldots \ldots \ldots \ldots$ B-1

Appendix C TABLE SHOWING CONCENTRATIONS ESTIMATED

TO CAUSE A 20\% REDUCTION IN THE RECRUIT

ABUNDANCE OF LARGEMOUTH BASS, WITH UPPER

AND LOWER $95 \%$ CONFIDENCE BOUNDS ................. C-1 


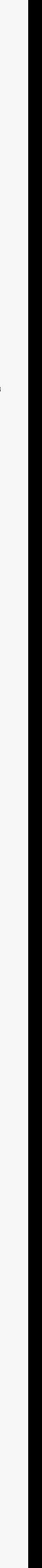




\section{TABLES}

1 Summary of conventional benchmarks for priority contaminants in fresh water .......

2 Summary of alternative benchmarks for priority contaminants in fresh water based

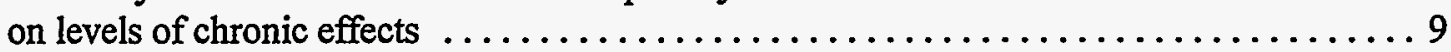

3 Summary of OSWER threshold values for aquatic life (EPA 1996) and Region IV screening values for freshwater surface water $\ldots \ldots \ldots \ldots \ldots \ldots \ldots \ldots 17$

A.1 Data and calculated results for derivation of Tier II values $\ldots \ldots \ldots \ldots \ldots \ldots \ldots \ldots \ldots \ldots \ldots \ldots \ldots \ldots \ldots \ldots$

B.1 Factors for estimation of the Tier II values $\ldots \ldots \ldots \ldots \ldots \ldots \ldots \ldots \ldots \ldots \ldots \ldots$

C.1 Concentrations estimated to cause a $20 \%$ reduction in the recruit abundance of largemouth bass, with upper and lower $95 \%$ confidence bounds $\mathrm{C}-3$ 



\section{ACRONYMS}

ACRs

ARARs

CERCLA

CV

EC50

EPA

ETs

FACR

FAV

FCV

GLWQI

GMAV

LC50

LOEC

MATC

NAWQC

NOEC

OSWER

RI

SACR

SAV

SCV

SS

SVs acute chronic ratios

applicable or relevant and appropriate requirements

Comprehensive Environmental Response, Compensation, and Liability Act

Chronic Value

median effective concentration

U.S. Environmental Protection Agency

Ecotox Thresholds

Final Acute-Chronic Ratio

Final Acute Value

final chronic value

Great Lakes Water Quality Initiative

genus mean acute value

median lethal concentration

Lowest Observed Effect Co

Maximum Acceptable Toxicant Concentration

National Ambient Water Quality Criteria

No Observed Effect Concentration

Office of Solid Waste and Emergency Response

Remedial Investigation

secondary acute chronic ratio

Secondary Acute Values

Secondary Chronic Value

sensitive species

screening values 



\section{EXECUTIVE SUMMARY}

One of the initial stages in ecological risk assessment of hazardous waste sites is the screening of contaminants to determine which, if any, of them are worthy of further consideration; this process is termed contaminant screening. Screening is performed by comparing concentrations in ambient media to benchmark concentrations that are either indicative of a high likelihood of significant effects (upper screening benchmarks) or of a very low likelihood of significant effects (lower screening benchmarks). Exceedance of an upper screening benchmark indicates that the chemical in question is clearly of concern and remedial actions are likely to be needed. Exceedance of a lower screening benchmark indicates that a contaminant is of concern unless other information indicates that the data are unreliable or the comparison is inappropriate. Chemicals with concentrations below the lower benchmark are not of concern if the ambient data are judged to be adequate.

This report presents potential screening benchmarks for protection of aquatic life from contaminants in water. Because there is no guidance for screening benchmarks, a set of alternative benchmarks is presented herein. The alternative benchmarks are based on different conceptual approaches to estimating concentrations causing significant effects. For the upper screening benchmark, there are the acute National Ambient Water Quality Criteria (NAWQC) and the Secondary Acute Values (SAV). The SAV concentrations are values estimated with $80 \%$ confidence not to exceed the unknown acute NAWQC for those chemicals with no NAWQC. The alternative chronic benchmarks are the chronic NAWQC, the Secondary Chronic Value (SCV), the lowest chronic values for fish and daphnids, the lowest EC20 for fish and daphnids from chronic toxicity tests, the estimated EC20 for a sensitive species, and the concentration estimated to cause a $20 \%$ reduction in the recruit abundance of largemouth bass. It is recommended that ambient chemical concentrations be compared to all of these benchmarks. If NAWQC are exceeded, the chemicals must be contaminants of concern because the NAWQC are applicable or relevant and appropriate requirements (ARARs). If NAWQC are not exceeded, but other benchmarks are, contaminants should be selected on the basis of the number of benchmarks exceeded and the conservatism of the particular benchmark values, as discussed in the text.

To the extent that toxicity data are available, this report presents the alternative benchmarks for chemicals that have been detected on the Oak Ridge Reservation. It also presents the data used to calculate the benchmarks and the sources of the data. It compares the benchmarks and discusses their relative conservatism and utility.

This report supersedes a prior aquatic benchmarks report (Suter and Mabrey 1994). It adds two new types of benchmarks. It also updates the benchmark values where appropriate, adds some new benchmark values, replaces secondary sources with primary sources, and provides more complete documentation of the sources and derivation of all values. 


\section{INTRODUCTION}

An important early step in the assessment of ecological risks posed by a contaminated site is the screening of contaminants. In many cases, concentrations in water will be reported for more than 100 chemicals, most of which will be reported as undetected at some defined limit of detection. The assessor must decide which of the detected chemicals constitute an ecological hazard and which of the undetected chemicals may pose a hazard at concentrations below the reported detection limits. This screening is done by comparing the reported concentrations to toxicological benchmarks. If concentrations of a chemical exceed its benchmark for a particular medium, then it is worthy of further measurement and assessment. If not, it can be ignored (assuming that the analytical data are adequate).

In practice, a series of benchmarks of differing conservatism may be used. Exceedance of an upper screening benchmark would suggest a severe hazard and a need for urgent action. Nonexceedance of all lower screening benchmarks would suggest no hazard. Exceedance of an increasing number of benchmarks would constitute increasing evidence of the need for measurement and assessment. In addition to providing a better indication of the magnitude of the hazard, the use of multiple benchmarks provides information about the nature of the hazard which can be used in development of the conceptual model and in planning the Remedial Investigation (RD). For example, is the chemical at concentrations that are toxic to only daphnids, to daphnids and fish, to fish and aquatic plants, etc.? Are they at concentrations that have been demonstrated to be toxic or do they exceed only benchmarks that include conservative factors?

The purpose of this report is to present and analyze alternate toxicological benchmarks for screening chemicals for aquatic ecological effects. Since the prior edition of this report (Suter and Mabrey 1994), both the U.S. Environmental Protection Agency (EPA) Office of Solid Waste and Emergency Response (OSWER) and EPA Region IV have developed sets of screening benchmarks for water. This report includes those values and updates the other benchmarks that were presented in the last edition.

This compilation is limited to chemicals that have been detected on the Oak Ridge Reservation and to benchmarks derived from studies of toxic effects on fresh water organisms. The list of chemicals detected on the Oak Ridge Reservation includes 45 metals and 105 industrial chemicals. Only four pesticides occur on the list, and those are persistent and wide-spread (chlordane, DDT, heptachlor, and lindane).

\section{METHODS FOR DERIVING BENCHMARKS}

\subsection{TYPES OF BENCHMARKS}

The simplest screening benchmarks are toxicity test endpoints. A test endpoint is a statistically derived numeric summary of the results of a toxicity test. Test endpoints can be calculated in two ways. First, a level of effect can be estimated by fitting a function such as the probit or logit to the concentration-response data to derive a concentration-response model. Then by inverse regression, a concentration can be estimated that causes a particular level of effect such as the median lethal concentration (LC50). Second, hypothesis testing statistics can be used to determine whether each 
of the tested concentrations caused an effect that was statistically significantly different from the controls. The lowest concentration causing such an effect is termed the Lowest Observed Effect Concentration (LOEC); the highest concentration for which there were no such effects is termed the No Observed Effect Concentration (NOEC). The geometric mean of the LOEC and NOEC is termed the Chronic Value (CV) and was formerly termed the Maximum Acceptable Toxicant Concentration (MATC).

Toxicity tests are conventionally divided into acute and chronic tests. Standard acute aquatic toxicity tests are 48 or 96 hours in duration and use juvenile or adult organisms; the test endpoints are the median lethal concentration (LC50) or median effective concentration (EC50) for death or some equivalent effect (e.g., immobilization). Standard chronic tests include all or most of the lifecycle of the test organisms, and they include observations of growth, defornaities, and reproductive success as well as lethality. The standard endpoint for chronic tests is the $\mathrm{CV}$.

Another important distinction is between response-specific and integrative endpoints. Conventionally, NOECs and LOECs are calculated for each response parameter, and the results for the most statistically sensitive parameter are reported. Because effects on populations and ecosystems are a result of the integrated effects of the toxicant on all life stages, it is more sensible to integrate the responses in the test when calculating the test endpoint. Integrative endpoints may be simple arithmetic combinations of effects such as the proportional mortality across all tested life stages or population parameters derived from simple models such as the intrinsic rate of natural increase, $r$.

Benchmarks may be combinations of multiple test endpoints. An example is the chronic NAWQC, which are derived from at least eight LC50s and three CVs.

Finally, benchmarks may be derived by using mathematical models to simulate an assessment endpoint, a specific environmental characteristic that is valued and is at risk due to the contamination or disturbance that is being assessed (Suter 1989). For example, in this study we present concentrations estimated to correspond to a $20 \%$ reduction in recruit abundance for largemouth bass (Micropterus salmoides) because production of fish, particularly game fish, is an assessment endpoint for Oak Ridge Reservation ecological risk assessments (Suter et al. 1992).

Conventional aquatic benchmarks, which are based on regulatory criteria or standard test endpoints used to derive criteria, are listed in Table 1. Unconventional aquatic benchmarks, which are based on levels of effects on integrative endpoints, are listed in Table 2.

\subsection{WATER QUALITY CRITERIA}

The National Ambient Water Quality Criteria (NAWQC) are applicable or relevant and appropriate requirements (ARARs); therefore, they provide the basis for the screening benchmarks for contaminants in water. The acute NAWQC are calculated by the EPA as half the Final Acute Value (FAV), which is the fifth percentile of the distribution of 48- to 96-hour LC50 values or equivalent median effective concentration (EC50) values for each criterion chemical (Stephan et al. 1985). The acute NAWQC are intended to correspond to concentrations that would cause less than $50 \%$ mortality in $5 \%$ of exposed populations in a brief exposure. They may be used as a reasonable upper screening benchmark because waste site assessments are concerned with sublethal effects and largely with continuous exposures, rather than the lethal effects and episodic exposures to which the acute NAWQC are applied. The chronic NAWQC are the FAVs divided by the Final Acute-Chronic Ratio (FACR), which is the geometric mean of quotients of at least three LC50/CV 
Table 1. Summary of conventional benchmarks for priority contaminants in fresh water (all values in micrograms per liter)

\begin{tabular}{|c|c|c|c|c|c|c|c|c|c|}
\hline \multirow{2}{*}{ Chemical } & \multicolumn{2}{|c|}{ NAWQ Criteria } & \multicolumn{2}{|c|}{ Tier II Values } & \multirow{2}{*}{ Fish } & \multicolumn{3}{|c|}{ Lowest Chronic Value for: } & \multirow[b]{2}{*}{$\begin{array}{l}\text { All Organ- } \\
\text { isms }\end{array}$} \\
\hline & Acute & Chronic & $\begin{array}{l}\text { Secondary } \\
\text { Acute } \\
\text { Value }\end{array}$ & $\begin{array}{c}\text { Secondary } \\
\text { Chronic } \\
\text { Valuc }\end{array}$ & & Daphnids & $\begin{array}{c}\text { Non- } \\
\text { Daphnid } \\
\text { Inverte- } \\
\text { brates }\end{array}$ & $\begin{array}{l}\text { Aquatic } \\
\text { Plants }\end{array}$ & \\
\hline Aluminum & 750 & 87 & & & 3,288 & 1,900 & & 460 & 460 \\
\hline Ammonia & $\mathrm{pH}$ and & erature & & & 1.7 & 630 & & 2,400 & 1.7 \\
\hline Antimony & & & $180^{\prime}$ & $30^{1}$ & 1,600 & 5,400 & & 610 & 610 \\
\hline Arsenic III & 360 & 190 & & & 2,962 & 914.1 & & 2,320 & 914.1 \\
\hline Arsenic V & & $\cdot$ & 66 & 3.1 & 892 & $* 450$ & & 48 & 48 \\
\hline Barium & & & 110 & 4.0 & & & & & \\
\hline Beryllium & & & 35 & 0.66 & *57 & 5.3 & & 100,000 & 5.3 \\
\hline Boron & & & 30 & 1.6 & & 8,830 & & & 8,830 \\
\hline Cadmium & $3.9+$ & $1.1+$ & & & 1.7 & 0.15 & & 2 & 0.15 \\
\hline Calcium & & & & & & 116,000 & & & 116,000 \\
\hline Chromium III & $1,700+$ & $210+$ & & & 68.63 & $<44$ & & 397 & $<44$ \\
\hline Chromium VI & 16 & 11 & & & 73.18 & 6.132 & & 2 & - \\
\hline Cobalt & & & 1500 & 23 & 290 & 5.1 & & & 5.1 \\
\hline Copper & $18+$ & $12+$ & & & 3.8 & 0.23 & 6.066 & 1 & 0.23 \\
\hline Cyanide & 22 & 5.2 & & & 7.8 & & 18.33 & 30 & 7.8 \\
\hline Iron & & 1,000 & & & 1,300 & 158 & & & 158 \\
\hline Lead & $82+$ & $3.2+$ & & & 18.88 & 12.26 & 25.46 & 500 & 12.26 \\
\hline Lithium & & & 260 & 14 & & & & & \\
\hline Magnesium & & & & & & 82,000 & & & 82,000 \\
\hline Manganese & & & 2,300 & 120 & 1780 & $<1,100$ & & & $<1,100$ \\
\hline Mercury, inorganic or total & 2.4 & & & $1.30^{\circ}$ & $<0.23$ & 0.96 & & 5 & $<0.23$ \\
\hline Mercury, methyl & & & 0.099 & 0.0028 & 0.52 & $<0.04$ & & $0.8-4.0$ & $<0.04$ \\
\hline Molybdenum & & & 16,000 & 370 & & 880 & & & 880 \\
\hline
\end{tabular}


Table 1. (continued)

\begin{tabular}{|c|c|c|c|c|c|c|c|c|c|}
\hline \multirow{2}{*}{ Chemical } & \multicolumn{2}{|c|}{ NAWQ Criteria } & \multicolumn{2}{|c|}{ Tier II Values } & \multicolumn{5}{|c|}{ Lowest Chronic Value for: } \\
\hline & Acute & Chronic & $\begin{array}{c}\text { Secondary } \\
\text { Acute } \\
\text { Value }\end{array}$ & $\begin{array}{c}\text { Secondary } \\
\text { Chronic } \\
\text { Value }\end{array}$ & Fish & Daphnids & $\begin{array}{c}\text { Non- } \\
\text { Daphnid } \\
\text { Inverte- } \\
\text { brates } \\
\end{array}$ & $\begin{array}{l}\text { Aquatic } \\
\text { Plants }\end{array}$ & $\begin{array}{l}\text { All Organ- } \\
\text { isms }\end{array}$ \\
\hline Nickel & $1,400+$ & $160+$ & & & $<35$ & $<5$ & 128.4 & 5 & $<5$ \\
\hline Potassium & & & & & & 53,000 & & & 53,000 \\
\hline Selenium & 20 & 5 & & & 88.32 & 91.65 & & 100 & 88.32 \\
\hline Silver & $4.1+$ & & & 0.36 & 0.12 & 2.6 & & 30 & 0.12 \\
\hline Sodium & & & & & & 680,000 & & & 680,000 \\
\hline Strontium & & & 15,000 & 1,500 & & 42,000 & & & 42,000 \\
\hline Thallium & & & 110 & 12 & 57 & 130 & & 100 & 57 \\
\hline Tin & & & 2,700 & 73 & & 350 & & & 350 \\
\hline Uranium & & & 46 & 2.6 & *142 & & & & *142 \\
\hline Vanadium & & & 280 & 20 & 80 & 1,900 & & & 80 \\
\hline Zinc & $120+$ & $110+$ & & & 36.41 & 46.73 & $>5,243$ & 30 & 30 \\
\hline Zirconium & & & 310 & 17 & $* 548$ & & & & *548 \\
\hline & & & & Organics & & & & & \\
\hline Acenaphthene & $80^{\circ}$ & $23^{\circ}$ & & & 74 & $* 6,646$ & 227 & 520 & 74 \\
\hline Acetone & & & 28,000 & 1,500 & $* 507,640$ & 1,560 & & & $* 507,640$ \\
\hline Anthracene & & & 13 & 0.73 & $* 0.09$ & $<2.1$ & & & $* 0.09$ \\
\hline Benzene & & & 2,300 & 130 & & $>98,000$ & & 525,000 & 525,000 \\
\hline Benzidene & & & 70 & 3.9 & $* 134$ & & & & $* 134$ \\
\hline Benzo(a)anthracene & & & 0.49 & 0.027 & & $* 0.65$ & & & $* 0.65$ \\
\hline Benzo(a)pyrene & & & 0.24 & 0.014 & & $* 0.30$ & & & $* 0.30$ \\
\hline Benzoic acid & & & 740 & 42 & ${ }^{*} 12,976$ & & & & $* 12,976$ \\
\hline Benzyl alcohol & & & 150 & 8.6 & $* 589$ & & & & $* 589$ \\
\hline
\end{tabular}


Table 1. (continued)

\begin{tabular}{|c|c|c|c|c|c|c|c|c|c|}
\hline \multirow{2}{*}{ Chemical } & \multicolumn{2}{|c|}{ NAWQ Criteria } & \multicolumn{2}{|c|}{ Tier II Values } & \multicolumn{5}{|c|}{ Lowest Chronic Value for: } \\
\hline & Acute & Chronic & $\begin{array}{c}\text { Secondary } \\
\text { Acute } \\
\text { Value }\end{array}$ & $\begin{array}{l}\text { Secondary } \\
\text { Chronic } \\
\text { Value }\end{array}$ & Fish & Daphnids & $\begin{array}{c}\begin{array}{c}\text { Non- } \\
\text { Daphnid } \\
\text { Inverte- } \\
\text { brates }\end{array} \\
\end{array}$ & $\begin{array}{l}\text { Aquatic } \\
\text { Plants }\end{array}$ & $\begin{array}{l}\text { All Organ- } \\
\text { isms }\end{array}$ \\
\hline BHC (lindane) & 2 & 0.08 & & & 14.6 & 14.5 & 3.3 & 500 & 3.3 \\
\hline BHC (other) & & & 39 & 2.2 & & $* 95$ & & & *95 \\
\hline Biphenyl & & & & $14^{r}$ & & & & & \\
\hline Bis(2-ethylhexyl)phthalate & & & 27 & 3.0 & & 912 & & & 912 \\
\hline 4-Bromophenyl phenyl cther & & & & $1.5^{r}$ & & & & & \\
\hline Butylbenzyl phthalate & & & & $19^{r}$ & & & & & \\
\hline 2-Butanone & & & 240,000 & 14,000 & $* 282,170$ & ${ }^{*} 1,394,927$ & & & $* 282,170$ \\
\hline Carbon disulfide & & & 17 & 0.92 & $* 9,538$ & $* 244$ & & & *244 \\
\hline Carbon tetrachloride & & & 180 & 9.8 & 1,970 & $* 5,580$ & & & 1,970 \\
\hline Chlordane & 2.4 & $0.17^{2}$ & & & 1.6 & 16 & 1.09 & & 1.09 \\
\hline Chlorobenzene & & & 1,100 & 64 & $* 1,203$ & $* 15,042$ & & 224,000 & $*_{1203}$ \\
\hline Chloroform & & & 490 & 28 & 1,240 & $* 4,483$ & & & 1,240 \\
\hline DDD p,p' & & & 0.19 & 0.011 & $* 1.69$ & & & & $* 1.69$ \\
\hline DDT & 1.1 & & & $0.013^{\text {br }}$ & $0.73^{c}$ & $* 0.016$ & & 0.3 & 0.3 \\
\hline Decane & & & 880 & 49 & & $* 7,874$ & & & $* 7,874$ \\
\hline Di-n-butyl phthalate & & & 190 & 35 & $717^{d}$ & 697 & & & 697 \\
\hline Diazinon & & & $0.17^{8}$ & $0.043^{8}$ & & & & & \\
\hline Dibenzofuran & & & 66 & 3.7 & & $* 1,003$ & & & $* 1,003$ \\
\hline 1,2-Dichlorobenzene & & & $260^{r}$ & $14^{r}$ & & & & & \\
\hline 1,3-Dichlorobenzene & & & $630^{\circ}$ & $71^{r}$ & & & & & \\
\hline 1,4-Dichlorobenzene & & & $180^{r}$ & $15^{r}$ & & & & & \\
\hline 1,1-Dichloroethane & & & 830 & 47 & $* 14,680$ & & & & $* 14,680$ \\
\hline 1,2-Dichloroethane & & & 8,800 & 910 & 41,364 & 15,200 & & & 15,200 \\
\hline
\end{tabular}


Table 1. (continued)

\begin{tabular}{|c|c|c|c|c|c|c|c|c|c|}
\hline \multirow{2}{*}{ Chemical } & \multicolumn{2}{|c|}{ NAWQ Criteria } & \multicolumn{2}{|c|}{ Tier II Values } & \multicolumn{5}{|c|}{ Lowest Chronic Value for: } \\
\hline & Acute & Chronic & $\begin{array}{l}\text { Secondary } \\
\text { Acute } \\
\text { Value }\end{array}$ & $\begin{array}{c}\text { Secondary } \\
\text { Chronic } \\
\text { Value }\end{array}$ & Fish & Daphnids & $\begin{array}{c}\text { Non- } \\
\text { Daphnid } \\
\text { Inverte- } \\
\text { brates }\end{array}$ & $\begin{array}{c}\text { Aquatic } \\
\text { Plants }\end{array}$ & $\begin{array}{l}\text { All Organ- } \\
\text { isms }\end{array}$ \\
\hline 1,1-Dichloroethene & & & 450 & 25 & $>2,800$ & $* 4,720$ & & $>798,000$ & $>2,800$ \\
\hline 1,2-Dichlorocthene & & & 1,100 & 590 & $* 9,538$ & & & & $* 9,538$ \\
\hline 1,3-Dichloropropene & & & 0.99 & 0.055 & 244 & $* 805$ & & 4,950 & 244 \\
\hline Dieldrin & $0.18^{\mathrm{e}}$ & $0.062^{\circ}$ & & & & & & & \\
\hline Diethyl phthalate & & & 1,800 & 210 & & & & 85,600 & 85,600 \\
\hline Di-n-octyl phthalate & & & & & 3,822 & 708 & & & 708 \\
\hline Endosulfan, all isomers & & & & $0.051^{t}$ & & & & & \\
\hline Endrin & $0.095^{\mathrm{e}}$ & $0.061^{\circ}$ & & & & & & & \\
\hline Ethyl benzene & & & 130 & 7.3 & $>440$ & $* 12,922$ & & $>438,000$ & $>440$ \\
\hline Fluoranthene & $33.6^{\mathrm{e}}$ & $6.16^{\mathrm{e}}$ & & & 30 & 15 & & 54400 & 15 \\
\hline Fluorene & & & $70^{r}$ & $3.9^{r}$ & & & & & \\
\hline Heptachlor & & & $0.125^{g, h}$ & $0.0069^{b, 8}$ & 1.26 & $* 3.18$ & & 26.7 & 1.26 \\
\hline Hexachloroethane & & & $210^{\circ}$ & $12^{f}$ & & & & & \\
\hline Hexane & & & 10 & 0.58 & $\div 65,712$ & & & & $* 65,712$ \\
\hline 2-Hexanone & & & 1,800 & 99 & $* 32,783$ & & & & $* 32,783$ \\
\hline Methoxychlor & & & & $0.019^{r}$ & & & & & \\
\hline 1-Methylnaphthalene & & & 37 & 2.1 & $* 526$ & & & & $* 526$ \\
\hline 4-Methyl-2-pentanone & & & 2,200 & 170 & 77,400 & & & & 77,400 \\
\hline 2-Methylphenol & & & 230 & 13 & $* 489$ & $* 1,316$ & & & $* 489$ \\
\hline Methylene chloride & & & 26,000 & 2,200 & 108,000 & $* 42,667$ & & & $* 42,667$ \\
\hline Naphthalene & & & 190 & 12 & 620 & $* 1,163$ & & 33,000 & 620 \\
\hline 4-Nitrophenol & & & 1,200 & 300 & $* 481$ & 7,100 & & 4190 & $* 481$ \\
\hline N-Nitrosodiphenylamine & & & 3,800 & 210 & $* 332$ & $* 1,042$ & & & $* 332$ \\
\hline
\end{tabular}


Table 1. (continued)

\begin{tabular}{|c|c|c|c|c|c|c|c|c|c|}
\hline \multirow{2}{*}{ Chemical } & \multicolumn{2}{|c|}{ NAWQ Criteria } & \multicolumn{2}{|c|}{ Tier II Values } & \multirow[b]{2}{*}{ Fish } & \multicolumn{3}{|c|}{ Lowest Chronic Value for: } & \multirow[b]{2}{*}{$\begin{array}{l}\text { All Organ- } \\
\text { isms }\end{array}$} \\
\hline & Acute & Chronic & $\begin{array}{l}\text { Secondary } \\
\text { Acute } \\
\text { Value }\end{array}$ & $\begin{array}{l}\text { Secondary } \\
\text { Chronic } \\
\text { Value }\end{array}$ & & Daphnids & $\begin{array}{c}\text { Non- } \\
\text { Daphnid } \\
\text { Inverte- } \\
\text { brates } \\
\end{array}$ & $\begin{array}{l}\text { Aquatic } \\
\text { Plants }\end{array}$ & \\
\hline 2-Octanone & & & 150 & 8.3 & & & & & \\
\hline $\begin{array}{l}\text { PCBs total } \\
\text { Aroclor@ } 1221\end{array}$ & 2.0 & & 5.0 & $\begin{array}{l}0.14^{\mathrm{b}} \\
0.28\end{array}$ & $\begin{array}{l}0.2 \\
* 60\end{array}$ & 2.1 & 0.8 & 0.144 & $\begin{array}{l}0.1 \\
* 60\end{array}$ \\
\hline Aroclor@ 1232 & & & 10 & 0.58 & $* 124$ & & & - & $* 124$ \\
\hline Aroclor@ 1242 & & & 1.2 & 0.053 & 9.00 & & 4.9 & 300 & 4.9 \\
\hline Aroclor(\$ 1248 & & & 1.4 & 0.081 & & & & - & \\
\hline Aroclor@ 1254 & & & 0.60 & 0.033 & & 2.9 & & 0.1 & 0.1 \\
\hline Aroclor 1260 & & & 1,700 & 94 & $<1.3$ & & & - & 2.3 \\
\hline Pentachlorobenzene & & & $8.4^{r}$ & $0.47^{r}$ & & & & & \\
\hline 1-Pentanol & & & 2,000 & 110 & $* 30,493$ & & & & $* 30,493$ \\
\hline Phenanthrene & $30^{\circ}$ & $6.3^{e}$ & & & & 200 & & & 200 \\
\hline Phenol & $3,600^{3}$ & $110^{8}$ & & & $<200$ & $* 2,005$ & & 20,000 & $<200$ \\
\hline 2-Propanol & & & 130 & 7.5 & *590 & & & & $* 590$ \\
\hline $1,1,2,2$ Tetrachloroethane & & & 2,100 & 610 & 2,400 & 9,900 & & 136,000 & 2,400 \\
\hline Tetrachloroethene & & & 830 & 98 & 840 & 750 & & $>816,000$ & 750 \\
\hline Tetrachloromethane & & & $4,400^{r}$ & $240^{t}$ & & & & & \\
\hline Toluene & & & 120 & 9.8 & $* 1,269$ & $* 25,229$ & & 245,000 & $* 1,269$ \\
\hline Tribromomethane & & & $2,300^{\prime}$ & $320^{r}$ & & & & & \\
\hline 1,2,4-Trichlorobenzene & & & $700^{r}$ & $110^{r}$ & & & & & \\
\hline 1,1,1-Trichlorocthane & & & 200 & 11 & $* 3,493$ & & & $>669,000$ & $* 3,493$ \\
\hline 1,1,2-Trichloroethane & & & 5,200 & 1,200 & 9,400 & 18,400 & & & 9,400 \\
\hline Trichloroethene & & & 440 & 47 & 11,100 & $* 7,257$ & & & $* 7,257$ \\
\hline Vinyl acetate & & & 280 & 16 & $* 810$ & & & & $* 810$ \\
\hline
\end{tabular}


Table 1. (continued)

\begin{tabular}{|c|c|c|c|c|c|c|c|c|c|}
\hline \multirow{2}{*}{ Chemical } & \multicolumn{2}{|c|}{ NAWQ Criteria } & \multicolumn{2}{|c|}{ Tier II Values } & \multicolumn{5}{|c|}{ Lowest Chronic Value for: } \\
\hline & Acute & Chronic & $\begin{array}{c}\text { Secondary } \\
\text { Acute } \\
\text { Value }\end{array}$ & $\begin{array}{c}\text { Secondary } \\
\text { Chronic } \\
\text { Valuc }\end{array}$ & Fish & Daphnids & $\begin{array}{c}\text { Non- } \\
\text { Daphnid } \\
\text { Inverte- } \\
\text { brates }\end{array}$ & $\begin{array}{l}\text { Aquatic } \\
\text { Plants }\end{array}$ & $\begin{array}{l}\text { All Organ- } \\
\text { isms }\end{array}$ \\
\hline Xylene & & & 230 & 13 & $* 62,308$ & & & & $* 62,308$ \\
\hline$m$-Xylene & & & $32^{t}$ & $1.8^{f}$ & & & & & \\
\hline
\end{tabular}

Notes:

+ Hardness dependent criterion normalized to $100 \mathrm{mg} / \mathrm{L}$

* Numbers preceded by * are estimates. Methods of estimation are described in the text.

a The chronic NAWQC for chlordane $(0.0043 \mu \mathrm{g} / \mathrm{L})$ and mercury $(0.012 \mu \mathrm{g} / \mathrm{L})$, are based on the final residue values. FCVs are used as benchmarks to protect aquatic life.

b The chronic NAWQC for DDT $(0.001 \mu \mathrm{g} / \mathrm{L})$, total PCBs $(0.014 \mu \mathrm{g} / \mathrm{L})$, and heptachlor $(0.0038 \mu \mathrm{g} / \mathrm{l})$ are is based on the final residue values; for benchmarks to protect aquatic life, we use SCVs.

- The CV for DDT in Jarvinen et al. 1977 of $0.9 \mu \mathrm{g} / \mathrm{l}$ is the arithmetic mean of the NOEC and LOEC. We used the geometric mean which is 0.73 .

d For fish di-n-butyl phthalate lowest CV, the geometric mean of the measured concentrations for the NOEC and LOEC rather than the nominal concentrations used by the authors (McCarthy and Whitmore 1985) was used herein.

c These numbers are Final Acute Values and Final Chronic Values calculated by the EPA for use in the derivation of sediment quality criteria (EPA 1993b).

r Values calculated for OSWER (1996).

B Values calculated by the Great Lakes Water Quality Initiative (EPA 1993d).

h SAV was calculated by the Great Lakes Water Quality Initiative because some data used to derive FAV were questionable (EPA 1992).

I These values are draft FAV and FCV values (EPA 1988b). 
Table 2. Summary of alternative benchmarks for priority contaminants in fresh water based on levels of chronic effects (all values in micrograms per liter)

\begin{tabular}{|c|c|c|c|c|}
\hline \multirow{2}{*}{ Chemical } & \multicolumn{2}{|c|}{ Lowest Test $\mathbf{E C}_{20}$ for: } & \multirow{2}{*}{$\begin{array}{c}\text { Sensitive } \\
\text { Species Test } \\
\text { EC }_{20}\end{array}$} & \multirow{2}{*}{$\begin{array}{c}\text { Population } \\
\text { EC }_{20}\end{array}$} \\
\hline & Fish & Daphnids & & \\
\hline Aluminum & 4,700 & 540 & 75 & \\
\hline Antimony & 2,310 & 1,900 & & 79 \\
\hline Arsenic III & 2,130 & 633 & 55 & 1,995 \\
\hline Arsenic V & 1,500 & $>932$ & & 185 \\
\hline \multicolumn{5}{|l|}{ Barium } \\
\hline Beryllium & *148 & 3.8 & & 21 \\
\hline Boron & & 7,000 & & \\
\hline Cadmium & 1.8 & 0.75 & $0.013^{\mathrm{s}}$ & 4.3 \\
\hline \multicolumn{5}{|l|}{ Calcium } \\
\hline Chromium III & 89 & & 8.44 & 126 \\
\hline Chromium VI & 51 & 0.5 & 0.266 & 316 \\
\hline Cobalt & 810 & $<4.4$ & & 3.98 \\
\hline Copper & 5 & 0.205 & 0.26 & 8.6 \\
\hline Cyanide & 5.3 & & 1.17 & 11 \\
\hline Fluorine & $* 5,336$ & 3,706 & & 1,080 \\
\hline Iron & & 16 & & \\
\hline Lead & 22 & & 0.35 & 71 \\
\hline \multicolumn{5}{|l|}{ Magnesium } \\
\hline Manganese & 1,270 & $<1,100$ & & 112 \\
\hline Mercury, inorganic & 0.87 & 0.87 & 0.18 & 0.32 \\
\hline Mercury, methyl & $<0.03$ & 0.87 & & 0.28 \\
\hline Molybdenum & & 360 & & \\
\hline Nickel & 62 & 45 & $11^{2}$ & 215 \\
\hline \multicolumn{5}{|l|}{ Potassium } \\
\hline Selenium & 40 & 25 & 2.60 & \\
\hline Silver & 0.20 & $<0.56$ & $0.14^{a}$ & 0.32 \\
\hline \multicolumn{5}{|l|}{ Sodium } \\
\hline \multicolumn{5}{|l|}{ Strontium } \\
\hline Thallium & 81 & 64 & & 67 \\
\hline
\end{tabular}


10

Table 2. (continued)

\begin{tabular}{|c|c|c|c|c|}
\hline \multirow[b]{2}{*}{ Chemical } & \multicolumn{2}{|c|}{ Lowest Test $\mathbf{E C}_{\mathbf{2 0}}$ for: } & \multirow{2}{*}{$\begin{array}{c}\text { Sensitive } \\
\text { Species Test } \\
\text { EC }_{\mathbf{2 0}}\end{array}$} & \multirow{2}{*}{$\begin{array}{l}\text { Population } \\
\text { EC }_{20}\end{array}$} \\
\hline & Fish & Daphnids & & \\
\hline \multicolumn{5}{|l|}{ Tin } \\
\hline Uranium & *455 & & & 27 \\
\hline Vanadium & 41 & 430 & & 32 \\
\hline Zinc & 47 & & 21 & 80 \\
\hline Zirconium & $* 2,396$ & & & 251 \\
\hline \multicolumn{5}{|c|}{ Organics } \\
\hline Acenaphthene & $<197$ & & & \\
\hline Acetone & *161,867 & & & 23,714 \\
\hline Anthracene & $* 0.35$ & $>8.2$ & & \\
\hline Benzene & 21 & & & 229 \\
\hline Benzidene & *158 & & & 68 \\
\hline \multicolumn{5}{|l|}{ Benzo(a)anthracene } \\
\hline Benzo(a)pyrene & $>2.99$ & & & \\
\hline Benzoic acid & $* 7,409$ & & & 1,259 \\
\hline Benzyl alcohol & $* 550$ & & & 375 \\
\hline BHC (lindane) & $<1.1$ & 11 & 0.11 & \\
\hline \multicolumn{5}{|l|}{ BHC (other) } \\
\hline Bis(2-ethylhexyl)phthalate & $>54$ & $<3$ & & 50 \\
\hline 2-Butanone & $* 98,772$ & & & 17,783 \\
\hline Carbon disulfide & *5719 & & & 1,000 \\
\hline Carbon tetrachloride & 65 & & & 224 \\
\hline Chlordane & $<0.25$ & 12.1 & 0.50 & 0.71 \\
\hline Chlorobenzene & 1,002 & & & 165 \\
\hline \multicolumn{5}{|l|}{ Chloroethane } \\
\hline Chloroform & 8,400 & & & 562 \\
\hline DDD p,p' & $* 3.99$ & & & 0.61 \\
\hline $\mathrm{DDT}$ & 0.35 & & 0.008 & \\
\hline
\end{tabular}


11

Table 2. (continued)

\begin{tabular}{|c|c|c|c|c|}
\hline \multirow[b]{2}{*}{ Chemical } & \multicolumn{2}{|c|}{ Lowest Test $\mathrm{EC}_{20}$ for: } & \multirow{2}{*}{$\begin{array}{c}\text { Sensitive } \\
\text { Species Test } \\
\text { EC }_{\mathbf{2 0}}\end{array}$} & \multirow{2}{*}{$\begin{array}{l}\text { Population } \\
\text { EC }_{20}\end{array}$} \\
\hline & Fish & Daphnids & & \\
\hline Di-n-butyl phthalate & 270 & 500 & & 251 \\
\hline \multicolumn{5}{|l|}{ Dibenzofuran } \\
\hline 1,1-Dichloroethane & $* 8,219$ & & & 1,585 \\
\hline 1,2-Dichloroethane & 29,000 & $<11,000$ & & 1,259 \\
\hline 1,1-Dichloroethene & & & & 447 \\
\hline 1,2-Dichloroethenes & $* 5,719$ & & & \\
\hline 1,3-Dichloropropene & *350 & & & 40 \\
\hline Diethyl phthalate & & & & 1,000 \\
\hline Di-n-octyl phthalate & $<100$ & 310 & & 1,995 \\
\hline Ethyl benzene & & & & 398 \\
\hline Fluoranthene & & & & 32 \\
\hline Heptachlor & 0.86 & & 0.004 & 0.1 \\
\hline Hexane & $* 28,995$ & & & \\
\hline 2-Hexanone & $* 16,155$ & & & 1,259 \\
\hline 1-Methylnaphthalene & $* 500$ & & & 31.62 \\
\hline 4-Methyl-2-pentanone & & & & 1,585 \\
\hline 2-Methylphenol & $* 470$ & & & 74 \\
\hline Methylene chloride & 410 & & & 1,259 \\
\hline Naphthalene & 450 & $>600$ & & 1,000 \\
\hline 4-Nitrophenols & $* 464$ & 5,000 & & 60 \\
\hline $\mathrm{N}$-Nitrosodiphenylamine & *339 & & & 40 \\
\hline 3-Octanone & *3571 & & & \\
\hline $\begin{array}{l}\text { PCBs total } \\
\text { Aroclor@ } 1221\end{array}$ & $\begin{array}{l}0.4 \\
* 80\end{array}$ & 1.2 & & $\begin{array}{c}0.63 \\
10\end{array}$ \\
\hline Aroclor@ 1232 & $* 148$ & & & 16 \\
\hline Aroclor@ 1242 & $<2.9$ & & & 1.58 \\
\hline Aroclor(B 1248 & 0.4 & 2.5 & & 1.26 \\
\hline Aroclor@ 1254 & 0.52 & 1.2 & & 0.63 \\
\hline Aroclor@ 1260 & 2.1 & & & 316 \\
\hline 1-Pentanol & $* 15,200$ & & & 3,548 \\
\hline
\end{tabular}


Table 2. (continued)

\begin{tabular}{|c|c|c|c|c|}
\hline \multirow{2}{*}{ Chemical } & \multicolumn{2}{|c|}{ Lowest Test $\mathbf{E C}_{\mathbf{2 0}}$ for: } & \multirow{2}{*}{$\begin{array}{c}\text { Sensitive } \\
\text { Species Test } \\
\text { EC }_{\mathbf{2 0}}\end{array}$} & \multirow{2}{*}{$\begin{array}{c}\text { Population } \\
\mathbf{E C}_{20}\end{array}$} \\
\hline & Fish & Daphnids & & \\
\hline Phenanthrene & & 110 & & \\
\hline Phenol & $<230$ & & & 4,467 \\
\hline 2-Propanol & $* 35,381$ & & & 3,162 \\
\hline 1,1,2,2-Tetrachloroethane & 1,400 & $<420$ & . & 1,585 \\
\hline Tetrachloroethẹne & 500 & 510 & & 50 \\
\hline Toluene & $<26$ & & & 200 \\
\hline 1,1,1-Trichloroethane & $* 2,457$ & 1,300 & & 251 \\
\hline 1,1,2-Trichloroethane & 14,800 & 13,000 & & 15,849 \\
\hline Trichloroethene & 5758 & & & 232 \\
\hline Vinyl acetate & $* 718$ & & & 108 \\
\hline Xylene & 2680 & & & \\
\hline
\end{tabular}

Notes:

* Numbers preceded by * are estimates. Methods of estimation are described in the text.

- Study LC50's were used rather than species mean LC50s so water hardness would correspond to EC20 values.

ratios from tests of different families of aquatic organisms (Stephan et al. 1985). It is intended to prevent significant toxic effects in chronic exposures and is used in this assessment as one possible lower screening benchmark. The NAWQC are listed in Table 1.

NAWQC for several metals are functions of water hardness; the criteria are lower for lower hardness levels. The criteria for $100 \mathrm{mg} / \mathrm{L}$ hardness as reported by the EPA are presented in this report. That hardness is near the lower end of the range of hardness values reported for the Oak Ridge Reservation, so it is moderately conservative. For sites with different water hardnesses, site-specific criteria should be calculated. The formulas for hardness correction are listed in the discussions of individual chemicals.

Many readers will note that the EPA's compilations of NAWQC contain values for many chemicals that have no NAWQC listed herein (EPA 1986b); the EPA lists lowest CVs for those chemicals for which there is not enough data to calculate a criterion but for which there is at least one CV. Lowest CVs are treated as a separate category of benchmarks in this compilation.

Some chronic NAWQC are based on protection of humans or other piscivorous organisms rather than protection of aquatic organisms. Those criteria are not included herein because screening for risks to wildlife or humans is performed by other methods. However, if sufficient data were available to calculate a final chronic value (FCV) for those chemicals, then the FCV are presented in place of the chronic NAWQC in Table 1 , and its derivation is noted.

For particular chemicals, the lower screening benchmark could be lower than the chronic NAWQC for any one of the following reasons. First, the chronic NAWQC are based on a threshold for statistical significance rather than biological significance. In some chronic tests, because of highly variable results, the statistical threshold corresponds to greater than $50 \%$ effect on a response 
parameter (Stephan and Rogers 1985, Suter et al. 1987). Second, not all important responses are included in the subchronic toxicity tests that are used to calculate many chronic NAWQC. In particular, effects on fecundity, which is the most sensitive response parameter on average in fish toxicity tests (Suter et al. 1987), are often not included. Third, the chronic NAWQC are based on the most statistically sensitive of the measured response parameters in each chronic or subchronic test. Therefore, cumulative effects over the lifecycle of fish and invertebrates are not considered. Fourth, the NAWQC are set at a level that protects "most species most of the time." Finally, many of the NAWQC have not been revised since 1980 so they do not incorporate recent data that are included in the calculation of other benchmarks. These concerns are supported by the recent finding that nickel concentrations (on the Oak Ridge Reservation) that are below chronic NAWQC are nonetheless toxic to daphnids (Kszos et al. 1992).

\subsection{TIER II VALUES}

If NAWQC were not available for a chemical, the Tier II method described in the EPA's Proposed Water Quality Guidance for the Great Lakes System was applied (EPA 1993a). Tier II values were developed so that aquatic benchmarks could be established with fewer data than are required for the NAWQC. The Tier II values are concentrations that would be expected to be higher than NAWQC in no more than $20 \%$ of cases. Tier II values calculated by the EPA are listed in Table 1, and the sources are cited. Other Tier II values are derived as described in the following text.

The Tier II values equivalent to the FAV and FCV are the Secondary Acute Values (SAVs) and Secondary Chronic Values (SCVs), respectively. The sources of data for the Tier II values are listed in Appendix A, and the procedure and factors used to calculate the SACs and SCVs are in Appendix B. The methods described herein differ from EPA's (1993a) in one respect. The Great Lakes SAVs require an LC50 for a daphnid, but that requirement would severely restrict the number of benchmarks that could be calculated. The EPA has provided factors for calculating SAVs when no daphnid LC50s are available, and these.factors are used herein (Stephan 1991).

Some of the SAVs and SCVs presented in this report differ from those presented in the prior edition (Suter and Mabrey 1994) for three reasons. First, in the previous report we included all data that occurred in EPA water quality criteria documents. However, much of the data included in criteria documents issued prior to 1985 are no longer considered acceptable by the EPA. Second, some data from the EPA's AQUIRE data set were used by Suter and Mabrey (1994) that appeared to be acceptable based on the information provided in the data base and the EPA's rating of the data. It has become clear that much of that data would not be acceptable to the EPA for calculating criteria. Therefore, we obtained all original publications and independently reviewed them against the criteria in Stephan et al. (1985). Those criteria are summarized in Appendix B. Finally, some new data have been found and incorporated.

Only high quality standard data are used in this document if such values are available for a chemical. That is, if even one test that meets the criteria in Stephan et al (1985) was found, all nonconforming tests were excluded. However, when no such values are available, nonstandard or lower quality test results which were judged by the authors to be reliable were used. Values derived using data that did not meet the Stephan et al. (1985) criteria are noted. 


\subsection{LOWEST CHRONIC VALUES}

The lowest chronic values for fish and invertebrates reported in the literature are potential lower benchmarks. Chronic values are used to calculate the chronic NAWQC, but the lowest chronic value may be lower than the chronic NAWQC. Because of the short generation time of algae and the relative lack of standard chronic tests for aquatic plants, EPA guidelines are followed in using any algal test of at least 96-hour duration and any biologically meaningful response for the plant values.

\subsection{ESTIMATED LOWEST CHRONIC VALUES}

Estimated lowest chronic values for fish and invertebrates are another set of potential lower benchmarks. Estimated chronic values were extrapolated from 96-hour LC50s using equations from Suter et al. (1987) and Suter (1993). The equations are as follows where LC50 equals the lowest species mean 96-hour LC50 for fish and 48-hour EC50 for daphnids, and CV equals the estimated chronic value for that taxon. The $95 \%$ prediction interval at the mean is $\log \mathrm{CV} \pm$ the $\mathrm{PI}$ value $(95 \%$ prediction intervals contain $95 \%$ of observations versus $95 \%$ confidence intervals which contain the mean with $95 \%$ confidence).

Fish CV for a metallic contaminant:

$$
\begin{gathered}
\log C V=0.73 \log L C 50-0.70 \\
P I=1.2
\end{gathered}
$$

Fish CV for a nonmetallic contaminant:

$$
\begin{gathered}
\log C V=1.07 \log L C 50-1.51 \\
\text { PI }=1.5
\end{gathered}
$$

Daphnid CV for a metallic contaminant:

$$
\begin{gathered}
\log C V=0.96 \log \mathrm{LC} 50-1.08 \\
P I=1.56
\end{gathered}
$$

Daphnid CV for a nonmetallic contaminant:

$$
\begin{gathered}
\log C V=1.11 \log L C 50-1.30 \\
P I=1.35
\end{gathered}
$$

\subsection{TEST EC20s}

Another potential lower benchmark is the test EC20 for fish, which is defined as the highest tested concentration causing less than $20 \%$ reduction in (1) the weight of young fish per initial female fish in a lifecycle or partial life-cycle test or (2) the weight of young per egg in an early life-stage test. A similar potential lower benchmark is the test EC20 for daphnids, which is the highest tested concentration causing less than $20 \%$ reduction in the product of growth, fecundity, and survivorship in a chronic test with a daphnid species. (Daphnids include members of the genera Daphnia, Ceriodaphnia, and Simocephalus.) These benchmarks are intended to be indices of population production. They are equivalent to chronic values in that they are simply a summary of the results of chronic toxicity tests, and in most cases the same test supplied the lowest chronic value and the lowest test EC20. However, the test EC20s are based on a level of biological effect rather than a level of statistical significance, and they integrate all of the stages of the toxicity test rather than treating each response independently. The $20 \%$ figure was chosen as approximately the mean level of effect on 
individual response parameters observed at CVs and as a minimum detectable difference in population characteristics in the field (Suter et al. 1987, 1992). These values are listed in Table 2.

\subsection{ESTIMATED TEST EC20s}

The estimated test EC20 is another potential benchmark. The estimated values were extrapolated from 96-hour LC50 values using equations from Suter (1992). The equation for the lowest fish test EC20 is as follows where LC50 equals the lowest species mean 96-hour LC50 for fish, and the EC25 for weight of juveniles per egg is used as an estimate of the test EC20 value. (The difference between $20 \%$ and $25 \%$ effect is trivial given the uncertainties in these estimates and the steepness of the concentration-response curves.) The log-scaled 95\% prediction interval at the mean is log EC25 \pm the PI value:

$$
\begin{aligned}
\log \mathrm{EC} 25= & 0.90 \log \mathrm{LC} 50-0.86 \\
& \mathrm{PI}=1.6
\end{aligned}
$$

These values are listed in Table 2 for those chemicals that have no empirical test EC20.

\subsection{SENSITIVE SPECIES TEST EC20s}

The sixth potential benchmark is the EC20, adjusted to approximate the fifth percentile of the species sensitivity distribution. It is calculated in the same way as the chronic NAWQC except that the test EC20s are used in place of CVs, and salt water species were not included. The FAV for each of the criterion chemicals was divided by the geometric mean of ratios of LC50s to EC20s. These benchmarks are referred to as sensitive species (SS) test EC20s, and are listed in Table 2.

\subsection{POPULATION EC25s}

The last potential benchmark is an estimate of the continuous concentration that would cause a $20 \%$ reduction in the recruit abundance of largemouth bass. The method used was described by Barnthouse et al. (1990) and is briefly summarized herein. The recruit abundance estimates are generated by a matrix model of a reservoir largemouth bass population (Bartell 1990). The fecundity, hatching success, larval survival, and post-larval survival of the model population are each decremented by a value generated from statistical extrapolation models. For each life stage for which a concentration-response relationship could be calculated, that relationship was adjusted for the relative sensitivity of the test species and the bass. For those life stages with no concentrationresponse relationship, the relationship was estimated using life stage to life stage extrapolation models, and the taxonomic adjustment was made. However, if the authors of the study reported that life stage was unaffected, the decrement for that life stage was set to zero. If no chronic test data were available, extrapolations from LC50s to chronic responses of each life stage were performed. Uncertainties in all of these extrapolations were propagated through the models to generate estimates of uncertainty. For each chemical, each available freshwater fish chronic test was used to parameterize a model run. If no chronic test data were available, each available freshwater fish LC50 was used to parameterize a model run. The results are presented in Appendix C. The geometric mean of all population EC25 estimates for each chemical is reported in Table 2. 


\subsection{ECOTOX THRESHOLDS}

The EPA's OSWER has published Ecotox Thresholds (ETs) which are intended to be used for screening contaminants at Comprehensive Environmental Response, Compensation, and Liability Act (CERCLA) sites (OSWER 1996); these values are available for 20 metals and 47 organics in fresh water and for 10 metals and 7 organics in marine waters. The fresh water values are presented in Table 3. Their derivation is briefly explained in the following text.

In general, chronic NAWQC values are preferred as aqueous ETs. However, as with the benchmarks in Table 1, criteria that are based on fish consumption rather than aquatic toxic effects (DDT, heptachlor, and toxaphene) are not used. Tier II values are presented in their place. For diazinon, the FCV calculated by the Great Lakes Water Quality Initiative (GLWQ1) was used as a criterion value (EPA 1992).

OSWER recommends the use of dissolved concentrations of metals. Therefore, the method described in Prothro (1993) is used to correct for dissolved phase concentrations, which causes some of the metals criteria values used as ETs to differ slightly from the criteria listed in Table 1 or in the Region IV values.

SCVs are used when NAWQCs are not available. Four of these SCVs are from the GLWQI (EPA 1992), 34 are from the prior edition of this document (Suter and Mabrey 1994), and 18 were calculated by OSWER (1996). Three chemicals with OSWER-derived SCVs (endosulfan, methoxyclor, and malathion) had NAWQCs, but the criteria were judged to be old and unreliable. Tier II values were not derived if no daphnia acute values were available.

\subsection{REGION IV SCREENING VALUES}

EPA Region IV has published acute and chronic ecological screening values (SVs) for fresh surface water (Waste Management Division 1995); they are presented in Table 3. The acute SVs consist of acute NAWQCs or, for chemicals with no acute NAWQC, of lowest acute LC50 or EC50 values divided by 10 . The chronic SVs consist of chronic NAWQCs or, for chemicals with no chronic NAWQC, of lowest CVs divided by 10 . If there were no CVs, the acute SV is divided by 10 to obtain the chronic SV. These divisions by 10 serve the same purpose as the models used to calculate Tier II values, but without the scientific or statistical basis and without using the full available data set. For some chemicals, the SVs are based on effects on fish eaters or irrigated plants rather than aquatic life. Region IV acknowledges that other values have greater ecological relevance (Waste Management Division 1995). As explained previously, there are separate benclumarks to address effects on plants and wildlife and an entirely separate set of risk assessment methods to protect humans who eat fish. Finally, the hardness dependent criteria are adjusted to $50 \mathrm{mg} / \mathrm{L}$ which is unrealistically low for the Oak Ridge Reservation and most other sites.

\subsection{BACKGROUND CONCENTRATIONS}

Background water concentrations should be used as a check for these benchmarks. That is, because some of these benchmarks are quite conservative and because the measured concentrations in ambient water may include forms that are not bioavailable, benchmark concentrations may be lower than background water concentrations. If the background concentrations are valid and represent an uncontaminated state and if exposed site does not contain forms of the chemicals that are more 
bioavailable or toxic than the forms at background sites, then screening benchmarks lower than the background concentration should not be used.

Table 3. Summary of OSWER threshold values for aquatic life (EPA 1996) and Region IV screening values for freshwater surface water (Region IV 1995) (All values are $\mu \mathrm{g} / \mathrm{L}$ )

\begin{tabular}{|c|c|c|c|c|}
\hline \multirow[b]{2}{*}{ Chemical } & \multicolumn{2}{|c|}{ OSWER Values } & \multicolumn{2}{|c|}{ Region IV Values $^{3}$} \\
\hline & $\begin{array}{l}\text { NAWQC } \\
\text { or FCV }\end{array}$ & Tier $\Pi^{2}$ & $\begin{array}{l}\text { Acute } \\
\text { Screening } \\
\text { Values } \\
\end{array}$ & $\begin{array}{l}\text { Chronic Screening } \\
\text { Values }\end{array}$ \\
\hline \multicolumn{5}{|c|}{ Metals } \\
\hline Aluminum & & & 750 & 87 \\
\hline Antimony & & & $1300(2 s)$ & $160(2 s)$ \\
\hline Arsenic III & 190 & & 360 & 190 \\
\hline Arsenic V & & $8.1 *$ & & \\
\hline Barium & & $3.9 *$ & & \\
\hline Beryllium & & $5.1 *$ & $16(6 s)$ & 053 (1s) \\
\hline Boron & & & - & $750^{4}$ \\
\hline Cadmium & $1.0 \mathrm{~h}$ & & $1.79 \mathrm{~h}$ & $0.66 \mathrm{~h}$ \\
\hline Chromium III & $180 \mathrm{~h}$ & & $984.32 \mathrm{~h}$ & $117.32 \mathrm{~h}$ \\
\hline Chromium VI & 10 & & 16 & 11 \\
\hline Cobalt & & $3.0 *$ & & \\
\hline Copper & $11 \mathrm{~h}$ & & $9.22 \mathrm{~h}$ & $6.54 \mathrm{~h}$ \\
\hline Iron & 1000 & & - & 1000 \\
\hline Lead & $2.5 \mathrm{~h}$ & & 33.78 & 1.32 \\
\hline Manganese & & $80 *$ & & \\
\hline Mercury & & & 2.40 & 0.0123 \\
\hline Mercury, inorganic & 1.3 & & & \\
\hline Mercury, methyl & & $0.003 *$ & & \\
\hline Molybdenum & & $240 *$ & & \\
\hline Nickel & $160 \mathrm{~h}$ & & $789.00 \mathrm{~h}$ & $87.71 \mathrm{~h}$ \\
\hline Selenium & 5.0 & & 20.00 & 5.00 \\
\hline Silver & & & $1.23 \mathrm{~h}$ & $0.012(1 \mathrm{~s})$ \\
\hline Thallium & & & $140.00(3 \mathrm{~s})$ & $4.00(2 s)$ \\
\hline
\end{tabular}


Table 3. (continued)

\begin{tabular}{|c|c|c|c|c|}
\hline \multirow[b]{2}{*}{ Chemical } & \multicolumn{2}{|c|}{ OSWER Values } & \multicolumn{2}{|c|}{ Region IV Values $^{3}$} \\
\hline & $\begin{array}{l}\text { NAWQC } \\
\text { or FCV }\end{array}$ & Tier $\mathbf{I}^{2}$ & $\begin{array}{l}\text { Acute } \\
\text { Screening } \\
\text { Values }\end{array}$ & $\begin{array}{l}\text { Chronic Screening } \\
\text { Values }\end{array}$ \\
\hline Vanadium & & $19 *$ & & \\
\hline Zinc & $100 \mathrm{~h}$ & & $65.04 \mathrm{~h}$ & $58.91 \mathrm{~h}$ \\
\hline \multicolumn{5}{|c|}{ Organic Compounds } \\
\hline Acenaphthene & $23 \mathrm{~S}$ & & $170(2 s)$ & 17 \\
\hline Acrolein & & & $6.8(3 \mathrm{~s})$ & $2.1(1 \mathrm{~s})$ \\
\hline Acrylonitrile & & & $755(4 s)$ & 75.5 \\
\hline Aldrin & & & 3 & 0.3 \\
\hline Benzene & & $46 *$ & $530(7 \mathrm{~s})$ & 53 \\
\hline Benzidine & & & $250(4 s)$ & 25 \\
\hline Benzo(a)pyrene & & $0.014 *$ & & \\
\hline $\mathrm{a}-\mathrm{BHC}$ & & & - & $500^{6}$ \\
\hline b-BHC & & & - & $5000^{6}$ \\
\hline g-BHC (Lindane) & 0.08 & & 2 & 0.08 \\
\hline Biphenyl & & $14 \#$ & & \\
\hline Bis(2-chloroethyl) ether & & & $23800(1 \mathrm{~s})$ & 2380 \\
\hline Bis(2-ethylhexyl)phthalate & & $32 *$ & $1110(2 \mathrm{~s})$ & $<0.3(2 \mathrm{~s})$ \\
\hline Bromoform & & & $2930(2 s)$ & 293 \\
\hline 4-Bromophenylphenyl ether & & $1.5 \#$ & & \\
\hline $\begin{array}{l}\text { 4- Bromophenylphenyl } \\
\text { phthalate }\end{array}$ & & & $36(2 \mathrm{~s})$ & $12.2(1 \mathrm{~s})$ \\
\hline Butylbenzyl phthalate & & $19 \#$ & $330(4 s)$ & $22(2 s)$ \\
\hline Carbon tetrachloride & & & $3520(3 \mathrm{~s})$ & 352 \\
\hline Chlordane & & & 2.4 & $0.0043^{5}$ \\
\hline Chlorobenzene & & $130 *$ & $1950(5 s)$ & 195 \\
\hline 2-Chloroethylvinyl ether & & & $35400(1 \mathrm{~s})$ & 3540 \\
\hline Chloroform & & & $2890(3 s)$ & 289 \\
\hline 2-Chlorophenol & & & $438(5 s)$ & 43.8 \\
\hline Chloropyrifos & & & 0.083 & 0.041 \\
\hline
\end{tabular}


19

Table 3. (continued)

\begin{tabular}{|c|c|c|c|c|}
\hline \multirow[b]{2}{*}{ Chemical } & \multicolumn{2}{|c|}{ OSWER Values } & \multicolumn{2}{|c|}{ Region IV Values $^{3}$} \\
\hline & $\begin{array}{l}\text { NAWQC } \\
\text { or FCV }\end{array}$ & Tier $\mathbf{I}^{2}$ & $\begin{array}{l}\text { Acute } \\
\text { Screening } \\
\text { Values }\end{array}$ & $\begin{array}{l}\text { Chronic Screening } \\
\text { Values }\end{array}$ \\
\hline 4,4'-DDT & & $0.013+$ & 1.1 & 0.001 \\
\hline 4,4'-DDE & & & $105(1 \mathrm{~s})$ & 10.5 \\
\hline 4,4'-DDD & & & $0.064(8 \mathrm{~s})$ & 0.0064 \\
\hline Demeton & & & - & 0.1 \\
\hline Diazinon & $0.043 \mathrm{~F}$ & & & \\
\hline Dibenzofuran & & 20 * & & \\
\hline 1,2-Dichlorobenzene & & $14 \#$ & $158(4 s)$ & $15.8(3 \mathrm{~s})$ \\
\hline 1,3-Dichlorobenzene & & $71 \#$ & $502(3 \mathrm{~s})$ & 50.2 \\
\hline 1,4-Dichlorobenzene & & $15 \#$ & $112(5 \mathrm{~s})$ & 11.2 \\
\hline 1,1-Dichloroethane & & $47 *$ & & \\
\hline 1,2-Dichloroethane & & & $11800(3 s)$ & $2000(1 \mathrm{~s})$ \\
\hline 1,1-Dichloroethylene & & & $3030(3 \mathrm{~s})$ & 303 \\
\hline 2,4-Dichlorophenol & & & $202(3 s)$ & $36.5(1 \mathrm{~s})$ \\
\hline 1,2-Dichloropropane & & & $5250(3 s)$ & 525 \\
\hline $\begin{array}{l}\text { Dichloropropylene (cis and } \\
\text { trans) }\end{array}$ & & & $606(2 s)$ & $24.4(1 \mathrm{~s})$ \\
\hline Dieldrin & $0.062 \mathrm{~S}$ & & 2.5 & $0.0019^{5}$ \\
\hline Diethyl phthalate & & $220 *$ & $5210(2 \mathrm{~s})$ & 521 \\
\hline 2,4-Dimethylphenol & & & $212(3 s)$ & 21.2 \\
\hline Dimethyl phthalate & & & $3300(2 s)$ & 330 \\
\hline Di-n-butyl phthalate & & $33 *$ & $94(6 s)$ & 9.4 \\
\hline 2,4-Dinitrophenol & & & $62(3 \mathrm{~s})$ & 6.2 \\
\hline 2,4-Dinitrotoluene & & & $3100(2 s)$ & 310 \\
\hline Dioxin $(2,3,7,8-T C D D)$ & & & 0.1 & $0.00001^{5}$ \\
\hline 1,2-Diphenylhydrazine & & & $27(2 s)$ & 2.7 \\
\hline Endosulfan, mixed isomers & & $0.051 \#$ & & \\
\hline Endosulfan, alpha & & $0.051 \#$ & 0.22 & 0.056 \\
\hline Endosulfan, beta & & $0.051 \#$ & 0.22 & 0.056 \\
\hline
\end{tabular}


20

Table 3. (continued)

\begin{tabular}{|c|c|c|c|c|}
\hline \multirow[b]{2}{*}{ Chemical } & \multicolumn{2}{|c|}{ OSWER Values } & \multicolumn{2}{|c|}{ Region IV Values ${ }^{3}$} \\
\hline & $\begin{array}{l}\text { NAWQC } \\
\text { or FCV }\end{array}$ & Tier $\mathbb{I}^{2}$ & $\begin{array}{l}\text { Acute } \\
\text { Screening } \\
\text { Values }\end{array}$ & $\begin{array}{l}\text { Chronic Screening } \\
\text { Values }\end{array}$ \\
\hline Endrin & $0.061 \mathrm{~S}$ & & 0.18 & $0.0023^{5}$ \\
\hline Ethylbenzene & & $290 *$ & $4530(5 s)$ & 453 \\
\hline Fluoranthene & $8.1 \mathrm{~S}$ & & $398(2 s)$ & 39.8 \\
\hline Fluorene & & $3.9 \#$ & & \\
\hline Guthion & & & - & 0.01 \\
\hline Heptachlor & & $0.0069+$ & 0.52 & $0.0038^{5}$ \\
\hline Heptachlor epoxide & & & 0.52 & $0.0038^{5}$ \\
\hline Hexachlorobutadiene & & & $9(5 s)$ & $0.93(1 \mathrm{~s})$ \\
\hline Hexachlorocyclopentadiene & & & $0.7(4 \mathrm{~s})$ & 0.07 \\
\hline Hexachloroethane & & $12 \#$ & $98(5 s)$ & 9.8 \\
\hline Isophorone & & & $11700(2 \mathrm{~s})$ & 1170 \\
\hline Lindane (see g-BHC) & & & & \\
\hline Malathion & & 0.097 & - & 0.01 \\
\hline Methoxychlor & & $0.019 \#$ & - & 0.03 \\
\hline Methyl bromide & & & $1100(1 s)$ & 110 \\
\hline Methyl chloride & & & $55000(1 \mathrm{~s})$ & 5500 \\
\hline $\begin{array}{l}\text { 3-Methyl-4-chlorophenol } \\
\text { (p-Chloro-m-cresol) }\end{array}$ & & & $3(1 s)$ & 0.3 \\
\hline $\begin{array}{l}\text { 2-Methyl-4, 6-dinitrophenol } \\
\text { (4,6- Dinitro-o-cresol) }\end{array}$ & & & $23(4 s)$ & 2.3 \\
\hline Methylene chloride & & & $19300(3 s)$ & 1930 \\
\hline Mirex & & & - & 0.001 \\
\hline Naphthalene & & $24 *$ & $230(4 s)$ & $62(1 \mathrm{~s})$ \\
\hline Nitrobenzene & & & $2700(2 s)$ & 270 \\
\hline 2-Nitrophenol & & & - & 3500 \\
\hline 4-Nitrophenol & & & $828(3 s)$ & 82.8 \\
\hline $\mathrm{n}$-Nitrosodiphenylamine & & & $585(2 \mathrm{~s})$ & 58.5 \\
\hline Parathion & & & 0.065 & 0.013 \\
\hline
\end{tabular}


21

Table 3. (continued)

\begin{tabular}{|c|c|c|c|c|}
\hline \multirow[b]{2}{*}{ Chemical } & \multicolumn{2}{|c|}{ OSWER Values } & \multicolumn{2}{|c|}{ Region IV Values $^{3}$} \\
\hline & $\begin{array}{l}\text { NAWQC } \\
\text { or FCV }\end{array}$ & Tier $I^{2}$ & $\begin{array}{l}\text { Acute } \\
\text { Screening } \\
\text { Values } \\
\end{array}$ & $\begin{array}{l}\text { Chronic Screening } \\
\text { Values }\end{array}$ \\
\hline $\begin{array}{l}\text { PCB (total polychlorinated } \\
\text { biphenyls) }\end{array}$ & & 0.19 * & & \\
\hline PCB-1242 & & & $0.2(7 \mathrm{~s})$ & 0.014 \\
\hline PCB-1254 & & & $0.2(7 \mathrm{~s})$ & 0.014 \\
\hline PCB-1221 & & & $0.2(7 \mathrm{~s})$ & 0.014 \\
\hline PCB-1232 & & & $0.2(7 \mathrm{~s})$ & 0.014 \\
\hline PCB-1248 & & & $0.2(7 \mathrm{~s})$ & 0.014 \\
\hline PCB-1260 & & & $0.2(7 \mathrm{~s})$ & 0.014 \\
\hline PCB-1016 & & & $0.2(7 \mathrm{~s})$ & 0.014 \\
\hline Pentachlorobenzene & & $0.47 \#$ & 250 & 50 \\
\hline Pentachlorophenol & $13 \mathrm{pH}$ & & $20 \mathrm{pH}$ & $13 \mathrm{pH}$ \\
\hline Phenol & & & $1020(16 s)$ & $256(1 \mathrm{~s})$ \\
\hline \multicolumn{5}{|l|}{$\begin{array}{l}\text { Polynuclear aromatic } \\
\text { hydrocarbons }\end{array}$} \\
\hline Phenanthrene & $6.3 \mathrm{~S}$ & & & \\
\hline 1,2,4,5-Tetrachlorobenzene & & & 250 & 50 \\
\hline 1,1,2,2-Tetrachloroethane & & $420 *$ & $932(3 \mathrm{~s})$ & 240 (1s) \\
\hline Tetrachloroethylene & & $120 *$ & $528(5 s)$ & $84(1 \mathrm{~s})$ \\
\hline Tetrachloromethane & & $240 \#$ & & \\
\hline Toluene & & $130 *$ & $1750(5 \mathrm{~s})$ & 175 \\
\hline Toxaphene & & $0.011 \#$ & 0.73 & 0.00025 \\
\hline 1,2-Trans-Dichloroethylene, & & & $13500(1 \mathrm{~s})$ & 1350 \\
\hline Tribromomethane & & $320 \#$ & & \\
\hline Tributyltin & & & - & 0.026 \\
\hline 1,2,4-Trichlorobenzene & & $110 \#$ & $150(4 s)$ & $44.9(1 \mathrm{~s})$ \\
\hline 1,1,1-Trichloroethane & & $62 *$ & $5280(2 s)$ & 528 \\
\hline 1,1,2-Trichloroethane & & & $3600(3 s)$ & 940 (1s) \\
\hline Trichloroethylene & & 350 * & & \\
\hline
\end{tabular}


Table 3. (continued)

\begin{tabular}{|c|c|c|c|c|}
\hline \multirow[b]{2}{*}{ Chemical } & \multicolumn{2}{|c|}{ OSWER Values } & \multicolumn{2}{|c|}{ Region IV Values ${ }^{3}$} \\
\hline & $\begin{array}{l}\text { NAWQC } \\
\text { or FCV }\end{array}$ & Tier $\mathbf{I}^{2}$ & $\begin{array}{l}\text { Acute } \\
\text { Screening } \\
\text { Values }\end{array}$ & $\begin{array}{l}\text { Chronic Screening } \\
\text { Values }\end{array}$ \\
\hline 2,4,6-Trichlorophenol & & & $32(3 \mathrm{~s})$ & 3.2 \\
\hline m-Xylene & & m-Xylene & & \\
\hline \multicolumn{5}{|c|}{ Other } \\
\hline Chloride & & & 860,000 & 230,000 \\
\hline Chlorine (total residual - TRC) & & & 19 & 11 \\
\hline Cyanide & 5.2 & & 22 & 5.2 \\
\hline $\mathrm{pH}$ & & & & -2.5 \\
\hline Oil and Grease & & & -- & 0.01 (Low $\left.\mathrm{LC}_{s 0}\right)$ \\
\hline Sulfide ( $\left.\mathrm{S}_{2}-, \mathrm{HS}-\right)$ & & & - & 2 \\
\hline 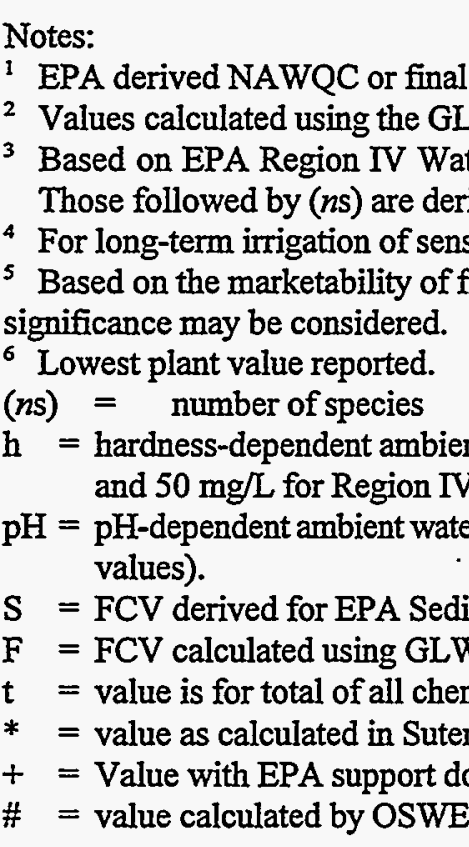 & $\begin{array}{l}\text { hronic values } \\
\text { WQI Tier II m } \\
\text { Managemer } \\
\text { ed by Region } \\
\text { tive crops (m } \\
\text { h. The use o } \\
\text { water quality } \\
\text { values). } \\
\text { quality criteri } \\
\text { ent Quality C } \\
\text { QI Tier } 1 \text { met } \\
\text { ical forms. } \\
\text { and Mabrey ( } \\
\text { uments. }\end{array}$ & $\begin{array}{l}\text { FCVs). } \\
\text { hodology. } \\
\text { Division, } \\
\text { V using sa } \\
\text { imum stand } \\
\text { ther value: } \\
\text { riterion (10 } \\
\text { (7.8 pH us } \\
\text { iteria docur } \\
\text { dology. }\end{array}$ & $\begin{array}{l}\text { Quality Sta } \\
\text { actors. } \\
\text { ch may have } \\
\mathrm{g} / \mathrm{L} \text { as } \mathrm{CaCO} \\
\text { r OSWER thr }\end{array}$ & $\begin{array}{l}\text { Unit's Screening List. } \\
\text { for ecological } \\
\text { for OSWER thresholds } \\
\text { ds and } 6.0 \text { for Region IV }\end{array}$ \\
\hline
\end{tabular}

\section{CHEMICAL-SPECIFIC INFORMATION}

This section describes the sources of information and procedures that are specific to individual elements. Except where noted, the sources of data for estimating chronic values and test EC20s for fish are the same. All data used to calculate Tier II values and estimated chronic values and EC20s are presented in Appendix A. 


\subsection{INORGANICS}

Aluminum. There are NAWQC for aluminum. The toxicity of aluminum has been shown to vary widely with water hardness and $\mathrm{pH}$ (Ingersoll et al., 1990a 1990b; Woodward et al., 1989; Sadler and Lynam, 1988; and Cleveland et al. 1986; and others). The benchmarks were calculated using only tests in circumneutral water. Lowest chronic and test EC20 values for fish are from 28-day embryolarval tests with Pimephales promelas. Kimball (n.d.) presented a CV of $5800 \mu \mathrm{g} / \mathrm{L}$, however, after further analysis of Kimball's data, the EPA (1988a) offered another value of $3288 \mu \mathrm{g} / \mathrm{L}$ as the CV for aluminum. Lowest chronic and test EC20 values for daphnids are from McCauley et al. (1986). The EPA (1988a) gives a 4-day test EC50 for Selenastrum capricornutum which is used as the plant chronic value.

Ammonia. The test EC20 value for fish is from an embryo-larval test with fathead minnows (Thurston et al. 1986). The chronic value for fish is from an early life stage test with pink salmon, Oncorhynchus gorbuscha (Rice and Bailey 1980). The chronic value for daphnids is from EPA (1985a). Chronic values were determined using Daphnia magna in life-cycle tests. EPA (1985a) provided the chronic value for aquatic plants, in which Chlorella vulgaris experienced growth inhibition (EC50). The NAWQC for ammonia are functions of temperature (T) and $\mathrm{pH}$. The acute NAWQC for ammonia is $0.52 / \mathrm{FT} / \mathrm{FPH} / 2$, and the chronic NAWQC for ammonia is 0.80/FT/FPH/Ratio, where:

$$
\begin{aligned}
& \begin{array}{lll}
\mathrm{FT}= & 10^{0.03(20 \mathrm{TCAP})} ; & \mathrm{TCAP} \leq \mathrm{T} \leq 30 \\
10^{0.03(20 \mathrm{~T})} ; & 0 \leq \mathrm{T} \leq \mathrm{TCAP}
\end{array} \\
& \text { FPH } \begin{array}{cr}
=1 ; & 8 \leq \mathrm{pH} \leq 9 \\
& 6.5 \leq \mathrm{pH} \leq 8
\end{array} \\
& 1.25 \\
& \begin{aligned}
\text { Ratio } & =16 ; & & 7.7 \leq \mathrm{pH} \leq 9 \\
& =(24) \frac{10^{7.7-\mathrm{pH}} ;}{1+10^{7.4 \mathrm{pH}}} & & 6.5 \leq \mathrm{pH} \leq 7.7
\end{aligned}
\end{aligned}
$$

TCAP $=20^{\circ} \mathrm{C}$ for acute criteria and $15^{\circ} \mathrm{C}$ for chronic criteria when Salmonids or other sensitive cold water species are present

$=25^{\circ} \mathrm{C}$ for acute criteria and $20^{\circ} \mathrm{C}$ for chronic criteria when Salmonids and other sensitive coldwater species are absent

These criteria are presented in greater detail in EPA (1985a and 1986b).

Antimony. Chronic and test EC20 values for antimony are from Kimball (n.d.). The chronic tests of Pimephales promelas were embryo-larval, and 28-day life-cycle tests were used for Daphnia magna. The EPA (1978) gives a 4-day EC50 for chlorophyll A inhibition in Selenastrum capricornutum which is used as the plant value. The SAV and SCV listed in this report are draft FAV and FCV values (EPA 1988b).

Arsenic III. NAWQC are listed for arsenic III. The lowest chronic values for fish and daphnids are given by Call et al. (1983) and Lima et al. (1984). Early life stage tests were used on Pimephales promelas and life-cycle tests were used on Daphnia magna. Cowell (1965) provides the lowest chronic value for the algae Spirogyra, Cladophora, and Zygnema which is a concentration that 
produced a $100 \%$ kill in 2 weeks. The test EC20 value is derived from Lima et al. (1984) for fish and from Call et al. (1983) and Lima et al. (1984) for daphnids.

Arsenic V. The chronic and test EC20 values for fish are from an early life stage test with Pimephales promelas (DeFoe 1982), and the test EC20 for daphnids is from Spehar et al. (1980). The estimated chronic value for daphnids was calculated with a Daphnia magna LC50 from EPA (1985b) using Equation (3). Vocke (1980) provides the plant value from a 14-day EC50 test with Scenedesmus obliquus. The SAV and SCV listed in this report are lower than the acute and chronic LOEL values listed in the Water Quality Criteria Summary (EPA 1986b).

Barium. The chronic value for daphnids is from a 21-day test on Daphnia magna by Biesinger and Christensen (1972) which resulted in $16 \%$ reproductive impairment.

Beryllium. The chronic and test EC20 values for Daphnia magna are from a life-cycle test in Kimball (n.d.). Karlander and Krauss (1972) provide the plant value for Chlorella vannieli, a 10 to $20 \%$ reduction in autotrophic growth rates. The estimated chronic and test EC20 values for fish were derived using data for Pimephales promelas from EPA (1980f) in Equations (1) and (5). The derived SAV and SCV listed in this report are lower than the lowest CV listed in the Water Quality Criteria Summary (EPA 1986b) and the acute and chronic LOEL values listed in the Water Quality Criteria Summary (EPA 1986b).

Boron. The EC20 value for daphnids was based on a 21-day test on Daphnia magna by Gerisch (1984). A 21-day test of Daphnia magna by Lewis and Valentine (1981) provided the lowest daphnid chronic value.

Cadmium. The NAWQC for cadmium are functions of water hardness. The equations for these

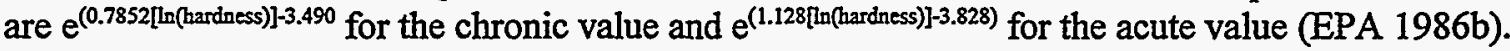
The lowest chronic value for fish is from Sauter et al. (1976) and Chapman et al. (n.d.) for daphnids. Early life stage tests were performed on brook trout, and life-cycle tests were performed on Daphnia magna. The test EC20 value is from Carlson et al. (1982) for fish and Elnabarawy et al. (1986) for daphnids. The value for aquatic plants is from Conway (1977). A relatively low cadmium concentration reduced the population growth rate of Asterionella formosa by an order of magnitude.

Calcium. The chronic value for daphnids is a concentration causing a $16 \%$ reduction in reproduction of Daphnia magna exposed to $\mathrm{CaCl}_{2} \cdot 2 \mathrm{H}_{2} \mathrm{O}$ (Biesinger and Christensen 1972). Because the highly conservative secondary values were below commonly occurring ambient concentrations of this macronutrient, they were judged to be inappropriate and are not presented.

Chromium III. The NAWQC for chromium III are functions of water hardness. The equations are $\mathrm{e}^{(0.8190[\mathrm{n}(\mathrm{hardnes})]+1.5161)}$ for the chronic value and $\mathrm{e}^{(0.8190[\mathrm{ln}(\mathrm{hardhes}))+3.638)}$ for the acute value. The lowest chronic value for fish is from an early life stage test by Stevens and Chapman (1984) on rainbow trout. Chapman et al. (n.d.) provide a chronic value from a life-cycle test of Daphnia magna. The plant value for chromium III is from a 4-day chronic test in which there was a $50 \%$ inhibition of growth of Selenastrum capricornutum (EPA 1985c). Stevens and Chapman (1984) also provided data for the test $\mathrm{EC} 20$ value for fish.

Chromium VI. There are NAWQC for chromium VI. The chronic and test EC20 values for fish are from Sauter et al. (1976). An early life stage test produced the chronic value for rainbow trout. For daphnids, a life-cycle chronic test was run by Mount (1982) on Daphnia magna, and the test 
EC20 is from Elnabarawy et al. (1986). Microcystis aeruginosa, used for the aquatic plant value, showed incipient inhibition in tests reported by the EPA (1985c).

Cobalt. The chronic and test EC20 values for cobalt are from Kimball (n.d.). Daphnia magna were used in 28-day life-cycle tests, and Pimephales promelas were used in embryo-larval tests.

Copper. The NAWQC for copper are functions of water hardness. The equations are $e^{(0.8545[\mathrm{ln}(\mathrm{harch} n \mathrm{ess})]-1.465)}$ for the chronic value and $\mathrm{e}^{(0.9422[\mathrm{n}(\mathrm{h} \text { (hardhess)]-1.464) }}$ for the acute value. The chronic and test EC20 values for fish are from an early life stage test with brook trout by Sauter et al. (1976). The daphnid chronic value is from Chapman (n.d.). The test EC20 value for daphnids is derived from Dave (1984a). A 21-day test LC50 on Daphnia magna provided the chronic value for daphnids. Arthur and Leonard (1970) provided a chronic value through 6-week tests on the amphipod, Gammarus pseudolimnaeus. Steeman-Nielsen and Wium-Anderson (1970) provide a plant value based on a lag in growth of the alga, Chlorella pyrenoidosa.

Cyanide. There are NAWQC for cyanide. The chronic and test EC20 values for fish were both from a brook trout life-cycle test by Koenst et al. (1977). Oseid and Smith (1979) provide full lifecycle test on Gammarus pseudolimnaeus, an amphipod. The alga, Scenedesmus quadricauda, showed incipient inhibition in chronic tests by the EPA (1985e).

Iron. The NAWQC for iron is based on a field study at a site receiving acid mine drainage and is not consistent with the current method for deriving criteria. The lowest chronic value for daphnids $(158 \mu \mathrm{g} / \mathrm{L})$ is a threshold for reproductive effects from a 21-day test of $\mathrm{FeCl}_{2}$ with Daphnia magna (Dave 1984c). It is considerably lower than the $4380 \mu \mathrm{g} / \mathrm{L}$ concentration causing $16 \%$ reproductive decrement in another test of $\mathrm{FeCl}_{2}$ with D. magna (Biesinger and Christensen 1972). Dave (1984c) argued that his result was more applicable to a situation in which "an acidic iron-containing waste water is discharged into a lake or a river" where it is neutralized, but Biesinger and Christensen's (1972) result "is probably more close to the steady-state situation in natural freshwater without any point source of iron." The lowest chronic value for fish is a concentration that caused $100 \%$ larval mortality in an embryo-larval test with rainbow trout exposed to dissolved iron salts (Amelung 1981).

Lead. The NAWQC for lead are functions of water hardness. The equations are $e^{(1.273[\text { [n(hardness] }]-4.705)}$ for the chronic value and $e^{(1.273[\ln (\text { hardness })]-1.460)}$ for the acute value. The lowest chronic value for fish was provided by an early life stage test on rainbow trout by Davies et al. (1976). Daphnia magna were used in 21-day tests to determine lowest chronic toxicity by Chapman et al. (manuscript). Borgmann et al. (1978) provided a chronic value for a life-cycle test on Lymnaea palastris, a snail. Chlorella vulgaris, Scenedesmus quadricauda, and Selenastrum capricornutum experienced $53 \%, 35 \%$, and $52 \%$ growth inhibition, respectively, at the plant chronic value (EPA 1985f). The test EC20 value for fish is from Sauter et al. (1976). The acute-EC20 ratio from which the SS test EC20 was calculated had to be obtained using a species mean acute value for Salmo gairdneri (EPA 1985f) since no acute value was reported by Sauter et al. (1976).

Magnesium. The chronic value for daphnids is a concentration causing a $16 \%$ reduction in reproduction of Daphnia magna exposed to $\mathrm{MgCl}_{2} \cdot 6 \mathrm{H}_{2} \mathrm{O}$ (Biesinger and Christensen 1972). Because the highly conservative secondary values were below commonly occurring ambient concentrations of this nutrient element, they were judged to be inappropriate and are not presented.

Manganese. All chronic and test EC20 values for manganese are from Kimball (n.d.). The fish chronic value is from a 28-day early life-stage test with Pimephales promelas. 
Mercury, inorganic, or total. Mercury has NAWQC. However, the chronic criterion for mercury is based on the final residue value derived from a methyl mercury bioconcentration factor. To protect aquatic life, the secondary values were derived from the EPA's (1985f) final acute and chronic values. The chronic and test EC20 values for fish are from Call et al. (1983), and those for daphnids are from Biesinger et al. (1982). The chronic tests for fish were run on Pimephales promeles throughout their embryo-larval stage. Daphnia magna were used in flow through life-cycle tests. The plant value is for incipient inhibition of Microcystis aeruginosa in an 8-day test (EPA 1985f). The acute-EC20 ratio used to calculate the SS test $\mathrm{EC}_{20}$ value had to be derived using a species mean acute value (EPA 1985g) since no acute value was reported in Biesinger et al. (1982).

Mercury, methyl. The chronic and test EC20 values for fish are from McKim et al. (1976). Brook trout were used in three generation life-cycle tests. The test EC20 value for daphnids is from Biesinger et al. (1982). The alga, Chlorella vulgaris, was used in 15-day EC50 (growth) tests by Rai et al. (1981) to determine chronic toxicity values for aquatic plants.

Molybdenum. The chronic and test EC20 values for daphnids are from Kimball (n.d.). Daphnia magna were used in a 28-day life-cycle test to determine the chronic value.

Nickel. The NAWQC for nickel are functions of water hardness. The equation for these are $\mathrm{e}^{(0.8460[\mathrm{~h}(\mathrm{hardness})]+1.1645)}$ for the chronic value and $\mathrm{e}^{(0.8460[\mathrm{In}(\mathrm{hardness})]+3.3612)}$ for the acute value. However, nickel concentrations of $10 \mu \mathrm{g} / \mathrm{L}$ in Oak Ridge Reservation stream water (considerably below the chronic NAWQC for nickel but similar to the lowest of the alternate benchmarks) reduced 7-day Ceriodaphnia dubia survivorship to $60 \%$ (Kszos et al. 1992). The chronic and test EC20 values for fish are from Nebeker et al. (1985). The chronic value for fish was determined through an early life stage test on rainbow trout. For daphnids, the chronic value was from Lazareva (1985) and the test EC20 was from Münzinger (1990). Daphnia magna were used in a life-cycle test to determine the chronic value. The caddisfly, Clistoronia magnifica, was used in life-cycle tests by Nebeker et al. (1984) to determine the chronic value. The plant chronic toxicity values were provided by the EPA (1986a) for Microcystis aeruginosa, which showed incipient inhibition.

Potassium. The chronic value for daphnids is a concentration causing a $16 \%$ reduction in reproduction of Daphnia magna exposed to $\mathrm{KCl}$ (Biesinger and. Christensen 1972). Because the highly conservative secondary values were below commonly occurring ambient concentrations of this macronutrient, they were judged to be inappropriate and are not presented.

Selenium. NAWQC are listed for selenium. The chronic and test EC20 values for fish are from Goettl and Davies (1976). Their tests were during the early life stage of rainbow trout. The chronic value for daphnids is from Kimball (n.d.), and the test EC20 is from Johnston (1987). These tests were run for 28 days on Daphnia magna. The green alga, Scenedesmus obliquus, exhibited reduced growth in the 14-day chronic toxicity tests (Vocke et al. 1980). The acute-EC20 ratio used in calculation of the SS EC20 value had to be derived using a species mean acute value for Daphnia magna (EPA 1987a) because no acute value was reported by Johniston.

Silver. The acute NAWQC for silver, which is a function of water hardness, is given by the equation $\mathrm{e}^{(1.72[\mathrm{n}(\mathrm{hardn} e \mathrm{~s})]-6.52)}$. The SCV was estimated from the FAV and acute-chronic ratios for three species. Although questions about two of these ratios prompted the EPA to refrain from calculating a final chronic value, we judged them to be better than the default value. The lowest chronic value for fish is based on an early life stage test on rainbow trout by Davies et al. (1978). The lowest chronic value for daphnids and the test EC20 for fish are from Nebeker et al. (1983). The daphnid 
CV is from a test with Daphnia magna. The test EC20 for daphnids is from Elnabarawy et al. (1986). The plant value is for growth inhibition in Chlorella vulgaris (EPA 1980y).

Sodium. The chronic value for daphnids is a concentration causing a $16 \%$ reduction in reproduction of Daphnia magna exposed to $\mathrm{NaCl}$ (Biesinger and Christensen 1972). Because the highly conservative secondary values were below commonly occurring ambient concentrations of this macronutrient, they were judged to be inappropriate and are not presented.

Strontium. The chronic value for daphnids is from 21-day tests on Daphnia magna by Biesinger and Christensen (1972) which resulted in 16\% reproductive impairment.

Thallium. Chronic and test EC20 values are from Kimball (n.d.). Embryo-larval tests were run on Pimephales promelas, and 28-day chronic tests were run on Daphnia magna. The aquatic plant value is a 4-day EC50 which reduced the cell numbers of the alga, Selenastrum capricornutum (EPA 1978).

Tin. The chronic value is from Biesinger and Christensen (1972). It caused $16 \%$ reproductive impairment in Daphnia magna in 21 days.

Uranium. The chronic value for fish is an estimate based on a fathead minnow LC50 from Cushman et al. (1977) used in Equation (1). The test EC20 is an estimate based on the same data; however, Equation (5) was used.

Vanadium. The lowest chronic and test EC20 values for fish are from Holdway and Sprague (1979) and for daphnids from Kimball (n.d.).

Zinc. The NAWQC for zinc are functions of water hardness. The equations are $\mathrm{e}^{(0.8473[\ln (\text { hardness })]+0.7614)}$ for the chronic value and $\mathrm{e}^{(0.8473[\ln (\text { hardness })+0.8604)}$ for the acute value. The chronic and test EC20 values for fish are from Spehar (1976), and the chronic value for daphnids is from Chapman et al. (n.d.). Life-cycle tests were run on Jordanella floridae and Daphnia magna. Nebeker et al. (1984) provided chronic values from life-cycle tests on the caddisfly, Clistoronia magnifica. Bartlett et al. (1974) ran 7-day tests on Selenastrum capricornutum. These aquatic plants showed incipient inhibition of growth.

Zirconium. The chronic and test EC20 values for fish are estimates based on an LC50 for Pimephales promelas from Cushman et al. (1977). These values were calculated using Equations (1) and (5).

\subsection{ORGANICS}

Acenaphthene. Although the full data requirements are not met for acenaphthene, the EPA has presented final acute and chronic values for derivation of sediment quality criteria which are presented in the criteria columns (EPA 1993b). The fish chronic value is from an early life-stage test with Pimephales promelas, and the non-daphnid chronic value is from a life-cycle test with a midge Paratanytarsus sp. (EPA 1993b). The plant value is from EPA (1978). Selenastrum capricornutum were used in 96-hour EC50 (50\% reduction in cell numbers).

Acetone. The test EC20 value for fish is an estimate based on an LC50 for rainbow trout. The chronic value for Daphnia magna is a 28-day life-cycle test from LeBlanc and Surprenant (1983). 
Anthracene. The chronic value for daphnids (Daphnia magna) was estimated using an EC50 from Holst and Giesy (1989). The chronic and test EC20 values for fish are an estimate based on an LC50 for bluegill from Oris and Giesy (1985). Calculations were performed using Equations (2), (4), and (5).

Benzene. The lowest chronic value for daphnids is given by EPA (1978). Daphnia magna were used in life-cycle tests. The lowest chronic value for aquatic plants is given by Kauss and Hutchinson (1975), which was a 48-hour test EC50 on Chlorella vulgaris. The chronic value for fish is an estimate based on data for the rainbow trout from EPA (1980d) and Equation (2). The test EC20 value for fish is derived from Black and Birge (1982). The reader should note that Black and Birge conducted a series of screening tests for a large number of chemicals on several freshwater organisms. Larval fish survival was recorded to only 4 days post-hatch, and LOECs and NOECs were not determined. These tests, then, did not generate standard chronic values and are not equivalent to the other chronic tests cited in this report. The test $\mathrm{EC} 20$ values based on tests by Black and Birge may be high relative to those from conventional chronic tests.

Benzidene. The chronic and EC20 value for fish are an estimate based on data for red shiner from EPA (1980c). Calculations were performed using Equations (2) and (5).

Benzo(a)anthracene. The chronic value for daphnids is an estimate based on data for Daphnia magna from Trucco et al. (1983) used in Equation (4).

Benzo(a)pyrene. The test EC20 for fish is derived from Hannah et al. (1982). The chronic value for daphnids is an estimate based on data for Daphnia magna from Trucco et al. (1985) used in Equation (4).

Benzoic Acid. The chronic value for fish is an estimate based on data for the mosquitofish from AQUIRE used in Equation (2). The estimated test EC20 for fish is based on the same data, but Equation (5) was used.

Benzyl Alcohol. The chronic and test EC20 values for fish are estimates based on data for bluegill from Dawson et al. (1977). The calculations were performed using Equations (2) and (5).

BHC (lindane). There are NAWQC for lindane. The chronic values for daphnids, fish, and nondaphnid invertebrates are all from Macek et al. (1976a). The test EC20 values for daphnids and fish are also from Macek et al. (1976a). The chronic values were derived from life-cycle tests run on Pimephales promelas, Daphnia magna, and the midge Chironimus tentans. The chronic value for aquatic plants is from Krishnakumari (1977); Scenedesmus acutus exhibited $20 \%$ growth inhibition in 5 days. The acute-EC20 ratio from which the SS EC20 was calculated was derived using a species mean acute value for Salvelinus fontinalis (EPA 1980s) since no acute data were reported by Macek et al. (1976a).

BHC (other). The chronic value for daphnids was estimated using a Daphnia magna EC50 from AQUIRE in Equation (4).

Bis(2-ethylhexyl)phthalate. The chronic and test EC20 values for fish are from a rainbow trout early life-stage test (Mehrle and Mayer 1976). A much lower value was reported in the previous edition of this report, but the results of that study are now believed to be incorrect (Knowles et al. 1987). The new value is supported by a CV of $912 \mu \mathrm{g} / \mathrm{L}$ from Adams and Heidolph (1985). That study is used in the derivation of the SCV because, unlike the Knowles et al. (1987) study, it has 
an accompanying acute value (48-hr EC50). No test EC20 for daphnids was calculated because insufficient detail was presented by Adams and Heidolph (1985) and Knowles et al. (1987).

2-Butanone. The chronic values for fish and daphnids are estimates based on data from Veith et al. (1983) and Randall and Knopp (1980), respectively. Equation (4) was applied to the data for Daphnia magna, and Equation (2) was applied to the data for Pimephales promelas. The test EC20 value for fish is also an estimate using Equation (5) and an LC50 from Veith et al. (1983).

Carbon disulfide. The chronic and test EC20 values for fish are estimates based on data for mosquitofish from AQUIRE using equations (2) and (5). The chronic value for daphnids is an estimate for Daphnia magna using data from Van Leeuwen (1985) in Equation (4).

Carbon tetrachloride. The chronic value for fish is a rainbow trout embryo-larval LC50 (Black and Birge 1982); therefore, it may be too high. However, it is lower than values presented by Kimball et al. (n.d.) and EPA (1980h) for fathead minnows. The same test was used to derive the test EC20 for fish (see the comments on benzene). The chronic value for daphnids is from a 7-day reproduction test with Daphnia magna (Kimball et al. n.d.). None of the subchronic tests could be used in the calculation of the SCV.

Chlordane. The chronic NAWQC for chlordane is based on the final residue value. For a criterion to protect aquatic life rather than its use, the FCV is reported. The lowest chronic and test EC20 values are derived from Daphnia magna, bluegill, and Chironomus tentans life-cycle tests (Cardwell et al. 1977).

Chlorobenzene. The chronic values for fish and daphnids are estimates based on data for bluegill and Daphnia magna from EPA (1980j). The values were calculated using Equations (2) and (4). The plant value is a 96-hour EC50 for cell number with Selenastrum capricornutum (EPA $1980 \mathrm{j})$.

Chloroform. The test EC20 value for fish is from Black and Birge (1982). (Refer to the section on benzene). The chronic value is a 27-day LC50 for rainbow trout (embryo-larval) from EPA (1980l). The EPA (1986b) gives this value as a lowest observed effect value in lieu of a NAWQC. The chronic value for daphnids is an estimate based on data for Daphnia magna from EPA (19801) and calculated from Equation (4).

DDD. The chronic and EC20 values for fish are estimates based on data for largemouth bass from Mayer and Ellersieck (1986) and are calculated using Equations (2) and (5).

DDT. The acute NAWQC for DDT is used. The chronic NAWQC, however, is not used because it is based on the final residue value. To protect aquatic life, an SCV is presented. The test EC20 value for fish is derived from Jarvinen et al. (1977). The fish chronic value is from a Pimephales promelas life-cycle test (EPA $1980 \mathrm{~m})$. The chronic value for daphnids is an estimate based on data for Daphnia pulex from EPA $(1980 \mathrm{~m})$ and calculated with Equation (4). The aquatic plant chronic value is from Sodergreen (1968). Chlorella vulgaris was affected in growth and morphology.

Decane. The chronic value for daphnids is an estimate based on data for Daphnia magna from LeBlanc (1980) used in Equation (4).

Di-n-butyl phthalate. All chronic and test EC20 values are from McCarthy and Whitmore (1985). The chronic value for daphnids is based on the geometric means of the observed 
concentration of fresh solutions and aged solutions. Daphnia magna were used in life-cycle tests, and Pimephales promelas were used in early life stage tests.

Dibenzofuran. The chronic value for daphnids is an estimate based on data for Daphnia magna from LeBlanc (1980) and used in Equation (4).

1,1-Dichloroethane. The chronic and test EC20 values for fish are estimates based on an LC50 for guppy from Koneman (1981) and calculated using Equations (2) and (5).

1,2-Dichloroethane. The chronic value for fish is from Ahmad et al. (1984). Early life stage tests were conducted on Pimephales promelas. The test EC20 value for fish is from Benoit et al. (1982). The chronic and test EC20 values for daphnids are from Daphnia magna 28-day lifecycle tests (Richter et al. 1983).

1,1-Dichloroethene. The chronic values for fish and aquatic plants are from EPA (1978). Pimephales promelas were used in embryo-larval tests. The alga. Selenastrum capricornutum, was used in a 96-hour EC50 where it exhibited loss of chlorophyll A and cell numbers. The chronic value for daphnids is an estimate based on data for Daphnia magna from EPA (1980n) used in Equation (4).

1,2-Dichloroethene. The chronic and test EC20 values for fish are estimates based on data for bluegill from EPA (1980n). These values were derived using Equations (2) and (5).

1,3-Dichloropropene. The test EC20 for fish was estimated using an LC50 for bluegill from EPA (1980o) in Equation (5). The chronic values for fish and aquatic plants are from EPA (1978). Pimephales promelas were used in an embryo-larval test, and Selenastrum capricornutum were used in a 96-hour EC50. The alga showed chlorophyll A and cell loss. The chronic value for daphnids was estimated using an EC50 for Daphnia magna from EPA (1980o) in Equation (4).

Diethyl phthalate. The plant value is a 96-hour EC50 for Selenastrum capricornutum (EPA 1978).

Di-n-octyl phthalate. All chronic and test EC20 values are from McCarthy and Whitmore (1985). Chronic values were based on Pimephales promelas in early life stage tests and Daphnia magna in life-cycle tests. There are no Tier II values for di-n-octyl phthalate because LC50s were not available.

Ethyl benzene. The chronic value for aquatic plants is from EPA (1978). Selenastrum capricornutum displayed chlorophyll A inhibition in 96-hour EC50. The chronic value for daphnids was estimated using an EC50 for Daphnia magna from EPA (1980p) in Equation (4).

Fluoranthene. Although the full data requirements are not met for fluoranthene, the EPA (1993c) has derived an FAV and FCV as a part of the derivation of sediment quality criteria which are presented in Table 1 . The fish CV is from an early life-stage test with Pimephales promelas, and the daphnid CV is from a life-cycle test with Daphnia magna EPA (1993c).

Heptachlor. The acute NAWQC for heptachlor is used. Because the chronic NAWQC is based on the final residue value, an SCV is reported herein. The chronic and test EC20 values for fish are from Macek et al. (1976b). Pimephales promelas were used in life-cycle tests to determine the chronic value for fish. The SS test EC20 value was calculated using an acute-EC20 ratio that was 
derived from a species mean acute value for Pimephales promelas (EPA 1980r) because no acute data are available from Macek et al. (1976b). The chronic value for aquatic plants is from EPA (1980r). Growth inhibition was exhibited by Selenastrum capricornutum in 96-hour EC50. The chronic value for daphnids is an estimate based on data for Daphnia pulex from EPA (1980r) using Equation (4).

Hexane. The chronic value and test EC20 value for fish are estimates based on LC50s for golden orfe from AQUIRE and calculated using Equations (2) and (5).

2-Hexanone. The chronic value and test EC20 value are estimates based on an LC50 for Pimephales promelas from Geiger et al. (1986) and calculated using Equations (2) and (5).

1-Methylnaphthalene. The chronic and test EC20 values for fish are estimates based on data for Pimephales promelas from Mattson (1976). The values were calculated with Equations (2) and (5).

4-Methyl-2-pentanone. The chronic value for fish is from Call et al. (1985). Pimephales promelas embryos, larva, and juveniles were exposed for 31 to 33 days.

2-Methylphenol. The chronic value for daphnids is an estimate based on data for Daphnia magna from Adema (1978) and Canton and Adema (1978). The value was calculated using Equation (4). The chronic and test EC20 values for fish were estimated using an LC50 for rainbow trout from DeGraeve et al. (1980) in Equations (2) and (5).

Methylene chloride. The chronic value for fish is from Dill et al. (1987). Pimephales promelas were used in 32-day embryo-larval tests. The chronic value for daphnids is an estimate based on data for Daphnia magna from LeBlanc (1980) used in Equation (4). The test EC20 value for fish is from Black and Birge (1982). (Refer to the section on benzene concerning data from this source.)

Naphthalene. The chronic and test EC20 values for fish are from DeGraeve et al. (1982), and the test EC20 value for daphnids is from Geiger and Buikema (1982). Pimphales promelas were used in embryo-larval tests to determine chronic toxicity. The chronic value for aquatic plants is from EPA (1980t). The alga, Chlorella vulgaris, exhibited inhibited cell numbers in 48-hour EC50. The chronic value for daphnids is an estimate based on data for Daphnia magna from EPA (1980t) used in Equation (4).

4-Nitrophenol. The chronic and test EC20 values for daphnids are from Francis et al. (1986). The chronic and test EC20 values for fish are estimates based on data for bluegill from Buccafusco et al. (1981) and used with Equations (2) and (5). The EPA (1978) is the source for the chronic value for aquatic plants. Selenastrum capricornutum exhibited chlorophyll A reduction in 96-hour EC50.

$\mathrm{N}$-nitrosodiphenylamine. The source for the estimated fish and daphnid chronic values are Buccafusco et al. (1981) and LeBlanc (1980), respectively. Equation (2) was used to calculate the estimated fish (bluegill) value, and Equation (4) was used for the estimated daphnid (Daphnia magna) value. The test EC20 value for fish is also an estimate. Buccafusco et al. (1981) provided the LC50 for bluegill used with Equation (5) to estimate the EC20.

PCBs: Total. There are NAWQC for PCBs, but the chronic criterion is based on the final residue value. Since that value is intended to protect the use of aquatic life, an SCV is calculated to protect the aquatic life itself. The fish lowest chronic value and test EC20 are from a full life-cycle test of fathead minnows by DeFoe (1978). The lowest chronic value and test EC20 for daphnids are 
from a 2-week continuous flow test with Daphnia magna (Nebeker and Puglisi 1974). The lowest chronic value for non-daphnid invertebrates is from a 3-week LC50 for Tanytarsis dissimilis by Nedeker and Puglisi (1974). The lowest plant value is for reduction in carbon fixation by Scenedesmus quadricaudata in a 24-hour test (Laird 1973).

PCBs: Aroclor ${ }^{\otimes}$ 1221. The chronic and test EC20 fish values are estimates based on data for cutthroat trout by Stalling and Mayer (1972). Equations (2) and (5) were used to determine the EC20 value for fish. The chronic value for aquatic plants is a 48-hour LC50 for Euglena gracilis (Ewald et al. 1976).

PCBs: Aroclor ${ }^{\circledR}$ 1232. The chronic and test EC20 fish values are estimates based on data for cutthroat trout by Stalling and Mayer (1972) and AQUIRE. The geometric mean was derived from these two values and then placed into Equations (2) and (5).

PCBs: Aroclor ${ }^{\circledast}$ 1242. The chronic and test EC20 values for fish are from Nebeker et al. (1974). Pimephales promelas were used in full life-cycle tests. The chronic values for non-daphnid invertebrates are from Nebeker and Puglisi (1974). Gammarus pseudolimnaeus were exposed to PCBs for 2 months in a continuous-flow system. The chronic value for aquatic plants is a 24-hour test in which Scenedesmus obtusiusculus showed growth inhibition (Larsson and Tillberg 1975).

PCBs: Aroclor $^{\circledR}$ 1248. The chronic and test EC20 values for fish are from DeFoe et al. (1978), and the chronic and test EC20 values for daphnids are from Nebeker and Puglisi (1974). The chronic values for fish were full life-cycle tests carried out on Pimephales promelas. The chronic value for daphnids was determined through 3-week exposures that created a $16 \%$ reproductive impairment in Daphnia magna. The chronic value for a non-daphnid invertebrate is from Nebeker and Puglisi (1974). Gammarus pseudolimnaeus was exposed for 2 months.

PCBs: Aroclor ${ }^{\circledR}$ 1254. The chronic value for fish is from a brook trout life-cycle test (Mauck et al. 1978), and the test EC20 value is from a fathead minnow life-cycle test (Nebeker et al. 1974). The chronic and test EC20 values for daphnids are from Nebeker and Puglisi (1974). Daphnia magna were exposed for 2 weeks in a continuous-flow environment. The lowest chronic value for nondaphnid invertebrates is from a 3-week LC50 for Tanytarsis dissimilis by Nedeker and Puglisi (1974). The lowest plant value is for reduction in carbon fixation by Scenedesmus quadricaudata in a 24-hour test (Laird 1973).

PCBs: Aroclor ${ }^{\otimes}$ 1260. The chronic and test EC20 values for fish are from DeFoe et al. (1978). The chronic value is ambiguous because significant effects occurred at the lowest concentration tested in a 30-day fathead minnow larval test at the lowest concentrations tested $(1.3 \mu \mathrm{g} / \mathrm{L})$ but not in a 240 day lifecycle at the highest concentration tested $(2.1 \mu \mathrm{g} / \mathrm{L})$.

1-Pentanol. The chronic and test EC20 values for fish are estimates based on data for rainbow trout from AQUIRE and calculated using Equations (2) and (5).

Phenanthrene. The chronic and test EC20 values for daphnids are from Geiger and Buikema (1982). The chronic value was determined using Daphnia pulex in full life-cycle tests.

Phenol. The chronic and test EC20 values for fish are from fathead minnow embryo-larval tests (DeGraeve et al. 1980). The chronic value for daphnids is an estimate based on data for Daphnia longispina from EPA (1980v) and calculated using Equation (4). The chronic value for aquatic plants 
is from Reynolds (1975). Selenastrum capricornutum exhibited $60 \%$ reduction in cell numbers and $12 \%$ growth inhibition.

2-Propanol. The chronic and test EC20 values for fish are estimates based on data for Pimephales promelas from AQUIRE and Veith et al. (1983). The geometric mean of these LC50s was used in Equations (2) and (4).

1,1,2,2-Tetrachloroethane. The chronic and test EC20 values for fish are from Ahmad et al. (1984), and the values for daphnids are from Richter et al. (1983). The chronic values for fish were derived from embryo-larval tests on Pimephales promelas. The chronic values for daphnids were derived from 28-day tests run on Daphnia magna. The chronic value for aquatic plants is from EPA (1978). Selenastrum capricornutum exhibited chlorophyll A inhibition in 96-hour EC50.

Tetrachloroethene. The chronic value for fish is an embryo-larval test on fathead minnows (EPA 1980aa). The test EC20 value for fish is from Ahmad et al. (1984). The chronic and test EC20 values for daphnids are from Richter et al. (1983). These were 28-day tests on Daphnia magna. The plant value is from EPA (1978). Selenastrum capricornutum decreased in cell number and chlorophyll A during the 96-hour EC50.

Toluene. The chronic value is an estimate based on data for Daphnia magna from EPA (1980cc) and calculated using Equation (4). The chronic value from Pimephales promelas is from Devlin et al. (1982). The test EC20 value for fish is from Black and Birge (1982). (Refer to the section on benzene.) Chlorella vulgaris was used in 10-day tests by Kauss and Hutchinson (1975) to determine the chronic value for aquatic plants.

1,1,1-Trichloroethane. The chronic value and test EC20 value for daphnids are from Thompson and Carmichael (1989). Daphnia magna were used in 17-day chronic tests. The chronic value and test EC20 for fish were estimated based on data for Pimephales promelas from Alexander et al. (1978) and calculated using Equation (2). The chronic value for aquatic plants is from EPA (1978). Selenastrum capricornutum decreased in chlorophyll A and cell numbers in the 96-hour EC50.

1,1,2-Trichloroethane. The chronic value and test EC20 values for fish are from Ahmad et al. (1984) and the chronic and test EC20 values for daphnids are from Richter et al. (1983). The chronic value for fish is based on 32-day embryo-larval tests on Pimephales promelas, while the chronic value for daphnids is based on 28-day tests on Daphnia magna.

Trichloroethene. The chronic and test EC20 values for fish are from Smith et al. (1991). Jordanella floridae, the flagfish, was used in 28-day embryo-larval tests. The chronic value for daphnids is an estimate based on data for Daphnia pulex from EPA (1980dd) and calculated using Equation (4).

Vinyl acetate. The chronic and test EC20 values for fish are estimates based on an LC50 for Pimephales promelas from AQUIRE calculated using Equations (2) and (5).

Xylene. The chronic value for fish is an estimate based on an LC50 for common carp from AQUIRE and calculated using Equation (2). The test EC20 value for fish is from Black and Birge (1982). (Refer to the section on benzene.) 


\section{APPLICATION OF BENCEIMARKS}

Use of these aquatic screening benchmarks requires that the assessor choose which benchmarks to employ and which water concentrations to apply them to. The choice of benchmarks depends on the interpretation of the benchmarks, their regulatory standing, and their degree of conservatism.

Each of the alternative benchmarks has a different interpretation. Exceedances of NAWQC create a regulatory imperative for action under the Comprehensive Environmental Response, Compensation, and Liability Act (CERCLA) because they are ARARS. Exceedance of a Tier II value implies a greater than $20 \%$ chance that the NAWQC, if their value vrere known, would be exceeded. Exceedance of a CV indicates that the field concentration is greater than a concentration dividing statistically insignificant from significant effects in a chronic toxicity test. Exceedance of a test EC20 indicates that biologically significant effects levels were exceeded in a chronic toxicity test. Exceedance of the SS test EC20 indicates that a biologically significant effect level may be exceeded in a sensitive species. Exceedance of a population EC20 indicates that a significant reduction in a largemouth bass population could occur. Therefore, exceedance of either the acute or chronic NAWQC indicates a need for action. Exceedance of an SCV implies a low risk. Exceedance of any of the other benchmarks indicates a risk of real effects that should lead to additional data collection and assessment. However, these inferences all depend on comparison of the benchmarks to appropriate water concentrations.

Contaminant screening is not a regulatory process, but managers at some sites prefer to use only values that have regulatory standing. The NAWQC are clearly regulatory values in that they are ARARS and have been adopted by Tennessee and most other states as water quality standards. Lowest chronic values (the last column in Table 1) have been presented by the EPA in place of NAWQC (EPA 1986b), but they are not criteria. They merely indicate that the EPA believes toxic effects may occur at that concentration. The Tier II values (SAV and SCV) are proposed by the EPA as values that could be used for regulatory enforcement in the Great Lakes (EPA 1993a). They are more conceptually consistent with the NAWQC than lowest chronic values and may come to have the same standing as NAWQC, but currently they are only proposed by the EPA.

OSWER's Ecotox Thresholds and Region IV's screening values (or values proposed by other regions) are alternative benchmark sets derived by the EPA. Both are based on NAWQC values; however, Region IV uses values adjusted to $50 \mathrm{ppm}$ hardness which is unrealistically conservative for most sites, while OSWER adjusts to dissolved-phase concentrations which are not available for most screening assessments. In addition, Region IV uses NAWQCs based on fish marketability which is not relevant to protecting aquatic life. Therefore, the standard EPA Office of Water NAWQC values and FCVs in Table 1 will be more useful in most cases. When NAWQCs are not available, the ETs correspond to SCVs, but some of the SCVs have been superseded by values presented in Table 1 of this document. When NAWQCs are not available, the SVs are based on divisions of lowest toxic values by 10 or 100 which is equivalent to derivation of SAVs and SCVs but is not as scientifically defensible. Therefore, for the Oak Ridge Reservation and many other sites, the NAWQCs and Tier II values listed in Table 1 are generally preferable to either the ETs or SVs.

As discussed in the introduction, the chronic benchmarks are to be used as lower screening benchmarks. The acute NAWQC and SAVs are to be used as upper screening benchmarks. However, because of their conservatism, exceedance of the SAV cannot be taken to indicate that severe effects are likely to be occurring. If an SAV is exceeded, the assessor should examine the acute values used to generate the Tier II values (Appendix A) and judge whether in fact severe effects are likely. 
All of these benchmarks are based on toxicity tests conducted in the laboratory. Therefore, they should be compared to water concentrations that are as equivalent as possible to concentrations in test water which is nearly all dissolved. The EPA Office of Water has decided that for metals the appropriate comparison is to concentrations in 0.1 to $0.45 \mu \mathrm{m}$ filtered ambient water (HECD 1992, Prothro 1993). Acid soluble or even total recoverable concentrations, rather than dissolved concentrations, are often reported because they are required for human health risk assessments. In addition, Region IV and most other EPA regional offices require use of acid soluble concentrations in ecological risk assessments for the sake of conservatism. However, acid soluble concentrations of metals typically include 30 to $95 \%$ particle bound material (HECD 1992). Therefore, acid soluble concentrations should be used for aquatic ecological risk assessments to satisfy the regional regulators, but dissolved concentrations should also be used if possible for a realistic screening of the chemicals and to make realistic estimates of risk.

The NAWQC for hardness dependent metals are based on a hardness of $100 \mathrm{mg} / \mathrm{L}$, which is appropriately conservative for ambient waters on the Oak Ridge Reservation. If these benchmarks are applied to a site with hard or soft water, the NAWQC for those metals should be recalculated as recommended by the EPA.

\section{REFERENCES}

Adams, W. J. and B. B. Heidolph. 1985. Short-cut chronic toxicity estimates using Daphnia magna. pp. 87-102. in R. D. Cardwell, R. Purdy, and R. C. Bahner (eds.), Aquatic Toxicity and Hazard Assessment, Seventh Symposium. ASTM, Philadelphia, PA.

Adams, W. J., G. R. Biddinger, K. A. Robillard. 1995. A summary of the acute toxicity of 14 phthalate esters to representative aquatic organisms. Environ. Toxicol. Chem. 14:1569-1574.

Adelman, I. R., L. L. Smith, and G. D. Siesennop. 1976. Chronic toxicity of Guthion to the fathead minnow (Pimephales promelas Rafinesque). Bull. Environ. Contam. Toxicol. 15:726-733.

Adema, D. M. M. 1978. Daphnia magna as a test animal in acute and chronic toxicity tests. Hydrobiologia. 59:125-134.

Adema, D. M. M. and I. G. J. Vink. 1981. A comparative study of the toxicity of 1,1,2-trichloroethane, dieldrin, pentachlorophenol and 3,4 dichloroaniline for marine and fresh water organisms. Chemosphere. 10:533-554.

Adema, D. M. M., J. H. Canton, W. Slooff, and A. O. Hanstveit. 1981. Research for a useful combination of test methods to determine the aquatic toxicity of environmentally dangerous chemicals. Rep. No. CL81/100, Natl. Inst. Public Health Environ. Hyg., the Netherlands.

Ahmad, N. et al. 1984. Aquatic toxicity tests to characterize the hazard of volatile organic chemicals in water: A toxicity data summary -Parts I and II. EPA-600/3-84-009. U.S. Environmental Protection Agency, Duluth, Minn.

Alexander, H. C., W. M. McCarthy, and E. A. Bartlett. 1978. Toxicity of perchloroethylene, trichloroethylene, 1,1,1-trichloroethane, and methylene chloride to fathead minnows. Bull. Environ. Contam. Toxicol. 20:344-352. 
Allison, D. T. and R. O. Hermanutz. 1977. Toxicity of diazinon to brook trout and fathead minnows. EPA-600/3-77-060. U.S. Environmental Protection Agency, Duluth, Minn.

Amelung, M. 1981. Auswirkungen gelöster Eisenverbindungen auf die Ei- und Larvalentwicklung von Salmo gairdneri (Richardson). Arch. Fisch Wiss. 32:77-87.

Anderson, D. R. and E. B. Lusty. 1980. Acute toxicity and bioaccumulation of chloroform to four species of freshwater fish. PNL-3046. NUREG/CR-0893. Report No. CR-0893, U.S. Nuclear Reg. Comm., Washington, D. C.

Arthur, J. W. and E. N. Leonard. 1970. Effects of copper on Gammarus pseudolimnaeus, Physa integra, and Campeloma decisum in soft water. J. Fish. Res. Bd. Canada. 27:1277-1283.

Arthur, J. W. and J. G. Eaton. 1970. Effects of copper on Gammarus pseudolimnaeus and the fathead minnow (Pimephales promelas). J. Fish. Res. Boara' Canada. 28:1841-1845.

Bailey, H. C., D. H. W. Liu, and H. A. Javitz. 1985. Time/toxicity relationships in short-term static, dynamic, and plug-flow bioassays. in R. C. Bahner and D. J. Hansen (eds.), Aquatic Toxicology and Hazard Assessment, Eighth Symposium, ASTM STP 891, Philadelphia, PA.

Barnthouse, L. W., G. W. Suter II, and A. E. Rosen. 1990. Risks of toxic contaminants to exploited fish populations: influence of life history, data uncertainty and exploitation intensity. Environ. Toxicol. Chem. 9:297-311.

Bartell, S. M. 1990. Ecosystem context for estimating stress-induced reductions in fish populations, pp. 167-182, in American Fisheries Society Special Symposium 8. Bethesda, MD.

Bartlett, L. and F. W. Rabe. 1974. Effects of copper, zinc, and cadmium on Selenastrum capricornutum. Water Res. 8:179-185.

Benoit, D. A. 1975. Chronic effects of copper on survival, growth, and reproduction of the bluegill (Lepomis macrochirus). Trans. Am. Fish. Soc. 104:353-358.

Benoit, D. A., and G. W. Holcombe. 1978. Toxic effects of zinc on fathead minnows Pimephales promelas in soft water. J. Fish Biol. 13:701-708.

Benoit, D. A., F. A. Puglisi, and D. L. Olson. 1982. A fathead minnow Pimephales promelas early life stage toxicity test method evaluation and exposure to four organic chemicals. Environ. Pollut. Ser. A Ecol. Biol. 28:189-197.

Biesinger, K. E., L. E. Anderson, and J. G. Eaton. 1982. Chronic effects of inorganic and organic mercury on Daphnia magna: toxicity, accumulation, and loss. Arch. Environm. Contam. Toxicol. 11:769-774.

Biesinger, K. E. and G. M. Christensen. 1972. Effects of various metals on survival, growth, reproduction, and metabolism of Daphnia magna. J. Fish. Res. Bd. Canada. 29:1691-1700.

Birge, W. J., J. A. Black, and A. G. Westerman. 1978. Effects of polychlorinated biphenyl compounds and proposed $P C B$-replacement products on embryo-larval stages of fish and amphibians. Res. Rep. No. 118, University of Kentucky, Water Resour. Res. Inst., Lexington, KY. 
Black, J. A. and W. J. Birge. 1982. The aquatic toxicity of organic compounds to embryo-larval stages of fish and amphibians. University of Kentucky, Water Resources Research Institute, Lexington, Kentucky.

Bluzat, R, O. Junot, G. Lespinasse, and J. Seuge. 1979. Chronic toxicity of acetone in the fresh water snail Lymnea stagnalis. Toxicology. 14:179-190.

Borgmann, U., O. Kramar, and C. Loveridge. 1978. Rates of mortality, growth, and biomass production of Lymnaia palustris during chronic exposure to lead. J. Fish. Res. Board Can. 35:1109-1115.

Brooke, L. T., D. J. Call, D. L. Geiger, and C. E. Northcott. 1984. Acute toxicities of organic chemicals to fathead minnows (Pimephales promelas), Vol. 1. Center for Lake Superior Environmental Studies, University of Wisconsin, Superior, WI.

Brungs, W. A. 1969. Chronic toxicity of zinc to the fathead minnow Pimephales promelas Rafinesque. Trans. Am. Fish. Soc. 98:272-279.

Buccafusco, R. J., S. J. Ells, and G. A. LeBlanc. 1981. Acute toxicity of priority pollutants to bluegill (Lepomis macrochirus). Bull. environ. Contam. Toxicol. 26:446-452.

Buhl, K. J. and S. J. Hamilton. 1990. Comparative toxicity of inorganic contaminants released by placer mining to early life stages of Salmonids. Ecotoxicol. Enviorn. Saf. 20:325-342.

Buikema, A. L. Jr., J. Cairns, Jr., and G. W. Sullivan. 1974. Evaluation of Philodina acuticornis (Rotifera) as bioassay organisms for heavy metals. Water Resour. Bull. Am. Water Res. Assoc. $10: 648-661$.

Cairns, J. Jr and A. Scheier. 1968. A comparison of the toxicity of some common industrial waste components tested individually and combined. Prog. Fish-Cult. 30:3-8

Call, D. J., L. T. Brook, N. Ahmad, and J. E. Richter. 1983. Toxicity and metabolism studies with EPA priority pollutants and related chemicals in freshwater organisms. EPA-600/3-83-095. U.S. Environmental Protection Agency, Duluth, Minn.

Call, D. J., L. T. Brook, M.L. Knuth, S. H. Poirer, and M.D. Hoglund. 1985. Fish subchronic toxicity prediction model for industrial organic chemicals that produce narcosis. Environ. Toxic. and Chem. 4:335-341.

Call, D. J., L. T. Brooke, S. L. Harting, S. H. Poirier and D. J. McCauley. 1986. Toxicity of phenanthrene to several freshwater species. Report to Battelle Memorial Research Institute, Columbus, OH, Subcontract No. F-4114 (8834)-411, Work Assignment No. 45. Center for Lake Superior Environmental Studies, University of Wisconsin-Superior, Superior, WI.

Canton, J. H. and D. M. M. Adema. 1978. Reproducibility of short-term and reproduction toxicity experiments with Daphnia magna and comparison of the sensitivity of Daphnia magna with Daphnia pulex and Daphnia cucullata in short-term experiments. Hydrobiologia 59:135-140. 
Canton, J. H., P. A. Greve, W. Slooff, and G. J. Van Esch. 1975. Toxicity, accumulation and elimination studies of alpha-hexachlorocyclohexane (alpha-HCH) with freshwater organisms of different trophic levels. Water Res. 9:1163-1169.

Cardwell, R. D., D. G. Foreman, T. R. Payne, and D. J. Wilbur. 1976. Acute toxicity of selected toxicants to six species of fish. EPA-600/3-76-008, U.S. EPA, Duluth, MN.

Cardwell, R. D., D. G. Foreman, T. R. Payne, and D. J. Wilbur. 1977. Acute and chronic toxicity of chlordane to fish and invertebrates, EPA-600/3-77-019. U.S. Environmental Protection Agency, Duluth, Minn.

Carlson, A. R. and P. A. Kosian. 1987. Toxicity of chlorinated benzenes to fathead minnows (Pimephales promelas). Arch. Environ. Contam. Toxicol. 16:129-135.

Carlson, A. R. et al. 1982. Cadmium and endrin toxicity to fish in waters containing mineral fibers, EPA-600/3-82-053. U.S. Environmental Protection Agency, Duluth, Minn.

Chandler, J. H. Jr., and L. L. Marking. 1979. Toxicity of fishery chemicals to the Asiatic clam, Corbicula manilensis. Prog. Fish-Cult. 41:148-151.

Chapman, G. A., S. Ota, and F. Recht. n.d. Effects of water hardness on the toxicity of metals to Daphnia magna. U.S. Environmental Protection Agency, Corvallis, Oregon.

Cleveland, L., E. E. Little, S. J. Hamilton, D. R. Buckler, and J. B. Hunn. 1986. Interactive toxicity of aluminum and acidity to early life stages of brook trout. Trans. Amer. Fish. Soc. 115:610-620.

Conway, H. L. 1977. Sorption of arsenic and cadmium and their effects on growth, micronutrient utilization, and photosynthetic pigment composition of Asterionella formosa. J. Fish. Res. Board Can. 35:26-294.

Couture, P., C. Blaise, D. Cluis, and C. Bastien. 1989. Zirconium toxicity assessment using bacteria, algae and fish assays. Water Air Soil Pollut. 47:87-100.

Cowell, B. C. 1965 . The effects of sodium arsenite and silex on the plankton populations in farm ponds. Trans. Am. Fish. Soc. 94:371-377.

Cowgill, U. M., I. T. Takahashi, and S. L. Applegath. 1985. A. comparison of the effect of four benchmark chemicals on Daphnia magna and Ceriodaphnia dubia affinis tested at two different temperatures. Environ. Toxicol. Chem. 4:415-422.

Cowgill, U. M. and D. P. Milazzo. 1991. The sensitivity of Ceriodaphnia dubia and Daphnia magna to seven chemicals utilizing the three-bood test. Arch. Environ. Contam. Toxicol. 20:211-217.

Cushman, R. M., S. G. Hildebrand, R. H. Strand, and R. M. Anderson. 1977. The toxicity of 35 trace elements in coal to freshwater biota: a data base with automated retrieval capabilities. ORNL/TM-5793. Oak Ridge National Laboratory.

Dave, G. 1984a. Effects of copper on growth, reproduction, survival and haemoglobin in Daphnia magna. Comp. Biochem. Physiol. 78C:439-443. 
Dave, G. 1984b. Effects of fluoride on growth, reproduction, and survival in Daphnia magna. Comp. Biochem. Physiol. 78C:425-431.

Dave, G. 1984c. Effects of waterborne iron on growth, reproduction, survival and haemoglobin in Daphnia magna. Comp. Biochem. Physiol. 78C:433-438.

Davies, P. H., J. P. Goettl, Jr., and J. R. Sinley. 1978. Toxicity of silver to rainbow trout (Salmo gairdneri). Water Res. 12:113-117.

Davies, P. H., J. P. Goettl, Jr., J. R. Sinley, and Smith. 1976. Acute and chronic toxicity of lead to rainbow trout Salmo gairdneri, in hard and soft water. Water Res. 10:199-206.

Dawson, G. W., A. L. Jennings, D. Drozdowski, and E. Rider. 1977. The Acute toxicity of 47 Indistrial chemicals to fresh and saltwater fishes. J. Hazard. Mater. 1:303-318.

DeFoe, D. L., G. D. Veith, and R. L. Carlson. 1978. Effects of Aroclor 1248 and 1260 on the fathead minnow (Pimephales promelas). J. Fish. Res. Board Can. 7:997-1002.

DeFoe, D. L. 1982. Arsenic (V) Test Results. U.S. EPA, Duluth, MN (Memo to R. L. Spehar, U.S. EPA, Duluth, MN).

DeGraeve, G. M., D. L. Geiger, J. S. Meyer, and H. L. Bergman. 1980. Acute and embryo-larval toxicity of phenolic compounds to aquatic biota. Arch. Environ. Contam. Toxicol. 9:557-568.

DeGraeve, G. M., R. G.Elder, D. C.Woods, and H.L.Bergman. 1982. Effects of naphthalene and benzene on fathead minnows and rainbow trout. Arch. Environ. Contam. Toxicol. 11:487-490.

Devlin, E. W., J. D. Brammer, and R. L. Puyear. 1982. Acute toxicity of toluene to three age groups of fathead minnows (Pimephales promelas). Bull. Enviorn. Contam. Toxicol. 29:12-17.

Dill, D. C., W. M. McCarthy, H. C. Alexander, and E. A. Bartlett. 1980. Toxicity of 1,1Dichloroethylene (Vinylidene chloride) to aquatic organisms. Ecol. Res. Ser., EPA-600/3-80057, Environ. Res. Lab., U.S. EPA, Duluth, MN.

Dill, D. C., P. G. Murphy, and M. A. Mayes. 1987. Toxicity of methylene chloride to life stages of the fathead minnow, Pimephales promelas Rafinesque. Bull. Environ. Contam. Toxicol. 39:869-876.

Ding, S. R. 1980. Acute Toxicities of vanadium, nickel, and cobalt to several species of aquatic organisms. Environ. Qual. 1:17-21.

Dominguez, S. E. and G. A. Chapman. 1984. Effect of pentachlorophenol on the growth and mortality of embryonic and juvenile steelhead trout. Arch. Environ. Contam. Toxicol. 13:739-743.

Dwyer, W. P., F. L. Mayer, J. L. Allen, and D. R. Buckler. 1978. Chronic and simulated use-pattern exposures of brook trout (Salvelinus fontinalis) to 3-trifluoromethyl-4-nitrophenol (TFM). Investigations in Fish Control. 84:1-6.

Eaton, J. G. 1974. Chronic cadmium toxicity to the bluegill (Lepomis macrochirus Rafinesque). Trans. Am. Fish. Soc. 103:729-735. 
Elnabarawy, M. T., A. N. Welter, and R. R. Robideau. 1986. Relative sensitivity of three daphnid species to selected organic and inorganic chemicals. Environ. Toxicol. Chem. 5:393-398.

EPA. (n.d.). AQUIRE: Aquatic Information Retrieval Toxicity Data Base. National Technical Information Service, Springfield, Va.

EPA. 1978. In-depth studies on health and environmental impacts of selected water pollutants. Contract No. 68-01-4646, U. S. EPA, Duluth, MN (also known as C. E. Stephan's Table of Data).

EPA. 1980a. Ambient water quality criteria for acenaphthene. EPA 440/5-80-015. U.S. Environmental Protection Agency, Washington, D.C.

EPA. 1980b. Ambient water quality criteria for antimony. EPA 440/5-80-020. U.S. Environmental Protection Agency, Washington, D.C.

EPA. 1980c. Ambient water quality criteria for benzidene. EPA 440/5-80-023. U.S. Environmental Protection Agency, Washington, D.C.

EPA. 1980d. Ambient water quality criteria for benzene. EPA 440/5-80-018. U.S. Environmental Protection Agency, Washington, D.C.

EPA. 1980e. Ambient water quality criteria for benzidene. EPA 440/5-80-023. U.S. Environmental Protection Agency, Washington, D.C.

EPA. 1980f. Ambient water quality criteria for beryllium. EPA 440/5-80-024. U.S. Environmental Protection Agency, Washington, D.C.

EPA. 1980g. Ambient water quality criteria for cadmium. EPA 440/5-80-025. U.S. Environmental Protection Agency, Washington, D.C.

EPA. 1980h. Ambient water quality criteria for carbon tetrachloride. EPA 440/5-80-026. U.S. Environmental Protection Agency, Washington, D.C.

EPA. 1980i. Ambient water quality criteria for chlordane. EPA 440/5-80-027. U.S. Environmental Protection Agency, Washington, D.C.

EPA. 1980j. Ambient water quality criteria for chlorinated benzenes. EPA 440/5-80-028. U.S. Environmental Protection Agency, Washington, D.C.

EPA. 1980k. Ambient water quality criteria for chlorinated ethanes. EPA 440/5-80-029. U.S. Environmental Protection Agency, Washington, D.C.

EPA. 19801. Ambient water quality criteria for chloroform. EPA 440/5-80-033. U.S. Environmental Protection Agency, Washington, D.C.

EPA. 1980 m. Ambient water quality criteria for DDT. EPA 440/5-80-038. U.S. Environmental Protection Agency, Washington, D.C.

EPA. 1980n. Ambient water quality criteria for dichloroethylenes. EPA 440/5-80-041. U.S. Environmental Protection Agency, Washington, D.C. 
EPA. 1980o. Ambient water quality criteria for dichloropropane and dichloropropene. EPA 440/5-80-043. U.S. Environmental Protection Agency, Washington, D.C.

EPA. 1980p. Ambient water quality criteria for ethylbenzene. EPA 440/5-80-048. U.S. Environmental Protection Agency, Washington, D.C.

EPA. 1980q. Ambient water quality criteria for fluoranthene. EPA 440/5-80-049. U.S. Environmental Protection Agency, Washington, D.C.

EPA. 1980r. Ambient water quality criteria for heptachlor. EPA 440/5-80-052. U.S. Environmental Protection Agency, Washington, D.C.

EPA. 1980s. Ambient water quality criteria for hexachlorocyclohexane. EPA 440/5-80-054. U.S. Environmental Protection Agency, Washington, D.C.

EPA. 1980t. Ambient water quality criteria for naphthalene. EPA 440/5-80-059. U.S. Environmental Protection Agency, Washington, D.C.

EPA. 1980u. Ambient water quality criteria for nitrophenols. EPA 440/5-80-063. U.S. Environmental Protection Agency, Washington, D.C.

EPA. 1980v. Ambient water quality criteria for phenol. EPA 440/5-80-066. U.S. Environmental Protection Agency, Washington, D.C.

EPA. 1980w. Ambient water quality criteria for phthalate esters. EPA 440/5-80-067. U.S. Environmental Protection Agency, Washington, D.C.

EPA. 1980x. Ambient water quality criteria for polychlorinated biphenyls. EPA 440/5-80-068. U.S. Environmental Protection Agency, Washington, D.C.

EPA. 1980y. Ambient water quality criteria for silver. EPA 440/5-80-071. U.S. Environmental Protection Agency, Washington, D.C.

EPA. 1980z. Ambient water quality criteria for beryllium. NTIS, Springfield, Virginia.

EPA. 1980aa. Ambient water quality criteria for tetrachloroethylene. EPA 440/5-80-073. U.S. Environmental Protection Agency, Washington, D.C.

EPA. 1980bb. Ambient water quality criteria for thallium. EPA 440/5-80-074. U.S. Environmental Protection Agency, Washington, D.C.

EPA. 1980cc. Ambient water quality criteria for toluene. EPA 440/5-80-075. U.S. Environmental Protection Agency, Washington, D.C.

EPA. 1980dd. Ambient water quality criteria for trichloroethylene. EPA 440/5-80-077. U.S. Environmental Protection Agency, Washington, D.C.

EPA. 1980ee. Ambient water quality criteria for nitrosamines. EPA 440/5-80-064. U.S. Environmental Protection Agency, Washington, D.C. 
EPA. 1984a. Ambient water quality criteria for cadmizm - 1984. EPA 440/5-84-032. U.S. Environmental Protection Agency, Washington, D. C.

EPA. 1985a. Ambient water quality criteria for ammonia - 1984. EPA 440/5-85-001. U.S. Environmental Protection Agency, Washington, D.C.

EPA. 1985b. Ambient water quality criteria for arsenic - 1984. EPA 440/5-84-033. U.S. Environmental Protection Agency, Washington, D.C.

EPA. 1985c. Ambient water quality criteria for chromium - 1984. EPA 440/5-84-029. U.S. Environmental Protection Agency, Washington, D.C.

EPA. 1985d. Ambient water quality criteria for copper - 1984. EPA 440/5-84-031. U.S. Environmental Protection Agency, Washington, D.C.

EPA. 1985e. Ambient water quality criteria for cyanide - 1984. EPA 440/5-84-030. U.S. Environmental Protection Agency, Washington, D.C.

EPA. 1985f. Ambient water quality criteria for lead - 1984. EPA 440/5-84-027. U.S. Environmental Protection Agency, Washington, D.C.

EPA. 1985g. Ambient water quality criteria for mercury - 1984. EPA 440/5-84-026. U.S. Environmental Protection Agency, Washington, D.C.

EPA. 1986a. Ambient water quality criteria for nickel - 1986. EPA 440/5-86-004. U.S. Environmental Protection Agency, Washington, D.C.

EPA. 1986b. Quality criteria for water. EPA 440/5-86-001. U.S. Environmental Protection Agency, Washington, D.C.

EPA. 1987a. Ambient water quality criteria for selenium, 1987. EPA 440/5-87-006. U.S. Environmental Protection Agency, Washington, D.C.

EPA. 1987b. Ambient water quality criteria for zinc, 1987. EPA 440/5-87-003. U.S. Environmental Protection Agency, Washington, D.C.

EPA. 1988a. Ambient water quality criteria for aluminum - 1988. EPA 440/5-86-008. U.S. Environmental Protection Agency, Washington, D.C.

EPA. 1988b. Ambient water quality criteria for antimony(III). Draft. August 30th, 1988. U.S. Environmental Protection Agency, Washington, D.C.

EPA. 1992. Great Lakes Water Quality Initiative Tier II water quality values for protection of aquatic life in ambient water. Support documents. November 23, 1992.

EPA. 1993a. Water quality guidance for the Great Lakes System and correction; Proposed rules. Federal Register. 58(72):20802-21047.

EPA. 1993b. Sediment quality criteria for the protection of benthic organisms - acenaphthene. EPA822-R-93-013. U.S. Environmental Protection Agency, Washington, D.C. 
EPA. 1993c. Sediment quality criteria for the protection of benthic organisms - fluoranthene. EPA822-R-93-012. U.S. Environmental Protection Agency, Washington, D.C.

EPA. 1993d. Great Lakes Water Quality Initiative Criteria documents for the protection of aquatic life in ambient water (February 1993 Draft). PB93-154656. National Technical Information Service. Springfield, VA.

Erben, R. and Z. Pisl. 1993. Acute toxicity for some evaporating aromatic hydrocarbons for freshwater snails and crustacenas. Int. Rev. Gesamten Hydrobiol. 78:161-167.

Ernst, W. R. and E. T. Garside. 1987. Lethal effects of vanadium to two life stages of brook trout Salvelinus fontinalis. Can. J. Zool. 65:628-634.

Ewald, W. G., J. E. French, and M. A. Champ. 1976. Toxicity of Polychlorinated Biphenyls (PCBs) to Euglena gracilis: Cell Population Growth, Carbon Fixation, Chlorophyll Level, Oxygen Consumption, and Protein and Nucleic Acid Synthesis. Bull. Environ. Contam. Toxicol. 16:71-80.

Ewell, W. S., J. W. Gorsuch, R. O. kringle, K. A. Robillard, and R. C. Spiegel. 1986. Simultaneous evaluation of the acute effects of chemicals on seven aquatic speices. Environ. Toxicol. Chem. 5:831-840.

Fargasova, A. 1994. Toxicity of metals on Daphnia magna and Tubifex tubifex. Ecotoxicol. Environ. Saf. 27:210-213.

Finlayson, B. J., and K. M. Verrue. 1985. Toxicities of butoxyethanol ester and propylene glycol butyl ether ester formulations of 2,4-dichlorophenoxy acetic acid (2,4-D) to juvenile salmonids. Arch. Environ. Contam. Toxicol. 14:153-160.

Francis, P. C., D. W. Grothe, and J. C. Scheuring. 1986. Chronic toxicity of 4-nitrophenol to Daphnia magna Straus under static-renewal and flow-through conditions. Bull. Environ. Contam. Toxicol. 36:730-737.

Geiger, J. G. and A. I. Buikema, Jr. 1982. Hydrocarbons depress growth and reproduction of Daphnia pulex (Cladocera). Can. J. Fish. Aquati. Sci. 39:830-836.

Geiger, D. L., C. E. Northcott, D. J. Call, and L. T. Brooke. 1985. Acute toxicities of organic chemicals to fathead minnows (Pimephales promelas), Vol. 2. Center for Lake Superior Environmental Studies, University of Wisconsin, Superior, WI.

Geiger, D. L., D. J. Call, and L. T. Brooke. 1988. Acute toxicities of organic chemicals to fathead minnows (Pimephales promelas), Vol. 4. Center for Lake Superior Environmental Studies, University of Wisconsin, Superior, WI.

Geiger, D. L., L. T. Brooke, and D. J. Call. 1990. Acute toxicities of organic chemicals to fathead minnows (Pimephales promelas), Vol. 5. Center for Lake Superior Environmental Studies, University of Wisconsin, Superior, WI. 
Geiger, D. L., S. H. Poirier, L. T. Brooke, and D. J. Call. 1986. Acute toxicities of organic chemicals to fathead minnows (Pimephales promelas), Vol. 3. Center for Lake Superior Environmental Studies, University of Wisconsin, Superior, WI.

Gersich, F. M. 1984. Evaluation of a static renewal chronic toxicity test method for Daphnia magna straus using boric acid. Environ. Toxicol. Chem. 3:89-94.

Glassi, S., M. Mingazzini, L. Vigano, D. Cesareo, and M. L. Tosato. 1988. Approaches to modeling toxic responses of aquatic organisms to aromatic hydrocarbond. Ecotoxicol. Enviornn. Saf. 16:158-169.

Goettl, J. P., Jr. and P. H. Davies. 1976. Water pollution studies. Federal Aid Project F-33-R-11. Department of Natural Resources, Colorado Division of Wildlife.

Hamelink, J. L., D. R. Buckler, f. L. Mayer, D. U. Palawski, and H. O. Sanders. 1986. Toxicity of fluoridone to aquatic invertebrates and fish. Environ. Toxicol. Chem. 5:97-94.

Hamilton, S. J. 1995. Hazard assessment of inorganics to three endangered fish in the Green River, Utah. Ecotoxicol. Environ. Saf. 30:134-142.

Hamilton. S. J. and K. J. Buhl. 1990. Safety assessment of selected inorganic elements to fry of chinook salmon (Oncorhynchus tshawytscha). Ecotoxicol. Enviorn. Saf. 20:307-324.

Hannah, J. B., J. E. Hose, M. L. Landolt, B. S. Miller, S. P. Felton, and W. T. Iwaoko. 1982. Benzo(a)pyrene-induced morphologic and developmental abnormalities in rainbow trout. Arch. Environ. Contam. Toxicol. 11:727-734.

Hazel, C. R. and S. J. Meith. 1970. Bioassay of king salmon eggs and sac fry in copper solutions. Calif. Fish Game. 2:121-124.

HECD (Health and Criteria Division). 1992. Interim guidance on interpretation and implementation of aquatic life criteria for metals. U.S. Environmental Protection Agency, Washington, D.C.

Hermanutz, R. O., R. H. Mueller, and K. D. Kempfer. 1973. Captan toxicity to fathead minnows (Pimephales promelas), bluegills (Lepomis macrochirus), and brook trout (Salvelinus fontinalis). J. Fish. Res. Board Can. 30:1811-1817.

Hodson, P. V., R. Parisella, B. Blunt, B. Gray, K. L. E. Kaiser. 1991. Quantitative structure-activity relationships for chronic toxicity of phneol, p-chlorophenol, 2,4-dichlorophenol, pentachlorophenol, p-nitrophenol, and 1,2,4-trichlorobenzene to early life stages of rainbow trout (Oncorhynchus mykiss). Can. Tech. Rep. Fish. Aquat. Sci. 1784.

Hodson, P. V., D. G. Dixon, and K. L. E. Kaiser. 1984. Measurement of median lethal dose as a rapid indication of contaminant toxicity to fish. Environ. Toxicol. Chem. 3:243-254.

Holcombe, G. W., D. A. Benoit, E. N. Leonard, and J. M. McKirn. 1976. Long term effects of lead exposure on three generations of brook trout (Salvelinus fontinalis). J. Fish. Res. Board Can. 33:1731-1741. 
Holcombe, G. W., G. L. Phipps, and J. T. Fiandt. 1982. Effects of phenol, 2,4-dimethylphenol,2,4dichlorophenol, and pentachlorophenol on embryo, larval, and early-juvenile fathead minnows (Pimephales promelas). Arch. Environ. Contam. Toxicol. 11(1):73-78.

Holcombe, G. W., G. L. Phipps, and J. T. Fiandt. 1983. Toxicity of selected priority pollutants to various aquatic organisms. Ecotoxicol. Environ. Saf. 7400-7409.

Holcombe, G. W., G. L. Phipps, M. L. Knuth, and T. Felhaber. 1984. The acute toxicity of selected substituted phenols, benzenes and benzoic acid esters to fathead minnows Pimephales promelas. Environ. Pollut. Ser. A Ecol. Biol. 35:367-381.

Holdway, D. A. and J. B. Sprague. 1979. Chronic toxicity of vanadium to flagfish. Water Res. 13:905-910.

Holman, W. F., and K. J. Macek. 1980. An aquatic safety assessment of linear alkylbenzsulfonate (LAS): chronic effects on fathead minnows. Trans. Am. Fish. Soc. 109:122-131.

Holst, L. L. and J. P. Giesy. 1989. Chronic effects of the photoenhanced toxicity of anthracene on Daphnia magna reproduction. Environ. Toxicol. Chem. 8:933-942.

Howe, G. E., L. L. marking, T. D. Bills, J. J. Rach, and F. L. Mayer, Jr. 1994. Effects of water temperature and $\mathrm{pH}$ on toxicity of terbufos, trichlorfon, 4-nitrophenol and 2,4-dinitrophenol to the amphipod Gammarus pseudolimnaeus and rainbow trout (Onchorhynchus mykiss). Environ. Toxicol. Chem. 13:51-56.

Ingersoll, C. G. et al. 1990a. Aluminum and acid toxicity to two strains of brook trout (Salvelinus fontinalis). Can. J. Fish. Aquat. Sci. 47:1641-1648.

Ingersoll, C. G. et al. 1990b. Effects of $\mathrm{pH}$, aluminum, and calcium on survival and growth of eggs and fry of brook trout (Salvelinus fontinalis). Can. J. Fish. Aquat. Sci. 47:1580-1592.

Jarvinen, A. W., M. J. Hoffman, and T. W. Thorslund. 1977. Long-term toxic effects of DDT food and water exposure on fathead minnows (Pimephales promelas). J. Fish. Res. Board Can. 34:2089-2103.

Jarvinen, A. W., B. R. Nordling, and M. E. Henry. 1983. Chronic toxicity of dursban (chlorpyrifos) to the fathead minnow (Pimephales promelas) and the resultant acetylcholinesterase inhibition. Ecotoxicol. Environ. Safety. 7:423-434.

Johnson, W. W. and M. T. Finley. 1980. Handbook of acute toxicity of chemicals to fish and aquatic invertebrates. Resour. Publ. 137, Fish Wildl. Serv., U.S. D.I., Washington, D.C.

Johnston, P. A. 1987. Acute toxicity of inorganic selenium to Daphnia magna (Straus) and the effect of sub-acute exposure upon growth and reproduction. Aquat. Toxicol. 10:335-352.

Karlander, E. P. and R. W. Krauss. 1972. Absorption and toxicity of beryllium and lithium in Chlorella vannielii Shihira and Krauss. Chesapeake Science. 13:245-253.

Kauss, P. B. and T. C. Hutchinson. 1975. The effects of water-soluble petroleum components on the growth of Chlorella vulgaris Beijerinck. Environ. Pollut. 9:157-174. 
Keen, R., and C. R. Baillod. 1985. Toxicity to Daphnia of the end products of wet oxidation of phenol and substituted phenol. Water Res. 19:767-772.

Khangarot, B. S. 1991. Toxicity of metals to a freshwater tubificid worm, Tubifex tubifex. Bull. Environ. Contam. Toxicol. 46:906-912.

Khangarot, B. S., A. Sehgal, and M. K. Bhasin. 1985. Man and biosphere--Studies on the Sikkim Himalayas. Part 5: Acute toxicity of selected heavy metals on the tadpoles of Rana hexadactyla. Acta Hydrochim. Hydrobiol. 13:259-263.

Kimball, G. n.d. The effects of lesser known metals and one organic to fathead minnows [Pimephales promelas] and Daphnia magna. U.S. Environnnental Protection Agency, Duluth, MN.

Kleiner, C. F., R. L. Anderson, and D. K. Tanner. 1984. Toxicity of fenitrothion to fathead minnows (Pimephales promelas) and alternate exposure duration studies with fenitrothion and endosulfan. Arch. Environ. Contam. Toxicol. 13:573-578.

Koenst, W. M., L. L. Smith, Jr., and S. J. Broderius. 1977. Effect of chronic exposure of brook trout to sublethal concentrations of hydrogen cyanide. Environmental Science and Technology 11:883-886.

Könemann, H. 1981. Quantitative structure-activity relationships in fish toxicity studies. Part 1: Relationship for 50 industrial pollutants. Toxicology. 19:209-221.

Kouyoumjian, H. H. and R. F. Uglow. 1974. Some aspects of the toxicity of p,p'-DDT, p,p'-DDE and p,p'-DDD to the freshwater planarian Polycelis felina (Tricladida). Environ. Pollut. 7:103-109.

Krishnakumari, M. K. 1977. Sensitivity of the alga Scenedesmus acutus to some pesticides. Life Sciences. 20:1525-1532.

Kszos, L. A., A. J. Stewart, and P. A. Taylor. 1992. An evaluation of nickel toxicity to Ceriodaphnia dubia and Daphnia magna in a contaminated stream and in laboratory tests. Environ. Toxicol. Chem. 11:1001-1012.

Kühn, R., M. Pattard, K. Pernak, and A. winter. 1989. Results of the harmful effects of selected water pollutants (anilines, phenol, aliphatic compounds) to Daphnia magna. Water Res. 23:495-499.

Kühn, R., M. Pattard, K. Pernak, and A. Winter. 1989. Results of the harmful effects of water pollutants to Daphnia magna in the 21 day reproduction test. Water Res. 23:501-510.

Larsson, L. and J. Tillberg. 1975. Effects of the Commercial Polychlorinated Biphenyl Mixture Aroclor 1242 on Growth, Viability, Phosphate Uptake, Respiration and Oxygen Evolution in Scenedesmus. Physiol. Plant 33:256-260.

Lazareva, L. P. 1985. Changes in biological characteristics of Daphnia magna from chronic action of copper and nickel at low concentrations. Hydrobiol. J. 21(5):59-62.

LeBlanc, G. A. 1980. Acute toxicity of priority pollutants to water flea (Daphnia magna). Bull. Environ. Contam. Toxicol. 24:684-691. 
LeBlanc, G. A. and D. C. Surprenant. 1983. The acute and chronic toxicity of acetone, dimethyl formamide, and triethylene glycol to Daphnia magna (Straus). Arch. Environ. Contam. Toxicol. 12:305-310.

LeBlanc, G. A., J. D. Mastone, A. P. Paradice, B. F. Wilson, H. B. Lockhart, Jr., and K. A. Robillard. 1984. The influence of speciation on the toxicity of silver to fathead minnow (Pimephales promelas). Environ. Toxicol. Chem. 3:37-46.

Leduc, G. 1978. Deleterious effects of cyanide on early life stages of atlantic salmon (Salmo salar). J. Fish. Res. Board Can. 35:166-174.

Lewis, M. A. and L. C. Valentine. 1981. Acute and chronic toxicities of boric acid to Daphnia magna Straus. Bull. Environ. Contam. Toxicol. 27:309-315.

Lima, A. R. et al. 1984. Acute and chronic toxicities of arsenic (III) to fathead minnows, flagfish, daphnids, and an amphipod. Arch. Environ. Contam. Toxicol. 13:595-601.

Lind, D., K. Alto, and S. Chatterton. 1978. Regional copper-nickel study; aquatic toxicology study. Minnesota Environmental Quality Board.

Lock, R. A. C. and A. P. van Overbeeke. 1981. Effects of mercuric chloride and methylmercuric chloride on mucus secretion in rainbow trout, Salmo gairdneri Richardson. Comp. Biochem. Physiol. 69C:67-74.

Luard, E. J. 1973. Sensitivity of Dunaliella and Scenedesmus (Chlorphyceae) to Chlorinated hydrocarbons. Phycologia 12:29-33.

Macek, K. J., K. S. Buxton, S. K. Derr, J. W. Dean, and S. Sauter. 1976a. Chronic toxicity of lindane to selected aquatic invertebrates and fish. EPA-600/3-76-046. U.S. Environmental Protection Agency, Duluth, Minn.

Macek, K. J., M. A. Lindberg, S. Sauter, K. Buxton, and P. A. Costa. 1976b. Toxicity of four pesticides to water fleas and fathead minnows. EPA-600/3-76-099. U.S. Environmental Protection Agency, Duluth, Minn.

McCarthy, J. F. and D. K. Whitmore. 1985. Chronic toxicity of di-n-butyl and di-n-octyl phthalate to Daphnia magna and the fathead minnow. Environ. Toxicol. Chem. 4:167-179.

McCauley, D. J., L. T. Brooke, D. J. Call, and C. A. Lindberg. 1986. Acute and chronic toxicity of aluminum to Ceriodaphnia dubia at various $p H$ 's. Center for Lake Superior Environmental Studies, University of Wisconsin-Superior, Superior, Wis.

McKim, J. M., and D. A. Benoit. 1971. Effects of long-term exposures to copper on survival, growth, and reproduction of brook trout (Salvelinus fontinalis). J. Fish. Res. Board Can. 28:655-662.

McKim, J. M., G. F. Olson, G. W. Holcombe, and E. P. Hunt. 1976. Long-term effects of methylmercuric chloride on three generations of brook trout (Salvelinus fontinalis): toxicity, accumulation, distribution, and elimination. J. Fish. Res. Board Can. 33:2726-2739. 
Martin, T. R. and D. M. Holdich. 1986. The Acute lethal toxicity of heavy metals to peracarid crustaceans (with particular reference to fresh-water Asellids and Gammarids). Water Res. 20:1137-1147.

Mattson, V. R., J. W. Arthur, and C. T. Walbridge. 1976. Acute toxicity of selected organic compounds to fathead minnows. Ecol. Res. Ser. EPA-600/3-76-097, Environ. Res. Lab., U.S. EPA, Duluth, MN.

Mauck, W. L., P. M. Mehrle, and F. L. Mayer. 1978. Effects of the polychlorinated biphenyl Aroclor $^{(1254}$ on growth, survival, and bone development in brook trout (Salvelinus fontinalis). J. Fish. Res. Board Can. 35:1084-1088.

Mayer, F. L., Jr., P. M. Mehrle, Jr., and W. P. Dwyer. 1975. Toxaphene effects on reproduction, growth and mortality of brook trout. EPA-600/3-75-013. U. S. Environmental Protection Agency, Duluth, Minn.

Mayer, F. L., Jr., P. M. Mehrle, H. O. Sanders. 1977. Residue dynamics and biological effects of polychlorinated biphenyls in aquatic organisms. Arch. Environ. Contam. Toxicol. 5:501-511.

Mayer, F. L., Jr., and H. O. Sanders. 1973. Toxicology of phthalic acid esters in aquatic organisms. Environmental Health Perspectives 5:153-157.

Mayer, F. L., Jr. and M. R. Ellersieck. 1986. Manual of acute toxicity: interpretation and data base for 410 chemicals and 66 species of freshwater organisms. Resource Publication 160. U.S. Fish and Wildlife Service, Washington, D.C.

Mayes, M. A., H. C. Alexander, D. L. Hopkins, P. B. Latvaitis. 1986. Acute and chronic toxicity of ammonia to freshwater fish: a site-specific study. Environ. Toxicol. Chem. 5:437-442.

Mehrle, P. M., and F. L. Mayer. 1976. Di-2-ethylhexyl phthalate: residue dynamics and biological effects in rainbow trout and fathead minnows. Trace Subst. Env. Health 10:519-524.

Millemann, R. E., W. J. birge, J. A. Black, R. M. Cushman, K. L. Daniels, P. J. Franco, J. M. Giddings, J. F. McCarthy, and A. J. Stewart. 1984. Comparative acute toxicity to aquatic organisms of components of coal-derived synthetic fuels. Trans. Am. Fish. Soc. 113:74-85.

Moles, A., S. D. Rice, and S. Korn. 1979. Sensitivity of Alaskan freshwater and anadromous fishes to Prudhoe Bay crude oil and benzene. Trans. Am. Fish. Soc. 108:408-414.

Mount, D. I. 1968. Chronic toxicity of copper to fathead minnows (Pimephales promelas Rafinesque). Water Res. 2:215-223.

Mount, D. I. 1982. Memorandum to Charles E. Spehar. U.S. Environmental Protection Agency, Duluth, Minn. June 7.

Mount, D. I., and C. E. Stephan. 1969. Chronic toxicity of copper to the fathead minnow (Pimephales promelas) in soft water. J. Fish. Res. Board Can. 26:2449-2457. 
Munoz, M. J. and J. V. Tarazona. 1993. Synergistic effect of two- and four-component combinations of the polycyclic aromatic hydrocarbons: Phenanthrene, anthracene, naphthalene and acenapthene on Daphnia magna. Bull. Enviorn. Contam. Toxicol. 50:363-368.

Münzinger, A. 1990. Effects of nickel on Daphnia magna during chronic exposure and alterations in the toxicity to generations pre-exposed to nickel. Wat. Res. 24:845-852.

Nebeker, A. V., C. K. McAuliffe, R. Mshar, and D. G. Stevens. 1983. Toxicity of silver to steelhead and rainbow trout, fathead minnows, and Daphnia magna. Environ. Toxicol. Chem. 2:95-104.

Nebeker, A. V., C. Savonen, R. J. Baker, J. K. McCrady. 1984. Effects of copper, nickel, and zinc on the life cycle of the caddisfly Clistoronia magnifica (Limnephilidae). Environ. Toxicol. Chem. 3:645-649.

Nebeker, A. V., C. Savonen, and D. G. Stevens. 1985. Sensitivity of rainbow trout early life stages to nickel chloride. Environ. Toxicol. Chem. 4:233-239.

Nebeker, A. V., and F. A. Puglisi. 1974. Effect of polychlorinated biphenyls (PCBs) on survival and reproduction of Daphnia, Gammarus, and Tanytarsus. Trans. Am. Fish. Soc. 103:722-728.

Nebeker, A. V., F. A. Puglisi, and D. L. DeFoe. 1974. Effect of polychlorinated biphenyl compounds on survival and reproduction of the fathead minnow and flagfish. Trans. Am. Fish. Soc. 103:562-568.

Oris, J. T., J. P. Giesy Jr. 1985. The photoenhanced toxicity of anthracene to juvenile sunfish (Lepomis sp.). Aquat. Toxicol. 6:133-146.

Oseid, D. M., L. L. Smith Jr. 1979. The effects of hydrogen cyanide on Asellus communis and Gammarus pseudolimnaeus and changes in their competitive response when exposed simultaneously. Bull. Environ. Contam. Toxicol. 21:439-447.

OSWER (Office of Solid Waste and Emergency Response). 1996. Ecotox thresholds. ECO Update $3(2): 1-12$.

Palawski, D., J. B. Hunn, and F. J. Dwyer. 1985. Sensitivity of young striped bass to organic and inorganic contaminants in fresh and saline waters. Trans. Am. Fish. Soc. 114:748-753.

Parkhurst, B. R., R. G. Elder, J. S. Meyer, D. A. Sanchez, R. W. Pennak, and W. T. Waller. 1984. An environmental hazard evaluation of uranium in a Rocky Mountain stream. Environ. Toxicol. Chem. 3:113-124.

Passino, D. R. M. and A. J. Novak. 1984. Toxicity of Arsenate and DDT to the Cladoceran Bosmina logirostris. Bull. Environ. contam. Toxicol. 33:325-329.

Passino, D. R. M. and J. M. Kramer. 1980. Toxicity of arsenic and PCBs to fry of deepwater ciscoes (Coregonus). Bull. Environ. Contam. Toxicol. 24:527-534.

Passino, D. R. M and S. B. Smith. 1987. Acute bioassays and hazard evaluation of representative contaminants detected in Great Lakes fish. Enviorn. Toxicol. Chem. 6:901-907. 
Phipps, G. L., G. W. Holcombe, and J. T. Fiandt. 1981. Acute toxicity of phenol and substituted phenols to the fathead minnow. Bull. Environ. Contam. Toxicol. 26:585-593.

Pickering, Q. H. 1974. Chronic toxicity of nickel to the fathead minnow and flagfish. Trans. Am. Fish. Soc. 103:562-568.

Pickering, Q. H. 1980. Chronic toxicity of hexavalent chromium to the fathead minnow (Pimephales promelas). Arch. Environ. Contam. Toxicol. 9:405-413.

Pickering, Q. H. and C. Henderson. 1966. Acute toxicity of some important petrochemicals to fish. J. Water Pollut. Control Fed. 38:1419-1429.

Pickering, Q. H. and M. H. Gast. 1972. Acute and chronic toxicity of cadmium to the fathead minnow (Pimephales promelas). J. Fish. Res. Board Can. 29:1099-1106.

Pickering, Q. H. and W. T. Gilliam. 1982. Toxicity of aldicarb and fonofos to the early life-stage of the fathead minnow. Arch. Environ. Contam. Toxicol. 11:699-702.

Pickering, Q. H., and T. O. Thatcher. 1970. The chronic toxicity of linear allcylate sulfonate (LAS) to Pimephales promelas, Rafinesque. J. Water Pollut. Control Fed. 42:243-254.

Prothro, M. G. 1993. Office of Water Policy and Technical Guidance on Interpretation and Implementation of Aquatic Life Metals Criteria. Memorandum to Water Management Division Directors and Environmental Services Division Directors, Regions I-X, October 1, 1993.

Rai, L. C., J. P. Gaur, H. D. Kumar. 1981. Protective effects of certain environmental factors on the toxicity of zinc, mercury, and methylmercury to Chlorella vulgaris. Environ. Res. 25:250-259.

Randall, T. L. and P. V. Knopp. 1980. Detoxification of specific organic substances by wet oxidation. J. Water Pollut. Control Fed. 52:2117-2130.

Region IV. 1995. Ecological screening values. Ecological Risk Assessment Bulletin No. 2. Waste Management Division, U.S. Environmental Protection Agency Region IV, Atlanta, GA.

Reynolds, J. H., E. J. Middlebrooks, D. B. Porcella, W. J. Grenney. 1975. Effects of temperature on oil refinery waste toxicity. J. Water Poll. Control Fed. 47:2674-2693.

Rhodes, J. E, W. J. Adams, G. R. Biddinger. 1995. Chronic toxicity of 14 phthalate esters to Daphnia magna and rainbow trout (Oncorhynchus mykiss). Environ. Toxicol. Chem. 14:1967-1976.

Richter, J. E., S. F. Peterson, and C. F. Kleiner. 1983. Acute and chronic toxicity of some chlorinated benzenes, chlorinated ethanes, and tetrachloroethylene to Daphnia magna. Arch. Environ. Contam. Toxicol. 12:679-684.

Roghair, C. J., A. Buijze, E. S. E. Yedema, and J. L. M. hermens. 1994. A QSAR for base-line toxicity to the midge Chironomus riparius. Chemosphere 28:989-997.

Sanders, H. O., 1970. Pesticide toxicities to tadpoles of the western chorus frog Peseudacris triseriata and flowler's toad Bufo woodhousii fowleri. Copeia 2:246-251. 
Sanders, H. O. 1969. Toxicity of pesticides to the crustacean Gammarus lacustris. Tech. Paper No. 25, Bur. Sports Fish. Wildl., Fish Wildl. Serv., U.S.D.I.

Sanders, H. O. 1972. Toxicity of some insecticides to four species of malacostracan crustaceans. Tech. Paper No. 66, Bur. Sports Fish. Wildl., Fish Wildl. Serv., U.S.D.I.

Sanders, H. O., F. L. Mayer, Jr., and D. F. Walsh. 1973. Toxicity, residue dynamics, and reproductive effects of phthalate esters in aquatic invertebrates. Environ. Res. 6:84-90.

Sanders, H. O. and O. B. Cope. 1968. The relative toxicities of several pesticides to naiads of three species of stoneflies. Limnol. Oceanogr. 13:112-117.

Sadler, K. and S. Lynam. 1988. The influence of calcium on aluminum-induced changes in the growth rate and mortality of brown trout, Salmo trutta L. J. Fish Biol. 33:171-179.

Sauter, S., K. S. Buxton, K. J. Macek, and S. R. Petrocelli. 1976. Effects exposure to heavy metals on selected freshwater fish. EPA-600/3-76-105. U.S. Environmental Protection Agency, Duluth, Minn.

Seim, W. K., L. R. Curtis, S. W. Blenn, and G. A. Chapman. 1984. Growth and survival of developing steelhead trout (Salmo gairdneri) continuously or intermittently exposed to copper. Can. J. Fish. Aquat. Sci. 41:433-438.

Shubat, P. J., S. H. Poirier, M. L. knuth, and L. T. Brooke. 1982. Acute toxicity of tetrachloroethylene and tetrachloroethylene with dimethylformamide to rainbow trout (Salmo gairdneri). Bull. Environ. Contam. Toxicol. 28:7-10.

Sinley, J. R., J. P. Goettl, Jr., and P. H. Davies. 1974. The effects of zinc on rainbow trout (Salmo gairdneri) in hard and soft water. Bull. Environ. Contam. Toxicol. 12:193-201.

Sloff, W. 1983. Benthic macroinvertebrates and water quality assessment: Some toxicological considerations. Aquat. Toxicol. 4:73-82.

Slonim, A. R and E. E. Ray. 1975. Acute toxicity of beryllium sulfate to salamander larvae (Ambystoma sp.). Bull. Enviorn. Contam. Toxicol. 13:307-312.

Slonim, C. B. and A. R. Slonim. 1973. Effect of water hardness on the tolerance of the guppy to beryllium sulfate. Bull. Environ. Contam. Toxicol. 10:295-301.

Smith, A. D., A. Bharath, C. Mallard, D. Orr, K. Smith, J. A. Sutton, J. Vukmanich, L. S. McCarthy, and G. W. Ozburn. 1991. The acute and chronic toxicity of ten chlorinated organic compounds to the American flagfish (Jordanella floridae). Arch. Enviorn. Contam. Toxicol. 20:94-102.

Smith, L. L., S. J. Broderius, D. M. Oseid, G. L. Kimball, W. M. Koenst, and D. T. Lind. 1979. Acute and chronic toxicity of HCN to fish and invertebrates. EPA-600/3-79-009. U.S. Environmental Protection Agency.

Smith, L. R., T. M. Holsen, N. C. Ibay, R. M. Block, and A. B. de Leon. 1985. Studies on the acute toxicity of fluoride ion to stickleback, fathead minnow, and rainbow trout. Chemosphere 14(9):1383-1389. 
Smith, S. B., J. F. Savino, and M. A. Blouin. 1988. Acute toxicity to Daphnia pulex of six classes of chemical compounds potentially hazardous to Great Lakes aquatic biota. J. Great Lakes Res. 14:394-404.

Snarski, V. M., and G. F. Olson, 1982. Chronic toxicity and bioaccumulation of mercuric chloride in the fathead minnow (Pimephales promelas). Aquat. Toxicol. 2:143-156.

Spehar, R. L. 1976. Cadmium and zinc toxicity to flagfish, Jordanella floridae. J. Fish. Res. Board Can. 33:1939-1945.

Spehar, R. L., J. T. Fiandt, R. L. Anderson, and D. L. DeFoe. 1980. Comparative toxicity of arsenic compounds and their accumulation in invertebrates and fish. Arch. Environ. Contam. Toxicol. 9:53-63.

Spehar, R. L., D. K. Tanner, and B. R. Nordling. 1983. Toxicity of the synthetic pyrethroids, permethrin, and AC 222,705 and their accumulation in early life stages of fathead minnows and snails. Aquat. Toxicol. 3:171-182.

Stalling, D. L. and F. L. Mayer, Jr. 1972. Toxicities of PCBs to fish and environmental residues. Environ. Health Perspect. 1:159-164.

Steeman-Nielsen, E. and S. Wium-Andersen. 1970. Copper ions as poison in the sea and freshwater. Marine Biology. 6:93-97.

Stephan, C. E. 1991. Letter to Mr. Jim Grant. Michigan Department of Natural Resources.

Stephan, C. E., D. I. Mount, D. J. Hansen, J. H. Gentile, G. A. Chapman, and W. A. Brungs. 1985. Guidelines for deriving numerical national water quality criteria for the protection of aquatic organisms and their uses. PB85-227049. National Technical Information Service, Springfield, Va.

Stephan, C. E., and J. R. Rogers. 1985. Advantages of using regression analysis to calculate results of chronic toxicity tests, pp. 328-339 in Aquatic Toxicology and Hazard Assessment: Eighth Symposium, R. C. Bahner and D. J. Hansen (eds.), American Society for Testing and Materials, Philadelphia.

Stephan, E. E. and R. J. Erickson. n.d. Guidelines for deriving an aquatic life pesticide concentration. U.S. Environmental Protection Agency, Environmental Research Laboratory, Duluth, MN, unpublished document.

Stevens, D. G. and G. A. Chapman. 1984. Toxicity of trivalent chromium to early life stages of steelhead trout. Environ. Toxicol. Chem. 3:125-133.

Streufert, J. M., J. R. Jones, and H. O. Sanders. 1980. Toxicity and biological effects of phthalate esters on midges (Chironomus plumosus). Trans. Mo. Acad. Sci. 14:33-40.

Suter, G. W. II. 1989. Ecological endpoints, pp. 2-1-2-28, in Ecological Assessment of Hazardous Waste Sites: A Field and Laboratory Reference Document. EPA 600/3-89/013. W. Warren-Hicks, B. R. Parkhurst, and S. S. Baker, Jr. (eds.). Corvallis Environmental Research Laboratory, Oregon. 
Suter, G. W., II, M. A. Futrell, G. A. Kerchner. 1992. Toxicological benchmarks for screening of potential contaminants of concern for effects on aquatic biota on the Oak Ridge Reservation, Oak Ridge, Tennessee. ORNL/ER-139. Oak Ridge National Laboratory.

Suter, G. W., II, A. E. Rosen, E. Linder, and D. F. Parkhurst. 1987. End points for responses of fish to chronic toxic exposures. Environ. Toxicol. Chem. 6:793-809.

Suter, G. W., II. 1992. Ecological Risk Assessment. Lewis Publishers, Chelsea, MI.

Suter, G. W., II, A. Redfearn, R. K. White, and R. A. Shaw. 1992. Approach and strategy for performing ecological risk assessments for the Department of Energy Oak Ridge Field Office Environmental Restoration Program. ES/ER/TM-33. Environmental Restoration Division, Oak Ridge National Laboratory, Oak Ridge, TN.

Thompson, R. S., and N. G. Carmichael. 1989. 1,1,1-Trichloroethane: medium-term toxicity to carp, daphnids, and higher plants. Ecotox. Environ. Safety 17:172-182.

Thurston, R.V., R. C. Russo, E. L. Meyn, and R. K. Zajdel. 1986. Chronic toxicity of ammonia to fathead minnows. Trans. Amer. Fish. Soc. 115:196-207.

Trucco, R. G., F. R. Engelhardt, and B. Stacey. 1983. Toxicity, accumulation and clearance of aromatic hydrocarbons in Daphnia pulex. Environ. Pollut. Ser. A. Ecol. Biol. 31:191-202.

van den Dikkenberg, R. P., H. H. Canton, L. A. M. Mathijssen-Spiekman, and C. J. Roghair. 1989. The usefulness of gasterosteus aculeatus-the three-spined stickleback-as a test organism in routine toxicity testing. Rep. No. 718625003, Natl. Inst. Public Health Environ. Protection, Bilthoven, the Netherlands.

Van der Schalie, W. H. 1983. The acute and chronic toxicity of 3,5-dinitroaniline, 1,3-dinitrobenzene, and 1,3,5-trinitrobenzene to freshwater aquatic organisms. Technical Report 8305. U.S. Army Medical Bioengineering Research and Development Laboratory, Fort Detrick, Frederick, MD.

Van Leeuwen, C. J. and H. Maas. 1985. The aquatic toxicity of 2,6-dichlorobenzamide (BAM), a degradation product of the herbicide dichlobenil. Environ. Pollut. Ser. A. 37:105-115.

Van Leeuwen, C. J., J. L. Maas-Diepeveen, G. Niebeek, W. H A. Vergouw, P. S. Griffioen, and M. W. Luijken. 1985. Aquatic toxicological aspects of dithiocarbamates and related compounds. I. Short-term toxicity tests. Aquat. Toxicol. 7:145-164.

Vareille-Morel, C. and J. Debord. 1990. Sensibilité du Mollusque prosobranche Potamopyrgus jenkinsi Smith à l'action de chlorures métalliques $\left(\mathrm{ZnCl}_{2}, \mathrm{BaCl}_{2}, \mathrm{CuCl}_{2}\right)$ et d'un molluscicide de synthèse, la N-tributyl-morpholine. Ann Rech. Vét. 21:111-118.

Veith, G. D., D. J. Call, L. T. Brooke. 1983. Estimating the acute toxicity of narcotic industrial chemicals to fathead minnows, pp. 90-97, in Aquatic Toxicol. and Hazard Assessment: Sixth Symposium. W. E. Bishop, R. D. Cardwell, and B. B. Heidolph (eds.), ASTM STP 802, Philadelphia.

Veith, G. D., D. J. Call, and L. T. Brooke. 1983. Structure-toxicity relationships for the fathead minnow, Pimephales promelas: narcotic industrial chemicals. Can. J. Fish. Aquat. Sci. 40:743-748. 
Villar, D., M. H. Li, and D. J. Schaeffer. 1993. Toxicity of organophosphorus pesticides to Dugesia dorotocephala. Bull. Environ. Contam. Toxicol. 51:80-87.

Vincent, M., J. Debord, and B. Penicaut. 1986. Comparative studies on the toxicity of metal chlorides and of a synthetic organic molluscicide, N-trityl-Morpholine, upon two aquatic amphipods: Gammarus pulex and Echinogammarus berilloni. Ann. Rech. Vét. 17:441-446.

Vocke, R. W., K. L. Sears, J. J. O'Toole, R. B. Wildham. 1980. Growth responses of selected freshwater algae to trace elements and scrubber ash slurry generated by coal-fired power plants. Water Res. 14:141-150.

Walbridge, C. T., J. T. Fiandt, G. L. Phipps, and G. W. Holcombe. 1983. Acute toxicity of ten chlorinated aliphatic hydrocarbons to the fathead minnow (Pimephales promelas). Arch. Environ. Contam. Toxicol. 12:661-666.

Wallen, I. E., W. C. Greer, and R. Lasater. 1957. Toxicity to Gambusia affinis of certain pure chemicals in trubid waters. Sewage Ind. Wastes 29:695-711.

Ward, T. J., and R. L. Boeri. 1991a. Early Life Stage Toxicity of Di-n-Butyl Phthalate (DnBP) to the rainbow Trout (Oncorhunchus mukiss) Under Flow-Through Conditions. 9102-CMA. Chemical Manufacturers Association, Washington, D.C.

Waste Management Division. 1995. Ecological screening values, Ecological Risk Assessment Bulletin No. 2. U.S. Environmental Protection Agency Region IV. Atlanta, Georgia.

Williams, P.L. and D.B.Dusenbery. 1990. Aquatic toxicity testing using the nematode, Caenorhabditis elegans. Environ. Toxicol. Chem. 9:1285-1290

Woodward, D. F., A. M. Farag, M. E. Mueller, E. E. Little, F. A. Vertucci. 1989. Sensitivity of endemic Snake River cutthroat trout to acidity and elevated aluminum. Trans. Amer. Fish. Soc. 118:630-643.

Ziegenfuss, P. S., W. J. Renaudette, and W. J. Adams. 1986. Methodology for assessing the acute toxicity of chemicals sorbed to sediments: Testing the equilibrium partitioning theory. in T. M. Poston and R. Purdy (eds.), Aquatic Toxicology and Environmental Fate, Ninth Volume: ASTM, Philadelphia, PA. 
Appendix A

\section{DATA USED FOR TIER II CALCULATIONS}



Table A.1. Data and calculated results for derivation of Tier II values (all values in $\mu \mathrm{g} / \mathrm{l}$ ). Requirements are listed in App. B.2; other terms are defined in the text

\begin{tabular}{|c|c|c|c|c|c|c|c|}
\hline Compound & Genus/species & Requirement & Endpoint & Concentration & GMAV $^{b}$ & A-C Ratio ${ }^{\mathrm{C}}$ & Reference \\
\hline \multirow{21}{*}{ Arsenic V } & & & NORGANIC & & & & \\
\hline & Bosmina longirostris & 4 & EC50 & 850 & 850 & & Passino and Novak, 1984 \\
\hline & Daphmia pulex & 4 & LC50 & 3,600 & 3,600 & & Jurewicz and Buikema, 1980 \\
\hline & Gambusia affinis & 2,3 & LC50 & 49,000 & 49,000 & & Jurcwicz and Buikema, 1980 \\
\hline & Morone saxatilis & 2,3 & LC50 & 40,500 & & & Palawski et al., 1985 \\
\hline & Morone saxatilis & 2,3 & LC50 & 30,500 & 35,150 & & Palawski ct al., 1985 \\
\hline & Oncorhynchus kisulch & 1 & LC50 & 43,600 & & & Buhl and Hamilton, 1990 \\
\hline & Oncorhynchus kisuch & 1 & LC50 & 58,500 & & & Buhl and Hamilton, 1990 \\
\hline & Oncorhynchus mykiss & 1 & LC50 & 28,000 & & & Palawski et al., 1985 \\
\hline & Oncorhynchus mykiss & 1 & LC50 & 67,500 & 46,860 & & Buhl and Hamilton, 1990 \\
\hline & Plmephales promelas & 2,3 & LC50 & 42,000 & & & Palawski et al., 1985 \\
\hline & Pimephales promelas & 2,3 & LC50 & 25,600 & 32,790 & & DeFoe, 1982 \\
\hline & Pimephales promelas & & $\mathrm{CV}$ & 892 & & 28.7 & DeFoe, 1982 \\
\hline & Thymmallus arcticus & 1 & LC50 & 5,020 & & & Buhl and Hamilton, 1990 \\
\hline & Thymallus arcticus & 1 & LC50 & 5,500 & 5,255 & & Buhl and Hamilton, 1990 \\
\hline & Tubifex tubijex & 7,8 & LC50 & 127,360 & 127,360 & & Fargasova, 1994 \\
\hline & & & & & Tier II & arameters & Tier II Values \\
\hline & & & & & & FAVF & 12.9 \\
\hline & & & & & & SAV & 65.89 \\
\hline & & & & & & SACR & 20.95 \\
\hline & & & & & & SCV & 3.1 \\
\hline
\end{tabular}


Table A.1. (continued)

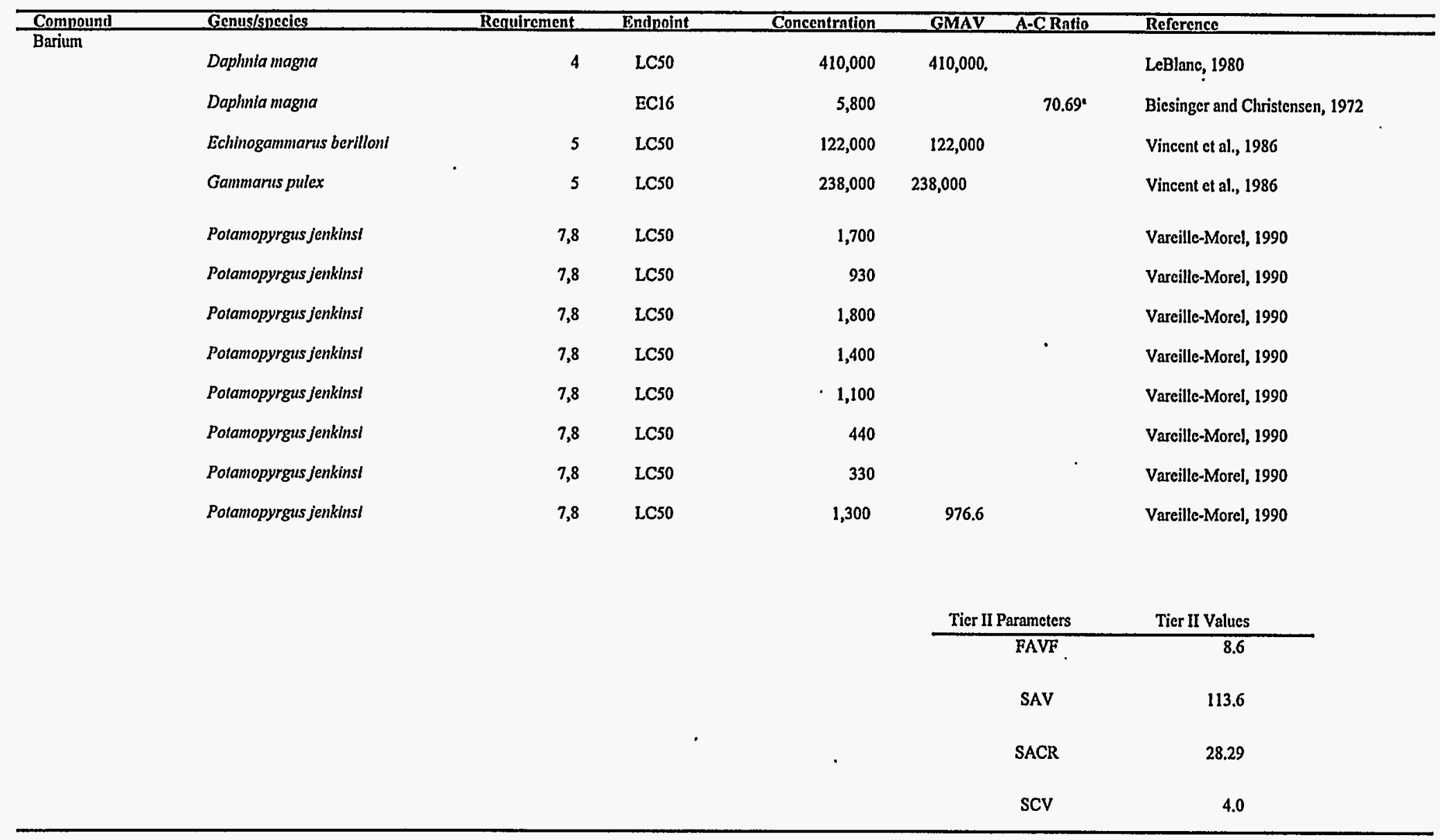

-In the absence of any experimental value, EC16 is used to calculate an A-C ratio. 
Table A.1. (continued)

\begin{tabular}{|c|c|c|c|c|c|c|c|}
\hline Compound & Genus/species & Requirement & Endpoint & Concentration & GMAV & A-C.Catio & Reference \\
\hline \multirow[t]{25}{*}{ Beryllium } & Asellus intermedius & 5 & LC50 & 10,000 & 10,000 & & Ewcll ct al., 1986 \\
\hline & Dugesia tigrina & 7,8 & LC50 & 10,000 & 10,000 & & Ewell ct al., 1986 \\
\hline & Gammarus fasciatus & 5 & LC50 & 700 & 700 & & Ewell et al., 1986 \\
\hline & Helisoma trivolvis & 7,8 & LC50 & 10,000 & 10,000 & & Ewell et al., 1986 \\
\hline & Lumbriculus variegalus & 7,8 & LC50 & 10,000 & 10,000 & & Ewell et al., 1986 \\
\hline & Pimephales promelas & 2,3 & LC50 & 10,000 & 10,000 & & Ewcll et al., 1986 \\
\hline & Ambystoma maculatum & 2,3 & LC50 & 3,150 & & & Slonim and Ray, 1975 \\
\hline & Ambystoma maculatum & 2,3 & LC50 & 18,200 & & & Slonim and Ray, 1975 \\
\hline & Ambystoma maculatumt & 2,3 & LC50 & 8,020 & & & Slonim and Ray, 1975 \\
\hline & Ambystoma maculatum & 2,3 & LC50 & 8,320 & & & Slonim and Ray, 1975 \\
\hline & Ambysloma opacum & 2,3 & LC50 & 3,150 & 4,977 & & Slonim and Ray, 1975 \\
\hline & Cacnorhabdills elegans & 7,8 & LC50 & 140 & 140 & & Williams and Dunsenbery, 1990 \\
\hline & Carassius auratus & 2,3 & LC50 & 55,900 & 55,900 & & Cardwell et al., 1976 \\
\hline & Daphnia magna & 4 & EC50 & 2,410 & & & Kimball n.d. \\
\hline & Daphmla magna & 4 & EC50 & 2,450 & 2,430 & & Kimball n.d. \\
\hline & Daphmia magna & & $\mathrm{CV}$ & 5.267 & & 461.4 & Kimball n.d. \\
\hline & Jordanella floridae & 2,3 & LC50 & 46,300 & & & Cardwell et al., 1976 \\
\hline & Jordanella floridae & 2,3 & LC50 & 41,100 & & & Cardwell et al., 1976 \\
\hline & Jordanella florldae & 2,3 & LC50 & 41,100 & 42,760 & & Cardwell et al., 1976 \\
\hline & PImcphales promelas & 2,3 & LC50 & 37,900 & & & Cardwell et al., 1976 \\
\hline & PImephales promelas & 2,3 & LC50 & 17,900 & & & Kimball n.d. \\
\hline & PImcphales promelas & 2,3 & LC50 & 17,500 & 22,810 & & Kimball n.d. \\
\hline & Poecilla rellculata & 2,3 & LC50 & 1,330 & & . & Slonim and Slonim, 1973 \\
\hline & Poecilla reliculata & 2,3 & LC50 & 160 & & & Slonim and Slonim, 1973 \\
\hline & Poecilia reliculata & 2,3 & LC50 & 190 & & & Slonim and Slonim, 1973 \\
\hline
\end{tabular}


Table A.1. (continued)

\begin{tabular}{|c|c|c|c|c|c|c|}
\hline Compound & $\begin{array}{l}\text { Genis/species } \\
\text { Poecilla reliculata }\end{array}$ & $\frac{\text { Requirement }}{2,3}$ & $\frac{\text { Endnoint }}{\text { LCS0 }}$ & $\frac{\text { Consentration }}{1,330}$ & $\frac{\text { GMAV A-CRatio }}{343.2}$ & $\begin{array}{l}\text { Reference } \\
\text { Slonim and Slonim, } 1973\end{array}$ \\
\hline & Tubifax Inblfax & 7,8 & EC50 & 10,250 & 10,250 & Khangarot, 1991 \\
\hline & & & & & Tier II Parameters & Tier II Values \\
\hline & & & & & FAVF & 4.0 \\
\hline & & & & & SAV & 35 \\
\hline & & & & & SACR & 52.88 \\
\hline & & & & & SCV & 0.66 \\
\hline
\end{tabular}


Table A.1. (continued)

\begin{tabular}{|c|c|c|c|c|c|c|c|}
\hline Compound & Genus/species & Requirement & Endnoint & Concentration & GMAV & A-CRatio & Reference \\
\hline \multirow[t]{18}{*}{ Boron } & Daphmia magna & 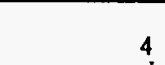 & LC50 & 133,000 & & & Gersich, 1984 \\
\hline & Daphria magra & & $\mathrm{cV}$ & 9,330 & & & Gersich, 1984 \\
\hline & Daplmia magna & 4 & LC50 & 226,000 & 173,400 & & Lewis and Valentine, 1981 \\
\hline & Daphmia magna & & $\mathrm{CV}$ & 8,832 & & $19.10^{\circ}$ & Levis and Valentine, 1981 \\
\hline & Plychocheilus lucius & 2,3 & LC50 & 279 & & & Hamilton, 1995 \\
\hline & Ptychochellus lucius & 2,3 & LC50 & $>100$ & & & Hamilton, 1995 \\
\hline & Plychocheilus lucius & 2,3 & LC50 & 527 & 383.4 & & Hamilton, 1995 \\
\hline & Xyrauchen texamus & 2,3 & LC50 & $>100$ & & & Hamilton, 1995 \\
\hline & Xyrauchen texanus & 2,3 & LC50 & 233 & & & Hamilton, 1995 \\
\hline & Xyrauchen texanus & 2,3 & LC50 & 279 & 255.0 & & Hamilton, 1995 \\
\hline & Gila elegans & 2,3 & LC50 & $>100$ & & & Hamilton, 1995 \\
\hline & Gila elegans & 2,3 & LC50 & 280 & & & Hamilton, 1995 \\
\hline & Glla clegans & 2,3 & LC50 & 552 & 393.1 & & Hamilton, 1995 \\
\hline & & & & & Tier II & arameters & Tier II Values \\
\hline & & & & & & FAVF & 8.6 \\
\hline & & & & & & SAV & 29.65 \\
\hline & & & & & & SACR & 18.29 \\
\hline & & & & & & SCV & 1.6 \\
\hline
\end{tabular}

- The A.C Ratio for D. magna is the geometric mean of A-C Ratios from Gersich, 1987 and Lewis and Valentine, 1981. 
Table A.1. (continued)

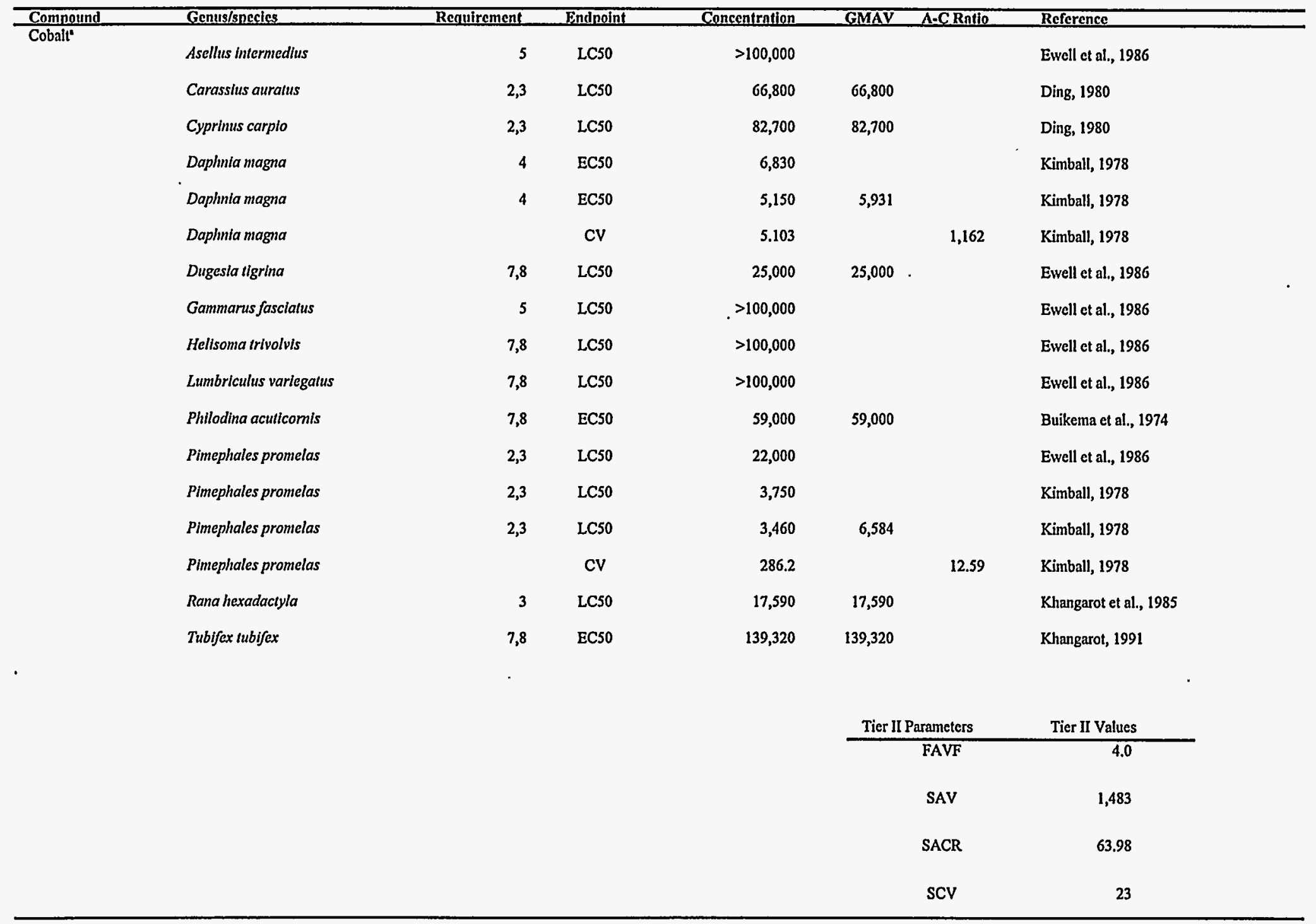

- All data are for cobalt II. 
Table A.1. (continued)

\begin{tabular}{|c|c|c|c|c|c|c|c|}
\hline Compound & Genus/species & Requirement & Endpoint & Concentration & GMAV & A-CRatio & Reference \\
\hline \multirow[t]{12}{*}{ Lithium } & Plychocheilus lucius & 2,3 & LC50 & 28,000 & & & Hamilton, 1995 \\
\hline & Ptychocheilus lucius & 2,3 & LC50 & 41,000 & 33,880 & & Hamilton, 1995 \\
\hline & Xyrauchen texamus & 2,3 & LC50 & 53,000 & & & Hamilton, 1995 \\
\hline & Xyrauchen texanus & 2,3 & LC50 & 186,000 & 99,290 & & Hamilton, 1995 \\
\hline & Gila elegans & 2,3 & LC50 & 62,000 & & & Hamilton, 1995 \\
\hline & Gila elegans & 2,3 & LC50 & 65,000 & 63,480 & & Hamilton, 1995 \\
\hline & Tubifex tufffex & 7,8 & EC50 & 9,340 & 9,340 & & Khangarto, 1991 \\
\hline & & & & & Tier II & arameters & Tier II Values \\
\hline & & & & & & FAVF & 36.2 \\
\hline & & & & & & SAV & 258.0 \\
\hline & & & & & & SACR & 17.9 \\
\hline & & & & & & SCV & 14 \\
\hline
\end{tabular}


Table A.1. (continued)

\begin{tabular}{|c|c|c|c|c|c|c|c|}
\hline \multirow{13}{*}{ Manganese $e^{\prime}$} & Genus/snecies & Requirament & Endnoint & Concentration & GMAV & A-CRntio & Reference \\
\hline & Asellus aquaticus & 5 & ECso & 333,000 & 333,000 & & Martin and Holdich, 1986 \\
\hline & Crangonyx pseudogracilis & 5 & EC50 & 694,000 & 694,000 & & Martin and Holdich, 1986 \\
\hline & Daplmiä magna & 4 & EC50 & 19,500 & & & Kimball n.d. \\
\hline & Daphmia magna & 4 & EC50 & 19,200 & 19,350 & & Kimball n.d. \\
\hline & Pintephales promelas & 2,3 & LC50 & 30,600 & & . & Kimball n.d. \\
\hline & Pimephales promelas & 2,3 & LC50 & 36,900 & 33,600 & & Kimball n.d. \\
\hline & Pimephitales promelas & & $\mathrm{CV}$ & 1,775 & & 18.93 & Kimball n.d. \\
\hline & & & & & Tier II & arameters & Tier II Values \\
\hline & & . & & & & FAVF & 8.6 \\
\hline & & & & & & SAV & 2,250 \\
\hline & & & & & & SACR & 18.24 \\
\hline & & & & & & SCV & 120 \\
\hline
\end{tabular}

- All data are for manganese II. 
Table A.1. (continued)

\begin{tabular}{|c|c|c|c|c|c|c|}
\hline \multirow{10}{*}{$\begin{array}{l}\text { Compound } \\
\text { Mercury, methyl }\end{array}$} & Genus/species & Requirement & Endpoint & Concentration & A-CRatio & Reference \\
\hline & Oncorlyynchus mykiss & 1 & LC50 & 24 & 24 & Lock and van Overbecke, 1981 \\
\hline & Salvelinus fontinalis & 1 & LC50 & 65 & & McKim et al., 1976 \\
\hline & Salvelinus fontinalis & 1 & LC50 & 84 & 74 & McKim ct al., 1976 \\
\hline & Salvelinus fontinalis & & $\mathrm{CV}$ & 0.5193 & 142.3 & McKim et al., 1976 \\
\hline & & & & & Tier II Parameters & Tier II Values \\
\hline & & & & & FAVF & 242 \\
\hline & & & & & SAV & 0.09917 \\
\hline & & & & & SACR & 35.72 \\
\hline & & & & & SCV & 0.0028 \\
\hline
\end{tabular}


Table A.1. (continued)

\begin{tabular}{|c|c|c|c|c|c|c|c|}
\hline \multirow{10}{*}{$\frac{\text { Compound }}{\text { Molybdenum" }}$} & Genus/snccies & Requirement & Endpoint & Concentration & GMAV & A-CRntio & Refcrence \\
\hline & Daphmia magna & 4 & LC50 & 203,200 & & & Kimball n.d. \\
\hline & Daphia magna & 4 & LC50 & 210,300 & 206,700 & & Kimball n.d. \\
\hline & Daplmia magna & & $\mathrm{CV}$ & 877.8 & & 235.5 & Kimball n.d. \\
\hline & Pimephales promelas & 2,3 & LC50 & 628,000 & 628,000 & & Kimball n.d. \\
\hline & & & & & Tier II & Parameters & Tier II Values \\
\hline & & & & & & FAVF & 13.2 \\
\hline & & & & & & SAV & 15,660 \\
\hline & & & & & & SACR & 42.26 \\
\hline & & & & & & SCV & 370 \\
\hline
\end{tabular}

- All tests are for molybdenum VI. 
Table A.1. (continued)

\begin{tabular}{|c|c|c|c|c|c|c|c|}
\hline & Genus/species & Requirement & Endpoint & Concentration & GMAV & $\overline{A-C \text { Ratio }}$ & Reference \\
\hline \multirow[t]{9}{*}{ Strontium } & Daplnia magna & 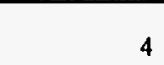 & LC50 & 125,000 & 125,000 & & Biesinger and Christensen, 1972 \\
\hline & Daphnia magna & & EC16 & 42,000 & & $2.98^{\circ}$ & Biesinger and Christensen, 1972 \\
\hline & Tubifex tubijex & 7,8 & EC50 & 240,800 & 240,800 & & Khangarot, 1991 \\
\hline & Cacnorhabditis elegans & 7,8 & LC50 & 465,000 & 465,000 & & Williams and Dusenbery, 1990 \\
\hline & & & & & Tier II & arameters & Tier II Values \\
\hline & & & & & & FAVF & 8.6 \\
\hline & & & & & & SAV & 14,530 \\
\hline & & & & & & SACR & 9.85 \\
\hline & & & & & & scV & 1,500 \\
\hline
\end{tabular}

'In the absence of any experimental chronic values, ECI6 is used to calculate an A-C Ratio. 
Table A.1. (continued)

\begin{tabular}{|c|c|c|c|c|c|c|c|}
\hline \multirow{16}{*}{ Thallium² } & Genus/speciess & Requirement & Endnoint & Concentration. & GMAV & A.CRatio & Reference \\
\hline & Daphlmla magna & 4 & EC50 & 880 & & & Kimball, n.d. \\
\hline & Daphmia magua & 4 & - EC5O & 930 & 905.0 & & Kimball, n.d. \\
\hline & Daphmla magıa & & $\mathrm{cV}$ & 134.5 & & 6.724 & Kimball, n.d. \\
\hline & Cyprinodon variegatus & & LC50 & $20,900^{\circ}$ & & & EPA, 1978 \\
\hline & Cyprinodon variegalus & & $\mathrm{CV}$ & 6,010 & & 3.478 & $\mathrm{EPA}, 1978$ \\
\hline & Lepomis macrochirus & 2,3 & LC50 & 120,000 & & & Buccafusco et al., 1981 \\
\hline & Lepomis macrochirus & 2,3 & LC50 & 132,000 & 125,900 & & Dawson et al., 1977 \\
\hline & PImephales promelas & 2,3 & LC50 & 1,810 & & & Kimball, n.d. \\
\hline & Pimephales promelas & 2,3 & LC50 & 1,780 & 1,795 & & Kimball, n.d. \\
\hline & PImephales promelas & & CV & 56.92 & & 31.53 & Kimball, n.d. \\
\hline & & & & & Tier II & arameters & Tier II Values \\
\hline & & & & & & FAVF & 8.6 \\
\hline & & & & & & SAV & 105.2 \\
\hline & & & & & & SACR & 9.034 \\
\hline & & & & & & SCV & 12 \\
\hline
\end{tabular}

- All data are for thallium I.

- Acute value of $C$. variegalus, a saltwater species, is used for SACR calculation only. 
Table A.1. (continued)

\begin{tabular}{|c|c|c|c|c|c|c|c|}
\hline \multirow{8}{*}{$\begin{array}{l}\text { Compound } \\
\text { Tin }^{2}\end{array}$} & Genus/species & Requirement & Endpoint & Concentration & GMAY & A-CRatio & Reference \\
\hline & Daphinia magna & 4 & LCSO & 55,000 & 55,000 & & Biesinger and Christensen, 1972 \\
\hline & Daplmia magna & & $\mathrm{ECl} 6^{\mathrm{b}}$ & 350 & & 157.1 & Biesinger and Christensen, 1972 \\
\hline & & & & & Ticr Il & Parameters & Tier II Values \\
\hline & & & & & & FAVF & 20.5 \\
\hline & & & & & & SAV & 2,683 \\
\hline & & & & & & SACR & 36.93 \\
\hline & & & & & & SCV & 73 \\
\hline
\end{tabular}

- All data are for tin II.

- In the absence of any experimental chronic values, EC16 is used to calculate an A-C Ratio. 
Table A.1. (continued)

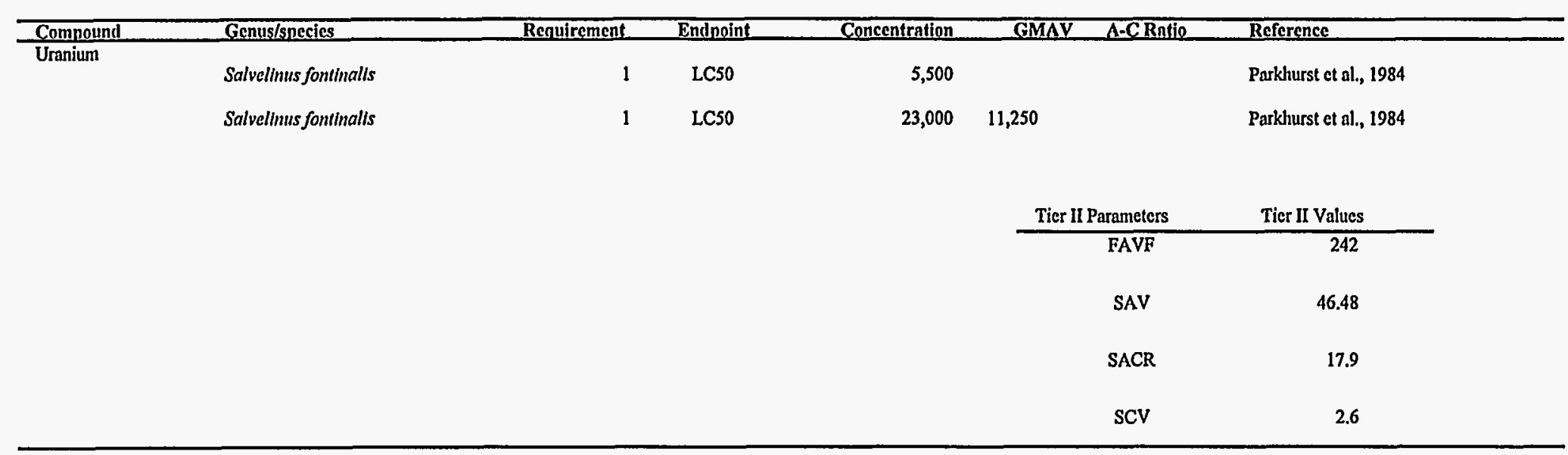


Table A.1. (continued)

\begin{tabular}{|c|c|c|c|c|c|c|c|}
\hline \multirow{24}{*}{$\begin{array}{l}\text { Compound } \\
\text { Vanadium }\end{array}$} & Genus/snecies & Reguirement & Endpoint & Concentration & GMAV & A.C.Ratio & Reference \\
\hline & Daphnia magna & 4 & EC50 & 1,580 & & & Kimball, n.d. \\
\hline & Daphnia magna & 4 & EC50 & 1,460 & & & Kimball, n.d. \\
\hline & Daphnia magna & 4 & EC50 & 3,800 & & & Bensen \&Neven, 1987 \\
\hline & Daphmia magna & 4 & EC50 & 2,900 & & & Bensen \&Neven, 1987 \\
\hline & Daphnia magna & 4 & EC50 & 3,900 & & & Bensen \&Neven, 1987 \\
\hline & Daphmia magna & 4 & EC50 & 3,600 & & & Bensen \&Neven, 1987 \\
\hline & Daphmia magna & 4 & ECs0 & 3,300 & 2,746 & & Bensen \&Neven, 1987 \\
\hline & Daplmia magna & & $\mathrm{cV}$ & 1900 & & $2^{b}$ & Bensen \&Neven, 1987 \\
\hline & Gala elegans & 2,3 & LC50 & 8,800 & & & Hamilton, 1995 \\
\hline & Gala elegans & 2,3 & LC50 & 4,000 & & & Hamilton, 1995 \\
\hline & Gala clegans & 2,3 & LC50 & 3,000 & 4,727 & & Hamilton, 1995 \\
\hline & Jordanella floridae & 2,3 & LC50 & 11,200 & 11,200 & & Holdway and Sprague, 1979 \\
\hline & Jordanella floridac & & $\mathrm{CV}$ & 83.49 & & 134.1 & Holdway and Sprague, 1979 \\
\hline & Oncorhynchus tshowyytscha & 1 & LC50 & 16,500 & 16,500 & & Hamilton and Buhl, 1990 \\
\hline & Pimephales promelas & 2,3 & LC50 & 1,800 & & & Kimball, n.d. \\
\hline & PImephales promelas & 2,3 & LC50 & 1,900 & 1,850 & & Kimball, n.d. \\
\hline & Pimephales promelas & & CV & 169.7 & & 10.90 & Kimball, n.d. \\
\hline & Ptychochellus lucius & 2,3 & LC50 & 7,800 & & & Hamilton, 1995 \\
\hline & Ptychocheilus lucius & 2,3 & LC50 & 3,800 & & & Hamilton, 1995 \\
\hline & Ptychochellus lucius & 2,3 & LC50 & 4,300 & 5,032 & & Hamilton, 1995 \\
\hline & Salvelinus fontinalis & 1 & LC50 & 7,000 & & & Ernst and Garside, 1987 \\
\hline & Salvelinus fontlinalis & 1 & LC50 & 15,000 & 10,250 & & Emst and Garside, 1987 \\
\hline & Xyrauchen texanus & 2,3 & LC50 & 5,300 & & & Hamilton, 1995 \\
\hline
\end{tabular}


Table A.1. (continued)

\begin{tabular}{|c|c|c|c|c|c|c|}
\hline \multirow[t]{8}{*}{ Compound } & Genus/species & Reruirement & Endnoint & Concentration & A-CRntio & Reference \\
\hline & Xyrauchen texanus & 2,3 & LC50 & 2,200 & & Hamillon, 1995 \\
\hline & Xyrauchen texanus & 2,3 & LC50 & 4,600 & 3,770 & Hamilton, 1995 \\
\hline & & & & & Tier II Parameters & Tier II Values \\
\hline & & & & & FAVF & 6.5 \\
\hline & & & & & SAV & 284.6 \\
\hline & & & & & SACR & 14.29 \\
\hline & & & & & scV & 20 \\
\hline
\end{tabular}

- All data are for vanadium $V$.

' Since the experimental A-C Ratio is less than 2, the A-C Ratio of $D$. magna is et to 2 (Stephan et al., 1985). 
Table A.1. (continued)

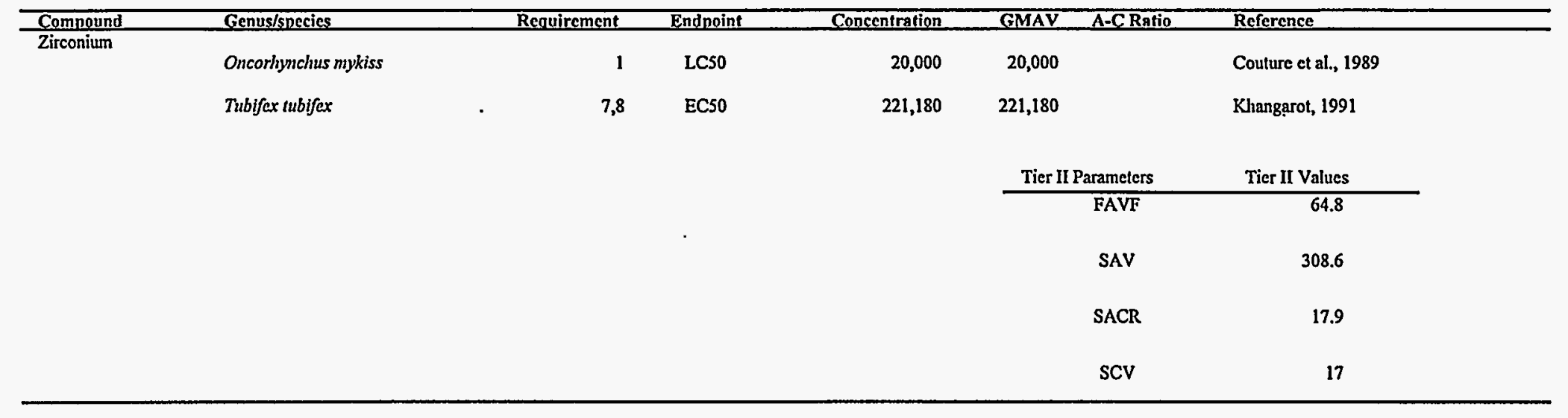


Table A.1. (continued)

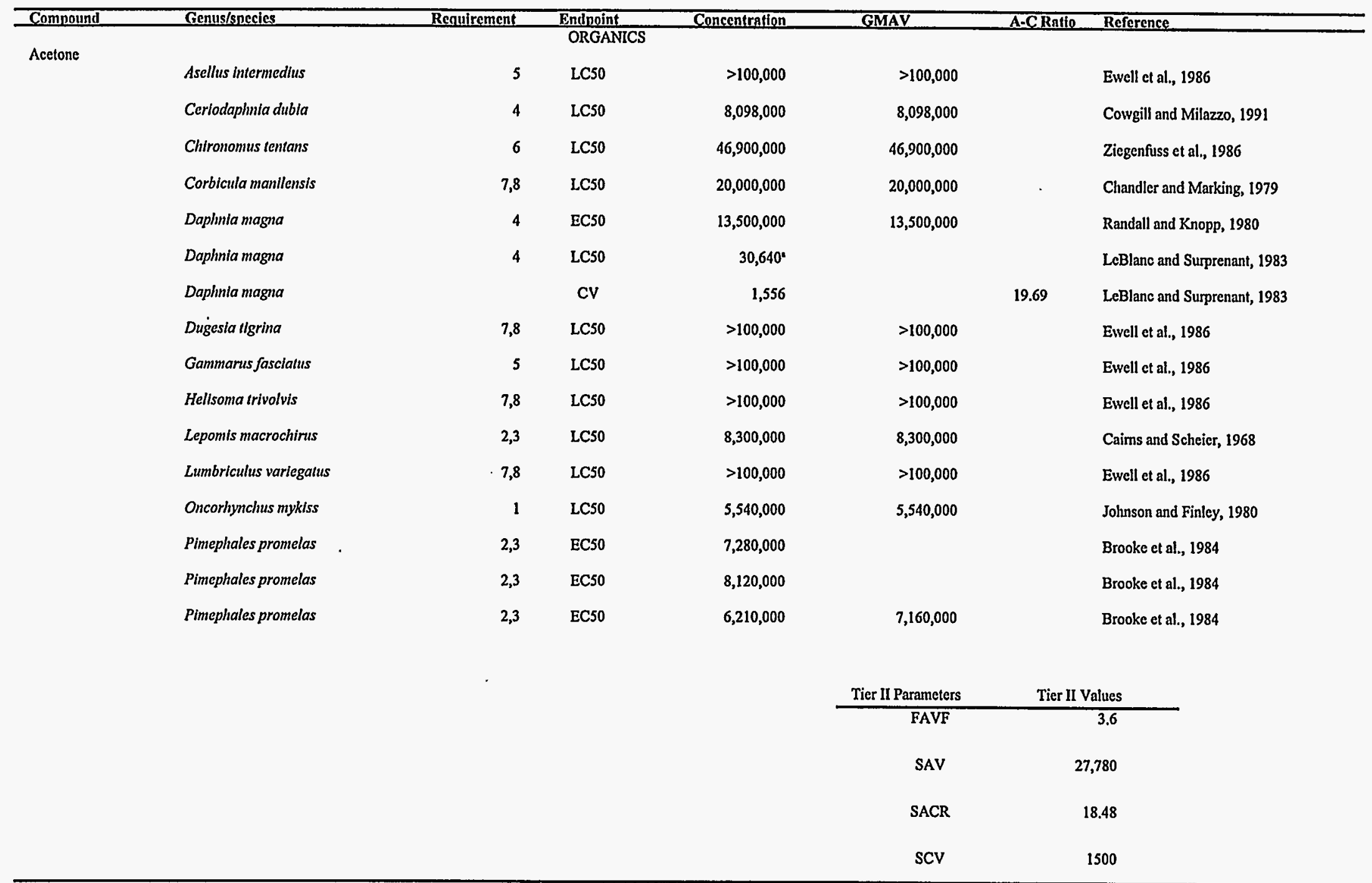


Table A.1. (continued)

\begin{tabular}{|c|c|c|c|c|c|c|}
\hline Compound & Genus/species & Requirement & Endpoint & Concentration & A-CRatio & Reference \\
\hline \multirow[t]{7}{*}{ Anthracene } & Daphnia magna & 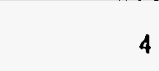 & EC50 & 95 & & Munoz and Tarazona, 1993 \\
\hline & Daphmia pulex & 4 & EC50 & 754 & 267.6 & Smith et al., 1988 \\
\hline & & & & & Tier II Parameters & Tier II Values \\
\hline & & & & - & FAVF & 20.5 \\
\hline & & & & & SAV & 13.06 \\
\hline & & & & & SACR & 17.9 \\
\hline & & & & & scV & 0.73 \\
\hline
\end{tabular}


Table A.1. (continued)

\begin{tabular}{|c|c|c|c|c|c|c|c|}
\hline $\begin{array}{l}\text { Compound } \\
\text { Benzene }\end{array}$ & Genus/snecies & Requirement & Endpoint & Concentration & GMAV & A-CRatio & Reference \\
\hline \multirow[t]{23}{*}{ Benzene } & Asellus aqualicus & 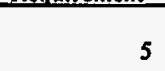 & LC50 & 254,000 & 254,000 & & Erben and Pisl, 1993 \\
\hline & Carassius auratus & 2,3 & LC50 & 34,420 & 34,420 & & Pickering and Henderson, 1966 \\
\hline & Chironomus thummi & 6 & LCso & 100,000 & 100,000 & & Sloff, 1983 \\
\hline & Coltus cognatus & 2,3 & LC50 & 13,500 & 13,500 & & Moles et al., 1979 \\
\hline & Daphnia magna & 4 & LC50 & 200,000 & & & LeBlanc, 1980 \\
\hline & Daphia magna & 4 & LC50 & 400,000 & & & Canton and Adema, 1978 \\
\hline & Daphla magna & 4 & LC50 & 620,000 & - & & Canton and Adema, 1978 \\
\hline & Daphnia magna & 4 & LC50 & 412,000 & & & Canton and Adema, 1978 \\
\hline & Daphmia magna & 4 & LC50 & 356,000 & & & Canton and Adema, 1978 \\
\hline & Daphmia magna & 4 & LC50 & 412,000 & & & Canton and Adema, 1978 \\
\hline & Daphia magna & 4 & LC50 & 356,000 & 376,200 & & Canton and Adema, 1978 \\
\hline & Daphnia pulex & 4 & LC50 & 345,000 & & & Canton and Adema, 1978 \\
\hline & Daphmla pulex & 4 & LC50 & 265,000 & 302,400 & & Canton and Adema, 1978 \\
\hline & Gasterosteus aculeatus & 2,3 & LC50 & 21,800 & 21,800 & & Moles et al., 1979 \\
\hline & Ictalurus punctatus & 2,3 & LC50 & 425,000 & 425,000 & & Johnson and Finley, 1980 \\
\hline & Lepomis macrochirus & 2,3 & LC50 & 22,490 & 22,490 & & Pickering and Henderson, 1966 \\
\hline & Oncorhynchus gorbuscha & 1 & LC50 & 4,630 & & & Moles et al., 1979 \\
\hline & Oncorhynchus kisutch & 1 & LC50 & 12,350 & & & Moles et al., 1979 \\
\hline & Oncorhynchus mykiss & 2,3 & LC50 & 5,300 & & & DeGraeve et al., 1982 \\
\hline & Oncorhynchus mykiss & 1 & LC50 & 21,600 & - & & Hodson et al,, 1984 \\
\hline & Oncorhynchus nerka & 1 & LC50 & 9,430 & & & Moles et al., 1979 \\
\hline & Oncorhynchus ishawylscha & 1 & LC50 & 10,280 & 9,008 & & Moles et al., 1979 \\
\hline & Pimephales promelas & 2,3 & LC50 & 24,600 & & & Geiger et al, 1990 \\
\hline
\end{tabular}


Table A.1. (continued)

\begin{tabular}{|c|c|c|c|c|c|c|}
\hline Compound & Genus/species & Requirement & Endpoint & Concentration & GMAV & Reference \\
\hline & Pimephales promelas & 2,3 & LC50 & 12,600 & 17,600 & Geiger et al, 1990 \\
\hline & Poecilia retlculata & 2,3 & LC50 & 36,600 & & Pickering and Henderson, 1966 \\
\hline & Poecilia reticulata & 2,3 & LC50 & 28,600 & 32,350 & Galassi et al., 1988 \\
\hline & Salvelinus malma & 2,3 & LC50 & 10,430 & & Moles et al., 1979 \\
\hline & Salvelinus malma & 2,3 & LC50 & 10,480 & 10,450 & Moles et al., 1979 \\
\hline & Thymallus arcticus & 2,3 & LCSO & 12,890 & 12,890 & Moles et al., 1979 \\
\hline & & & & & Tier II Parameters & Tier II Values \\
\hline & & & & & FAVF & 4.0 \\
\hline & & & & & SAV & 2,252 \\
\hline & & & & & scV & 130 \\
\hline
\end{tabular}


Table A.1. (continued)

\begin{tabular}{|c|c|c|c|c|c|c|c|c|}
\hline Compound & Genus/snecies & Requirement & Endnoint & Concentration & GMAV & A-CRntio & \multicolumn{2}{|l|}{ Reference } \\
\hline Benzidine & Daplimia magna & 4 & EC50 & 600 & 600 & & Kuhn et al., 1989 & \\
\hline & Oncorlynclus myklss & 1 & LC50 & 7,400 & $7,400^{2}$ & & EPA, 1980c & \\
\hline & Salmo trutta lacustris & 1 & LC50 & 4,350 & $4,350^{\circ}$ & & EPA, $1980 c$ & \\
\hline & Notropis Itutrensis & 2,3 & LC50 & 2,500 & $2,500^{\circ}$ & & EPA, 1980c & \\
\hline & & & & & Tier II & arameters & \multicolumn{2}{|l|}{ Tier II Values } \\
\hline & & & & & & FAVF & \multicolumn{2}{|l|}{8.6} \\
\hline & & & & & & SAV & 69.77 & • \\
\hline & & & & & & SACR & 17.9 & \\
\hline & & & & & & SCV & ' 3.9 & \\
\hline
\end{tabular}

- The EPA criteria document was cited because the data come from an EPA intemal investigation, which was not available. 
Table A.1. (continued)

\begin{tabular}{|c|c|c|c|c|c|c|}
\hline \multirow{2}{*}{$\begin{array}{l}\text { Compound } \\
\text { Benzo(a)anthracene }\end{array}$} & Genus/snecies & Requirement & Endooint & Concentration & A.CRatio & \multirow{2}{*}{$\begin{array}{l}\text { Reference } \\
\text { Trucco et al., } 1983\end{array}$} \\
\hline & Daplmia pulex & 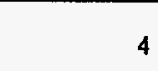 & LC50 MOR & $10^{\circ}$ & 10 & \\
\hline & & & & & Tier II Parameters & Tier II Values \\
\hline & & & & & FAVF & 20.5 \\
\hline & & & & & SAV & 0.4878 \\
\hline & & & & & SACR & 17.9 \\
\hline & & & & & SCV & 0.027 \\
\hline
\end{tabular}

- The test was based on a non-standard, but conservative, exposure of 96 hours. The standard exposure is $48 \mathrm{hr}$ for daphnids.

The length of the Daphnid is 1.9-2.1 mm; the age of the Daplnid species is not available. 
Table A.1. (continued)

\begin{tabular}{|c|c|c|c|c|c|c|}
\hline \multirow{2}{*}{$\frac{\text { Compound }}{\text { Benzo(a)pyrene }}$} & Genus/species & Requirement & Endpoint & Concentration & A=CRatio & Reference \\
\hline & Daphmia pulex & 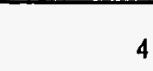 & LC50 MOR & 54 & 5 & Trucco et al., 1983 \\
\hline & & & & & Tier II Parameters & Tier II Valucs \\
\hline & & & & & FAVF & 20.5 \\
\hline & & & & & SAV & 0.2439 \\
\hline & & & & & SACR & 17.9 \\
\hline & & & & & SCV & 0.014 \\
\hline
\end{tabular}

'The test was based on a non-slandard, but conservative, exposure of 96 hours. The standard exposure is $48 \mathrm{lu}$ for daphnids.

The length of the Daphnid is $1.9-2.1 \mathrm{~mm}$; the age of the Daphnid species is not available. 
Table A.1. (continued)

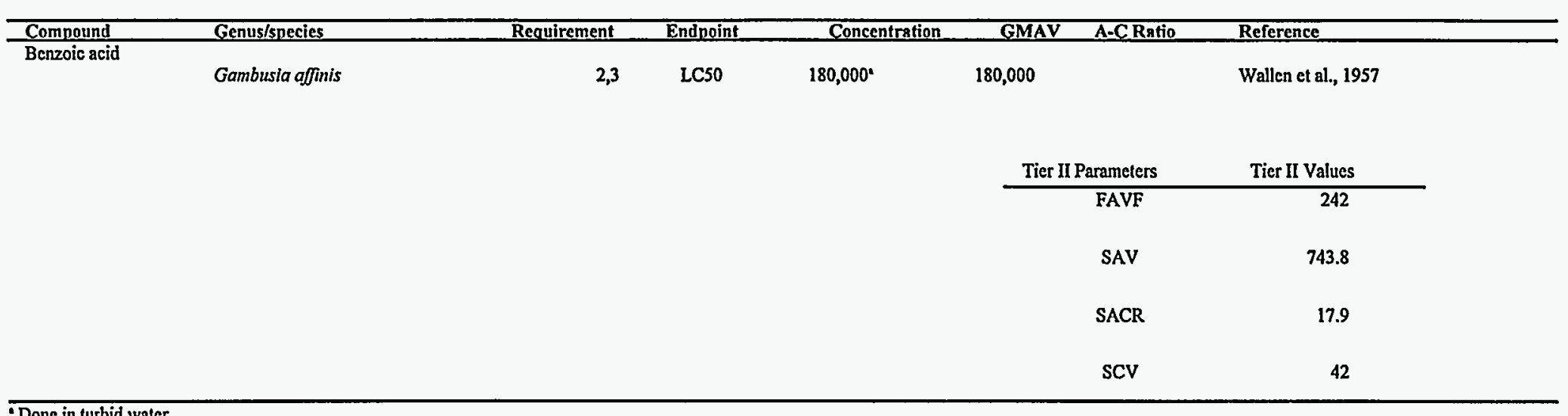

Done in turbid water. 
Table A.1. (continued)

\begin{tabular}{|c|c|c|c|c|c|c|}
\hline \multirow{8}{*}{$\begin{array}{l}\text { Compound } \\
\text { Benzyl alcohol }\end{array}$} & Genus/species & Requirement & Endnoint & Concentration. & GMAV & A-C.Ratio Reference \\
\hline & Lepomis macrochirus & 2,3 & LC50 & 10,000 & 10,000 & Dawson et al, 1977 \\
\hline & Pimephales promelas & 2,3 & LC50 & 460,000 & 460,000 & Mattson et al., 1976 \\
\hline & & & & & Tier If Parameters & Tier II Values \\
\hline & & & & & FAVF & 64.8 \\
\hline & & & & & SAV & 154.3 \\
\hline & & & & & SACR & 17.9 \\
\hline & & & & & SCV & 8.6 \\
\hline
\end{tabular}


Table A.1. (continued)

\begin{tabular}{|c|c|c|c|c|c|}
\hline Compound $\quad$ Genus/snecies & Requirement & Endpoint & Concentration & A-CRatio & Reference \\
\hline $\begin{array}{l}\text { BHC (other than Lindane) } \\
\text { Daphmia magna }\end{array}$ & \multirow[t]{5}{*}{ 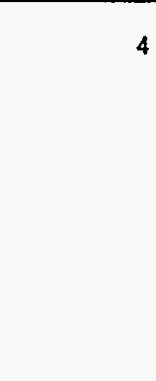 } & \multirow[t]{5}{*}{ EC50 } & \multirow[t]{5}{*}{800} & 800 & Canton et al., 1975 \\
\hline & & & & Ticr II Parameters & Tier II Values \\
\hline & & & & FAVF & 20.5 \\
\hline & & & & SAV & 39.02 \\
\hline & & & & SACR & 17.9 \\
\hline & & & & SCV & 2.2 \\
\hline
\end{tabular}


Table A.1. (continued)

\begin{tabular}{|c|c|c|c|c|c|c|c|}
\hline \multicolumn{2}{|c|}{$\begin{array}{l}\text { Compound } \\
\text { Bis(2-ethylhexyl) plithalate }\end{array}$} & Requirement & Endnoint & Concentration & GMAV & A-CRatio & Reference \\
\hline \multicolumn{8}{|c|}{$\begin{array}{l}\text { Bis(2-ethyllexyl) plithalater } \\
\text { Chironomus plumosus }\end{array}$} \\
\hline & Daphinla pulex & 4 & EC50 & 133 & 133 & & LeBlanc, 1980 \\
\hline & Daphinia magna & 4 & LC50 & $2,000^{\circ}$ & & & Adams \& Heidolph, 1985 \\
\hline & Daphnia magna & & $\mathrm{CV}$ & 912 & & 2.193 & Adams \& Heidolph, 1985 \\
\hline & Gammarus pseudolimnaeus & 4 & LC50 & $>32,000$ & & & Sanders et al., 1973 \\
\hline & Gasterosteus aculeatus & 2,3 & LCs0 & $>300$ & & & van den Dikkenberg et al., 1989 \\
\hline & Ictalurus punciatus & 2,3 & LC50 & $>100,000$ & & & Jolunson and Finley, 1980 \\
\hline & Jordanella floridae & 2,3 & LC50 & $>320$ & & & Adema et al., 1981 \\
\hline & Lepomis macrochirus & 2,3 & LC50 & $>770,000$ & & & Buccafusco et al., 1981 \\
\hline & Lepomis macrochints & 2,3 & LC50 & $>100,000$ & & & Johnson and Finley, 1980 \\
\hline & Oncorhynchus kisutch & 1 & LC50 & $>100,000$ & & & Johnson and Finley, 1980 \\
\hline & Oncorhynchus mykiss & 1 & LC50 & $>320$ & & & Adams et al., 1995 \\
\hline & Pimephales promelas & 2,3 & LC50 & $>670$ & & & Adams et al., 1995 \\
\hline & Pimephales promelas & 2,3 & LC50 & $>160$ & & & Adams ct al., 1995 \\
\hline & Rana pipiens & 3 & LC50 & 4,440 & 4,440 & & Birge et al., 1978 \\
\hline & & & & & Tier II & arameters & Tier II Values \\
\hline & & & & & & FAVF & 5.0 \\
\hline . & & & & & & SAV & 26.60 \\
\hline & & & & & & SACR & 8.890 \\
\hline & & & & & & SCV & 3.0 \\
\hline
\end{tabular}

- This LC50 was used to calculate the A-C ratio, but not the GMAV because an EC50 was available. 
Table A.1. (continued)

\begin{tabular}{|c|c|c|c|c|c|c|}
\hline \multirow{8}{*}{$\frac{\text { Compound }}{\text { 2-Butanone }}$} & Genus/species & Requirement & Endpoint & Concentration & GMAV & A-CRatio \\
\hline & Daphnia magna & 4 & EC50 & $5,091,000$ & $5,091,000$ & Randall and Knopp, 1980 \\
\hline & Pimcphales promelas & 2,3 & LC50 & $3,200,000$ & $3,200,000$ & Veith et al, 1983 \\
\hline & & & & & Tier II Parameters & Tier II Values \\
\hline & & & & & FAVF & 13.2 \\
\hline & & & & & SAV & 242,400 \\
\hline & & & & & SACR & 17.9 \\
\hline & & & & & scv & 14,000 \\
\hline
\end{tabular}


A-32

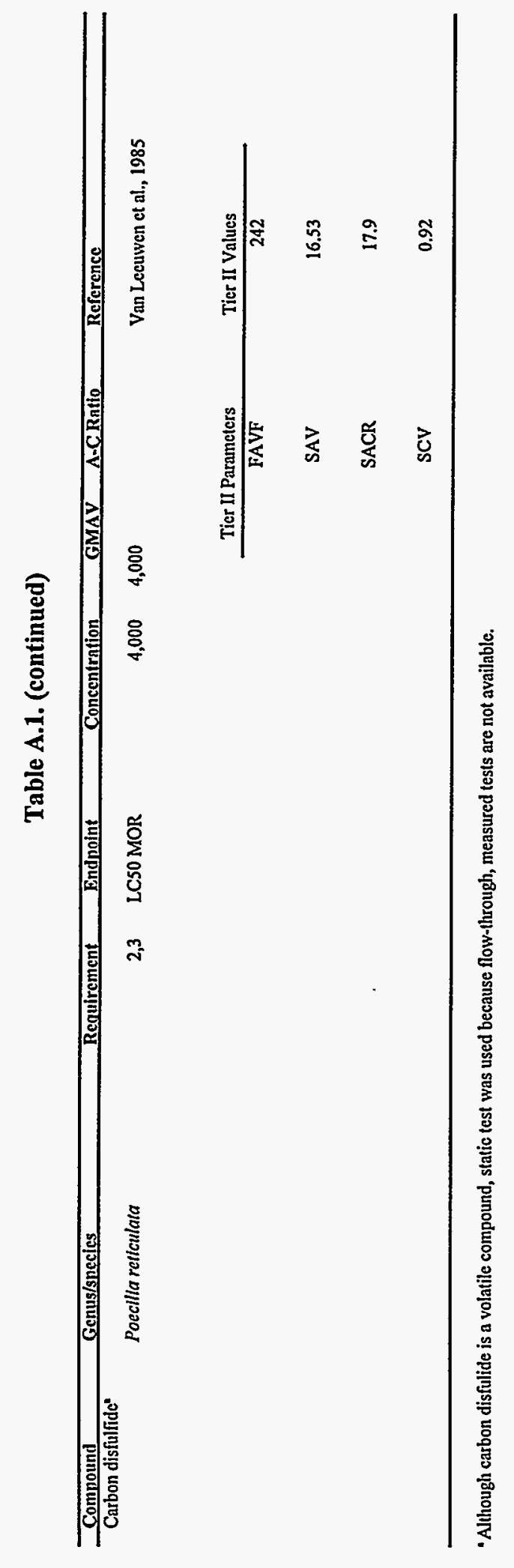


Table A.1. (continued)

\begin{tabular}{|c|c|c|c|c|c|c|}
\hline \multirow{9}{*}{$\begin{array}{l}\text { Compound } \\
\text { Carbon tetrachloride" }\end{array}$} & Genus/species & Requirement & Endpoint & Concentration & A-CRati & Reference \\
\hline & Pimcphales promelas & 2,3 & LC5O & 41,400 & & Geiger et al., 1990 \\
\hline & Pimcphales promelas & 2,3 & LC50 & 43,300 & & Kimball, n.d. \\
\hline & Pimephales promelas & 2,3 & LC50 & 42,900 & 42,530 & Kimball, n.d. \\
\hline & & & & & Tier II Parameters & Tier II Values \\
\hline & & & & & FAVF & 242 \\
\hline & & & & & SAV & 175.7 \\
\hline & & & & & SACR & 17.9 \\
\hline & & & & & SCV & 9.8 \\
\hline
\end{tabular}

- Because carbon tetracliloride is a volatile compound, only flow-through, measured tests were used. 
Table A.1. (continued)

\begin{tabular}{|c|c|c|c|c|c|c|}
\hline Compound & Genus/species & Requirement & Endpoint & Concentration & A-C ratio & Reference \\
\hline \multicolumn{7}{|c|}{ Chlorobenzenc } \\
\hline & Carassius auratus & 2,3 & LC50 & 51,620 & 51,620 & Pickering and Henderson, 1966 \\
\hline & Cerlodaphimia dubia & 4 & LC50 & $7,900^{\circ}$ & & Cowgill ct al., 1985 \\
\hline & Ceriodaplmia dubia & 4 & LC50 & $7,900^{\circ}$ & & Cowgill et al., 1985 \\
\hline & Ceriodaphimia dubia & 4 & LC50 & $11,400^{\circ}$ & 8,927 & Cowgill et al., 1985 \\
\hline & Daphmia magna & 4 & LC50 & 86,000 & & LcBlanc, 1980 \\
\hline & Daphnia magna & 4 & LC50 & $13,000^{\circ}$ & & Cowgill et al., 1985 \\
\hline & Daphlia magna & 4 & LC50 & $10,700^{\circ}$ & & Cowgill et al., 1985 \\
\hline & Daphlia magna & 4 & LC50 & $15,400^{\circ}$ & 116,500 & Cowgill ct al., 1985 \\
\hline & Lepomis macrochirus & 2,3 & LC50 & 7,400 & 7,400 & Bailey et al., 1985 \\
\hline & Oncorhynchus mykiss & 1 & LC50 & 7,460 & 7,460 & Hodson et al., 1984 \\
\hline & PImephales promelas & 2,3 & LC50 & 16,900 & 16,900 & Geiger et al., 1990 \\
\hline & Poccilla reticulata & 2,3 & LC50 & 45,530 & 45,530 & Pickering and Henderson, 1966 \\
\hline & & & & & Tier II Parameters & Tier II Values \\
\hline & . & & & & FAVF & 6.5 \\
\hline & & & & & SAV & 1,138 \\
\hline & & & & & SACR & 17.9 \\
\hline & & & & & SCV & 64 \\
\hline
\end{tabular}

- Author indicated both $D$. magna and C. dubia/affinis are less sensitive to chlorobenzene at $24^{\circ} \mathrm{C}$ than at $20^{\circ} \mathrm{C}$; thus, tests with $20^{\circ} \mathrm{C}$ were used to established a conservative estimate of the effect of chlorobenzene. 
Table A.1. (continued)

\begin{tabular}{|c|c|c|c|c|c|c|}
\hline \multirow{21}{*}{ Chloroform" } & Genus/species & Requirement & Endnoint & Concentration & GMAV A.CRatio & Reference \\
\hline & Ictalurus punctatus & 2,3 & LC50 & 75,000 & 75,000 & Anderson and Lusty, 1980 \\
\hline & Lepomis macrochinus & 2,3 & LC50 & 16,200 & & Anderson and Lusty, 1980 \\
\hline & Lepomis macrochirus & 2,3 & LC50 & 22,300 & & Anderson and Lusty, 1980 \\
\hline & Lepomis macrochirus & 2,3 & LC50 & 13,300 & & Anderson and Lusty, 1980 \\
\hline & Lepomis macrochirus & 2,3 & LC50 & 18,300 & & Anderson and Lusty, 1980 \\
\hline & Lepomis macrochinus & 2,3 & LC50 & 20,800 & 17,880 & Anderson and Lusty, 1980 \\
\hline & Microplerus salmoides & 2,3 & LC50 & 55,800 & & Anderson and Lusty, 1980 \\
\hline & Micropterus salmoides & 2,3 & LC50 & 52,500 & & Anderson and Lusty, 1980 \\
\hline & Microptenus salmoides & 2,3 & LC50 & 45,400 & 51,040 & Anderson and Lusty, 1980 \\
\hline & Oncorhynchus mykiss & 1 & LC50 & 18,200 & & Anderson and Lusty, 1980 \\
\hline & Oncorhynchus mykiss & 1 & LCso & 18,400 & & Anderson and Lusty, 1980 \\
\hline & Oncorhynchus mykiss & 1 & LC50 & 22,100 & & Anderson and Lusty, 1980 \\
\hline & Oncorhynchus myklss & 1 & LC50 & 15,100 & & Anderson and Lusty, 1980 \\
\hline & Oncorhynchus mykiss & 1 & LC50 & 17,100 & 18,040 & Anderson and Lusty, 1980 \\
\hline & PImephales promelas & 2,3 & EC50 & 70,700 & 70,700 & Geiger et al., 1990 \\
\hline & & & & & Tier II Parameters & Tier II Values \\
\hline & & & & & FAVF & 36.2 \\
\hline & & & & & SAV & 493.9 \\
\hline & & & & & SACR & 17.9 \\
\hline & & & & & SCV & 28 \\
\hline
\end{tabular}

- Because chloroform is a volatile compound, only flow-through, measured tests were used. 
Table A.1. (continued)

\begin{tabular}{|c|c|c|c|c|c|c|}
\hline Compound & Genus/snecies & Regulfement & Endnoint & Concentration & GMAV A-CRalio & Reference \\
\hline \multirow[t]{25}{*}{ p,p'DDD } & Asellus brevicaudus & 5 & LC50 & 10 & & Sanders, 1972 \\
\hline & Asellus brevicaudus & 5 & LCs0 & 16 & 12.65 & Mayer and Ellersicck, 1986 \\
\hline & Bufo woodhousel & 3 & LC50 & 140 & 140 & Sanders, 1970 \\
\hline & Cypridopsis vidua & 5 & EC50 & 45 & 45 & Mayer and Ellersieck, 1986 \\
\hline & Daphmla pulex & 4 & EC50 & 3.2 & 3.2 & Mayer and Ellersicck, 1986 \\
\hline & Gammarus fasciatus & 5 & LC50 & 0.6 & & Sanders, 1972 \\
\hline & Gammarus fasciatus & 5 & LC50 & 0.86 & & Sanders, 1972 \\
\hline & Gammarus lacusirls & 5 & LC50 & 0.64 & 0.68 & Sanders, 1969 \\
\hline & Ictalurus punctatus & 2,3 & LC50 & 1,500 & 15,000 & Mayer and Ellersieck, 1986 \\
\hline & Ischnura verilcalis & 6 & LC50 & 34 & 34 & Mayer and Ellersieck, 1986 \\
\hline & Micropterus salmoides & 2,3 & LC50 & 42 & 42 & Mayer and Ellersieck, 1986 \\
\hline & Oncorhynchus mykiss & 1 & LC50 & 70 & 72 & Mayer and Ellersieck, 1986 \\
\hline & Palaemoneles kadiakensis & 5 & LC50 & 0.68 & & Sanders, 1972 \\
\hline & Palaemonetes kadiakensis & 5 & LC50 & 2.4 & 1.3 & Mayer and Ellersieck, 1986 \\
\hline & Pimephales promelas & 2,3 & LC50 & 4,400 & 4,400 & Mayer and Ellersieck, 1986 \\
\hline & Polycelis felina & 7,8 & LC50 & 740 & 740 & Kouyoumjian and Uglow, 1974 \\
\hline & Pseudacris iriseriata & 3 & LC50 & 400 & 400 & Sanders, 1970 \\
\hline & Pteronarcys califomica & 6 & LCso & 380 & 380 & Sanders and Cope, 1968 \\
\hline & Simocephalus serrulatus & 4 & EC50 & 4.5 & 4.5 & Mayer and Ellersieck, 1986 \\
\hline & Stizostedion vitreum & 2,3 & LC50 & 14 & 14 & Mayer and Ellersieck, 1986 \\
\hline & & & & & Tier II Parameters & Tier II Values \\
\hline & & & & & FAVF & 3.6 \\
\hline & & & & & SAV & 0.1889 \\
\hline & & & & & SACR & 17.9 \\
\hline & & & & & SCV & 0.011 \\
\hline
\end{tabular}




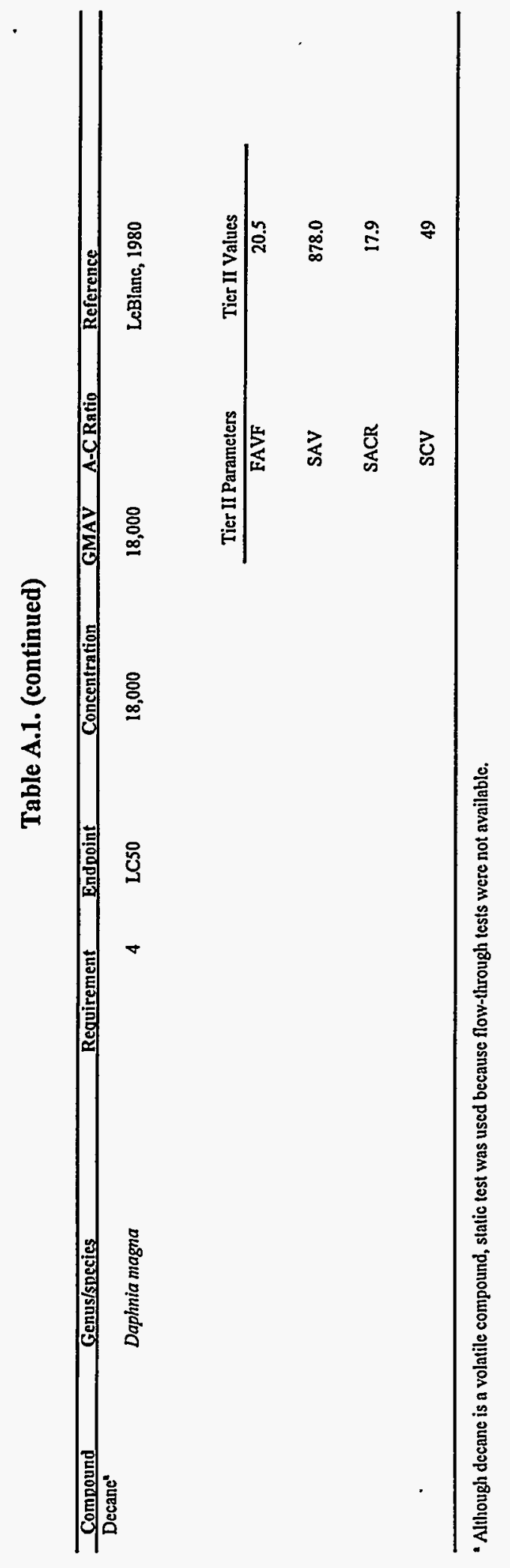


Table A.1. (continued)

\begin{tabular}{|c|c|c|c|c|c|c|c|}
\hline Compound & Genus/species & Requirement & Endpoint & Concentration & GMAV & $\overline{A-C}$ ratio & Reference \\
\hline \multicolumn{8}{|c|}{ Di-n-butyl phthalatc } \\
\hline & Chironomus plumosus & 6 & EC50 & 760 & 760 & & Streufert et al., 1980 \\
\hline & Daphnia magna & 4 & EC50 & 5200 & 5200 & & McCarthy and Whitmore, 1985 \\
\hline & Daphinia magna & & CV & 1004 & & 5.179 & McCarthy and Whitmore, 1985 \\
\hline & Gammartis pseudolimnaeus & 5 & LC50 & 2100 & 2100 & & Jolunson and Finlcy, 1980 \\
\hline & Ictalurus punctatus & 2,3 & LC50 & 2900 & 2900 & & Johnson and Finley, 1980 \\
\hline & Lepomis macrochiris & 2,3 & LC50 & 1200 & & & Buccafusco et al., 1981 \\
\hline & Lepomis macrochirus & 2,3 & LC50 & 700 & 916.5 & & Jolinson and Finlcy, 1980 \\
\hline & Oncorlnynchus mykiss & 1 & LC50 & 1600 & 1600 & & Adams et al,, 1995 \\
\hline & Oncorhynchus mykiss & & $\mathrm{CV}$ & $137.8^{4}$ & & 11.61 & Rodes et al., 1995 \\
\hline & Orconectes nais & 5 & LC50 & $10000^{b}$ & 10000 & & Johnson and Finley, 1980 \\
\hline & Pimephales promelas & 2,3 & LC50 & 1100 & & & Geiger et al., 1985 \\
\hline & Pimephales promelas & 2,3 & LC50 & 850 & & & Geiger et al., 1985 \\
\hline & Pimephales promelas & 2,3 & LC50 & $2020^{\mathrm{sd}}$ & & & McCarthy and Whitmore, 1985 \\
\hline & Pimephales promelas & 2,3 & LC50 & 920 & 1148 & & Adams et al., 1995 \\
\hline & Pimtephales promelas & & $\mathrm{CV}$ & 748.3 & & 2.699 & McCarthy and Whitmore, 1985 \\
\hline & & & & & Tier II 1 & rameters & Tier II Values \\
\hline & & & & & & FAVF & 4.0 \\
\hline & & & & & & SAV & 190.0 \\
\hline & & & & & & SACR & 5.455 \\
\hline & & & & & & SCV & 35 \\
\hline
\end{tabular}

- Length of the test is $60 \mathrm{~d}$ post-hatch ( $99 \mathrm{~d}$ exposure); the National Guidelines recommend $90 \mathrm{~d}$ post-hatch for salmonids. 
Table A.1. (continued)

'Authors note toxicity is hardness(44-272 ppm) and $\mathrm{pH}(6.5-9.0)$ independent; no further data are available

Derived from range-finding test.

- ACR derived from acute test of larval fathead minnows is the only test available as part of the same study as the chronic test. The National Guidelines

recommend using juvenile fish for deriving $A C R$.

- Because of an accident during the experiment, length of the test is $20 \mathrm{~d}$ post-hatch; the National Guidelines recommend $28-32 \mathrm{~d}$ post-hatch for fish other than salmonids.

fish died at $1.0 \mathrm{mg} / \mathrm{L}$, "no evidence that additional exposure time would have produced any meaningful result". 
Table A.1. (continued)

\begin{tabular}{|c|c|c|c|c|c|c|}
\hline \multirow{9}{*}{ Compound } & Genus/species & Requirement & Endlpoint & Concentration & A-CRatio & Reference \\
\hline & Daplmia magna & 4 & LC50 & 1,700 & 1,700 & LeBlanc, 1980 \\
\hline & Pimephales promelas & 2,3 & EC50 & 780 & & Geiger ct al., 1988 \\
\hline & Pimcphales promelas & 2,3 & EC50 & 980 & 874.3 & Geiger et al., 1988 \\
\hline & & & & & Tier II Parameters & Tier II Values \\
\hline & & & & & FAVF & 13.2 \\
\hline & & & & & SAV & 66.23 \\
\hline & & & & & SACR & 17.9 \\
\hline & & & & & SCV & 3.7 \\
\hline
\end{tabular}


Table A.1. (continued)

\begin{tabular}{|c|c|c|c|c|c|c|}
\hline \multirow{2}{*}{$\begin{array}{l}\text { Compound } \\
\text { 1,1-Dichlorocthane }\end{array}$} & Genus/species & Requirement & Endpoint & Concentration & A-C.CRatio & Reference \\
\hline & Poccilia reticulala & 2,3 & LC50 & 202,000 & 202,000 & Koneman, 1981 \\
\hline & & & & & Tier II Parameters & Tier II Values \\
\hline & & & & & FAVF & 242 \\
\hline & & & & & SAV & 834.7 \\
\hline & & & & & SACR & 17.9 \\
\hline & & & & & scV & 47 \\
\hline
\end{tabular}

- Although 1,1-dichloroethane is a volatile compound, static test was used because flow-llough test is not available. 
Table A.1. (continued)

\begin{tabular}{|c|c|c|c|c|c|c|c|}
\hline Compound & Genus/species & Requirement & Endpoint & Concentration & GMAV & A-C ratio & Reference \\
\hline & \multicolumn{6}{|c|}{ 1,2-Dichloroethance } & Richter ct al., 1983 \\
\hline & PImephales promelas & 2,3 & LC50 & 116,000 & 116,000 & & Walbridge et al,, 1983 \\
\hline & PImephales promelas & & $\mathrm{cV}$ & 41,360 & & 2.804 & Benoit ct al, 1985 \\
\hline & & & & & Tier II & arameters & Tier II Values \\
\hline & & & & & & FAVF & 13.2 \\
\hline & & & & & & SAV & 8,788 \\
\hline & & & & & & SACR & 9.649 \\
\hline & & & & & - & SCV & 910 \\
\hline
\end{tabular}

- Because 1,2-Dichloroethane is a volatile compound, only flow-through, measured tests were used (static, measured tests for Daphnids). 
Table A.1. (continued)

\begin{tabular}{|c|c|c|c|c|c|c|c|}
\hline Compound & Genus/species & Requirement & Endpoint & Concentration & GMAV & A.C Ratio & Reference \\
\hline & Pimephales promelas & 2,3 & LC50MOR & 108,000 & 108,000 & , & Dill et al., 1980 \\
\hline & & & & & Tier Il & arameters & Tier II Values \\
\hline & & & & & & FAVF & 242 \\
\hline & & & & & & SAV & 446.3 \\
\hline & & & & & & SACR & 17.9 \\
\hline & & & & & & scV & 25 \\
\hline
\end{tabular}

-Although 1,1-dichloroethene is a volatile compound, static test is used because flow-through, measured tests are not available. 
Table A.1. (continued)

\begin{tabular}{|c|c|c|c|c|c|c|c|}
\hline \multirow{8}{*}{$\begin{array}{l}\text { Compound } \\
\text { 1,2-Dichloroethene' }\end{array}$} & Genus/species & Reguirement & Endnoint & Concentration & GMAV & $\overline{A-C \text { Ratio }}$ & Reference \\
\hline & Lepomis macroclitrus & 2,3 & LC50 & 140,000 & 140,000 & & Buccafusco, 1981 \\
\hline & Daphmia magna & 4 & LC50 & 220,000 & 220,000 & & LcBlanc, 1980 \\
\hline & & & & & Tier I & Parameters & Tier II Values \\
\hline & & & & & & FAVF & 13.2 \\
\hline & & & & & & SAV & 10,610 \\
\hline & & & & & & SACR & 17.9 \\
\hline & & & & & & SCV & 590 \\
\hline
\end{tabular}

- Although 1,2-dichlorocthene is a volatile compound, static tests were used because flow-through, measured tests are not available. 
Table A.1. (continued)

\begin{tabular}{|c|c|c|c|c|c|c|}
\hline \multirow{7}{*}{$\begin{array}{l}\text { Compound } \\
\text { 1,3-Dichloropropene }\end{array}$} & Genus/species & Requirement & Endnoint & Concentration & A-C.Ratio & Reference \\
\hline & Pimephales promelas & 2,3 & EC50 & 239 & 239 & Geiger et al., 1990 \\
\hline & & & & & Tier II Parameters & Tier II Values \\
\hline & & & & & FAVF & 242 \\
\hline & & & & & SAV & 0.9876 \\
\hline & & & & & SACR & 17.9 \\
\hline & & & & & SCV & 0.055 \\
\hline
\end{tabular}


Table A.1. (continued)

\begin{tabular}{|c|c|c|c|c|c|c|c|c|}
\hline \multirow{4}{*}{$\frac{\text { Compound }}{\text { Dictlyyl phithalate }}$} & Genus/species & Reguirement & Fndnoint & Concentration & GMAV & A.CRatio & \multicolumn{2}{|l|}{ Reference } \\
\hline & Daphmla magna & 4 & EC50 & 86,000 & 86,000 & \multirow{3}{*}{2.239} & \multicolumn{2}{|l|}{ Adams ct al., 1995} \\
\hline & Daphmla magna & & CV & 38,410 & & & \multicolumn{2}{|l|}{ Rlodes et al., 1995} \\
\hline & Leponis macrochirus & 2,3 & LC50 & 16,700 & 16,700 & & \multicolumn{2}{|l|}{ Adams ct al., 1995} \\
\hline \multirow[t]{3}{*}{ - } & Pimephales promelas & 2,3 & LC50 & 31,800 & & & Geiger et al., 1985 & - \\
\hline & Pimephales promelas & 2,3 & LC50 & 17,000 & \multicolumn{2}{|l|}{23,250} & \multicolumn{2}{|l|}{ Adams ct al., 1995} \\
\hline & Oncorhynchus mykiss & 1 & LC50 & 12,000 & 12,000 & & \multicolumn{2}{|l|}{ Adams ct al., 1995} \\
\hline & & & & & \multicolumn{2}{|c|}{ Tier II Parameters } & \multicolumn{2}{|l|}{ Tier II Values } \\
\hline & & & & & \multicolumn{2}{|c|}{ FAVF } & 6.5 & \\
\hline & - & & & & \multicolumn{2}{|r|}{ SAV } & 1,846 & \\
\hline & & & & & \multicolumn{2}{|r|}{ SACR } & 8.952 & \\
\hline & & & & & \multicolumn{2}{|r|}{ SCV } & 210 & \\
\hline
\end{tabular}




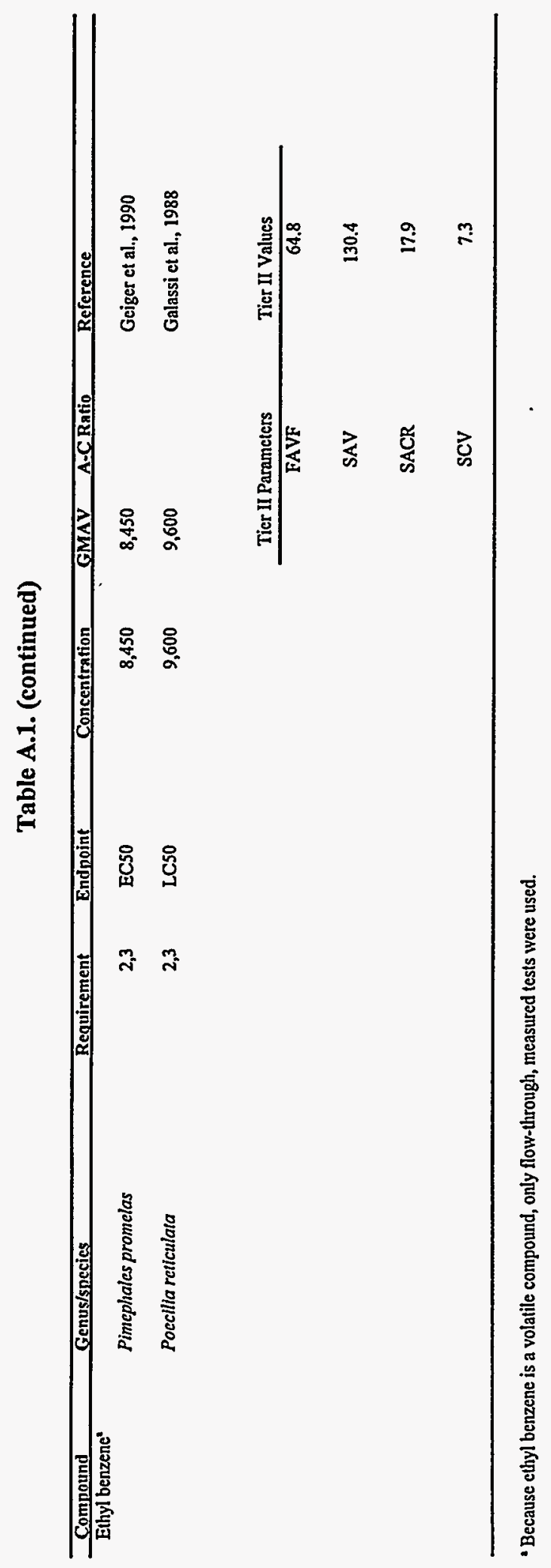


Table A.1. (continued)

\begin{tabular}{|c|c|c|c|c|c|c|}
\hline Compound & Genus/snecics & Requirement & Endnoint & Concentration & GMAV A-CRntio & Reference \\
\hline \multirow[t]{6}{*}{ Hexane } & Pimcphales promelas & 2,3 & EC50 & 2,500 & 2,500 & Geigcr et al., 1990 \\
\hline & & & & & Tier II Parameters & Tier II Valucs \\
\hline & & & & & FAVF & 242 \\
\hline & & & & & SAV & 10.33 \\
\hline & & & & & SACR & 17.9 \\
\hline & & & & & SCV & 0.58 \\
\hline
\end{tabular}


Table A.1. (continued)

\begin{tabular}{|c|c|c|c|c|c|c|c|}
\hline \multirow{7}{*}{$\frac{\text { Comnound }}{2 \text {-Hexanone }}$} & Genus/species & Requirement & Endpoint & Concentration & GMAV & A-CRatio & Reference \\
\hline & Pimephales promelas & 2,3 & LC50 & 428,000 & 428,000 & & Geiger et al., 1986 \\
\hline & & & & & Tier I & arameters & Tier II Values \\
\hline & & & & & & FAVF & 242 \\
\hline & & & & & & SAV & 1,769 \\
\hline & & & & & & SACR & 17.9 \\
\hline & & & & & & SCV & 99 \\
\hline
\end{tabular}


Table A.1. (continued)

\begin{tabular}{|c|c|c|c|c|c|c|}
\hline \multirow{2}{*}{$\begin{array}{l}\text { Comnound } \\
\text { 1-Methylnaphithalene }\end{array}$} & Genus/snecics & Requirement & Endnoint & Concentration & A-CRntio & Reference \\
\hline & Plmephales promelas & 2,3 & EC50 & 9,000 & 9,000 & Mattson ct al, 1976 \\
\hline & & & & & Tier II Parametcrs & Tier II Values \\
\hline & & & & & FAVF & 242 \\
\hline & & & & & SAV & 37.19 \\
\hline & & & & & SACR & 17.9 \\
\hline & & & & & SCV & 2.1 \\
\hline
\end{tabular}


Table A.1. (continued)

\begin{tabular}{|c|c|c|c|c|c|c|c|}
\hline \multirow{9}{*}{$\begin{array}{l}\text { Compound } \\
\text { 4-Methyl-2-pentanone }\end{array}$} & Genus/species & Requirement & Endpoint & Concentration & GMAV & $\overline{\text { A-CRatio }}$ & Reference \\
\hline & Pimephales promelas & 2,3 & LC50 & 540,000 & & & Brooke et al., 1984 \\
\hline & Pimcphales promelas & 2,3 & LC50 & 505,000 & 522,200 & & Veith et al., 1983a \\
\hline & Pimephales promelas & & $\mathrm{CV}$ & 77,360 & & 6.750 & Call et al., 1985 \\
\hline & & & & & Ticr II & aramcters & Tier II Values \\
\hline & & & & & & FAVF & 242 \\
\hline & & & & & & SAV & 2,158 \\
\hline & & & & & & SACR & 12.93 \\
\hline & & & & & & ScV & 170 \\
\hline
\end{tabular}


Table A.1. (continued)

\begin{tabular}{|c|c|c|c|c|c|c|}
\hline \multirow{12}{*}{ 2-Methylphenol } & Genus/species & Requirement & Endpoint & Concentration & A.CRntio & Reference \\
\hline & Carassius auratus & 2,3 & LC50 MOR & 23,250 & 23,250 . & Pickering and Henderson, 1966 \\
\hline & Leponis macrochirus & 2,3 & LC50 MOR & 20,780 & 20,780 & Pickering and Henderson, 1966 \\
\hline & Oncorhynchus mykiss & 1 & LC50 MOR & 8,400 & 8,400 & DeGraeve et al., 1980 \\
\hline & Pimephales promelas & 2,3 & LC50 & 14,000 & & Geiger et al., 1990 \\
\hline & Pimephales promelas & 2,3 & LC50 & 18,200 & 15,960 & DeGraeve ct al., 1980 \\
\hline & Poecilla rellculata & 2,3 & LC50 & 18,850 & 18,850 & Pickering and Henderson, 1966 \\
\hline & & & & & Tier II Parameters & Tier II Values \\
\hline & & & & & FAVF & 36.2 \\
\hline & & & & & SAV & 232.0 \\
\hline & & & & & SACR & 17.9 \\
\hline & & & & & SCV & 13 \\
\hline
\end{tabular}


Table A.1. (continued)

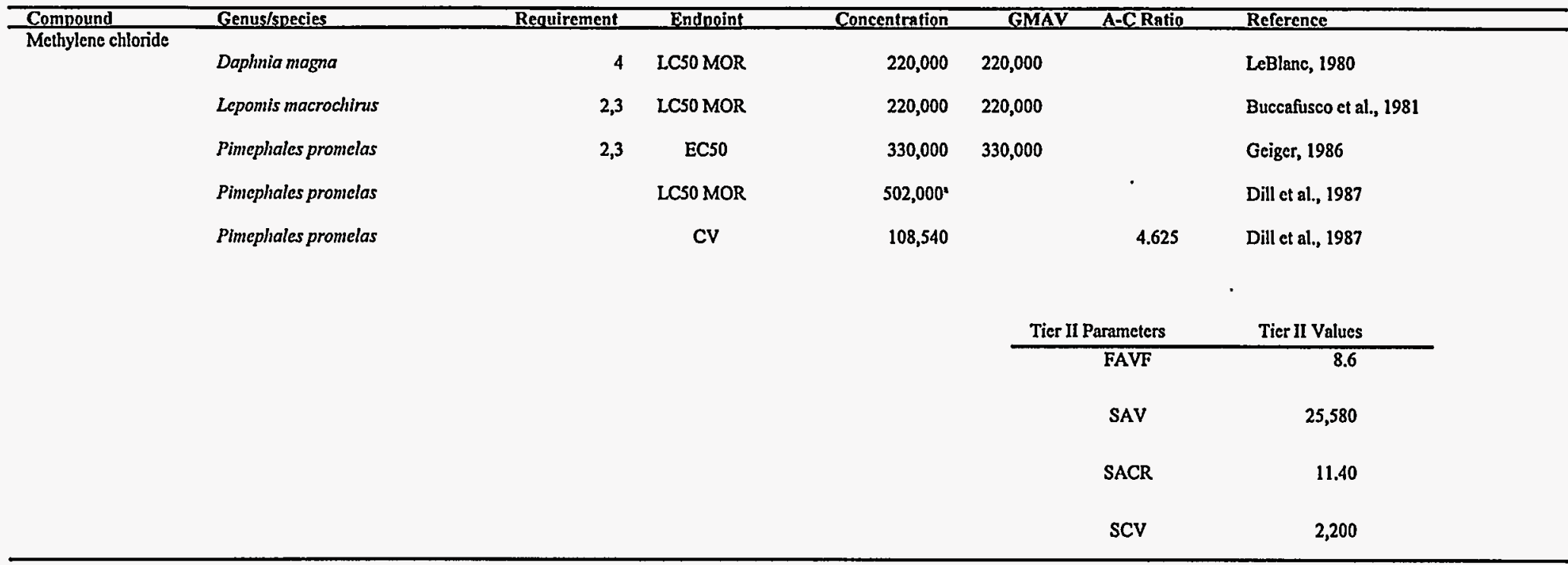

- The LC50 value is used to calculate the ACR because it is part of the same study as the chronic test; but it is not used to detemine the GMAV of Pimephales sp. because an EC50 is available. 
Table A.1. (continued)

\begin{tabular}{|c|c|c|c|c|c|c|c|}
\hline Compound & Genus/species & Requirement & Endpoint & Concentration & GMAV & $A-C$ ratio & Reference \\
\hline \multicolumn{8}{|l|}{ Napthalene } \\
\hline & Daplmia magna & 4 & EC50 & 2,194 & & & Munoz and Tarazona, 1993 \\
\hline & Daphinia pulex & 4 & EC50 & 4,663 & 3,199 & & Smill et al., 1988 \\
\hline & Oncorhynchus mykiss & 1 & LC50 & 1,600 & 1,600 & & DeGraeve et al., 1982 \\
\hline & Pimephales promelas & 2,3 & LC50 & 6,140 & & & Geiger et al., 1985 \\
\hline & PImephales promelas & 2,3 & LC50 & 7,900 & 6,965 & & DeGraeve et al., 1982 \\
\hline & Pimephales promelas & & $\mathrm{CV}$ & 619 & & 12.77 & DeGracve et al., 1982 \\
\hline & & & & & Tier II & arameters & Tier II Values \\
\hline & & & & & & FAVF & 8.6 \\
\hline & & & & & & SAV & 186.0 \\
\hline & & & & & & SACR & 15.96 \\
\hline & & & & & & SCV & 12 \\
\hline
\end{tabular}


Table A.1. (continued)

\begin{tabular}{|c|c|c|c|c|c|c|c|}
\hline \multirow{20}{*}{$\frac{\text { Compound }}{\text { 4-Nitrophenol }}$} & Genus/species & Requirement & Endpoint & Concentration & GMAV & A-CRatio & Reference \\
\hline & Daphia magna & 4 & EC50 & 7,680 & & & Keen and Baillod, 1985 \\
\hline & Daplmia magna & 4 & ECSO & 4,700 & 6,008 & & Kuhn et al., 1989 \\
\hline & Daphinia magna & & $\mathrm{cv}$ & 7,071 & & $2^{4}$ & Kulun et al., 1989 \\
\hline & Ganmmarus pseudolimnaeus & 5 & LC50 & 6,550 & 6,550 & & Howe et al., 1994 \\
\hline & Ictalturus punctatus & 2,3 & LCSO & 15,000 & 15,000 & & Holcombe et al., 1984 \\
\hline & Lepomis macrochirus & 2,3 & LC50 & 8,300 & 8,300 & & Buccafusco et al., 1981 \\
\hline & Oncorhynchus mykiss & 1 & LCso & 7,900 & 7,900 & & Hodson et al., 1984 \\
\hline & Oncorhynchus mykiss & & $\mathrm{CV}$ & 989.1 & & 7.987 & Hodson et al., 1991 \\
\hline & Pimephales promelas & 2,3 & LC50 & 59,000 & & & Phipps ct al., 1981 \\
\hline & PImephales promelas & 2,3 & LC50 & 62,000 & & & Phipps et al., 1981 \\
\hline & Pimephales promelas & 2,3 & LC50 & 41,000 & & & Holcombe ct al., 1984 \\
\hline & Pimephales promelas & 2,3 & LCso & 37,300 & & & Geiger et al., 1985 \\
\hline & Pimephales promelas & 2,3 & LCso & 41,000 & & & Geiger ct al., 1985 \\
\hline & Plmephales promelas & 2,3 & LC50 & 58,600 & 48,760 & & Geiger et al., 1985 \\
\hline & & & & & Tier II I & arameters & Tier II Values \\
\hline & & & & & & FAVF & 5.0 \\
\hline & & & & & & SAV & 1,202 \\
\hline & & & & & & SACR & 3.997 \\
\hline & & & & & & SCV & 300 \\
\hline
\end{tabular}

- Since the experimental A.C Ratio was less than 2, the A-C Ratio of D. magna is set to 2 (Stephan et al, 1985). 
A-56

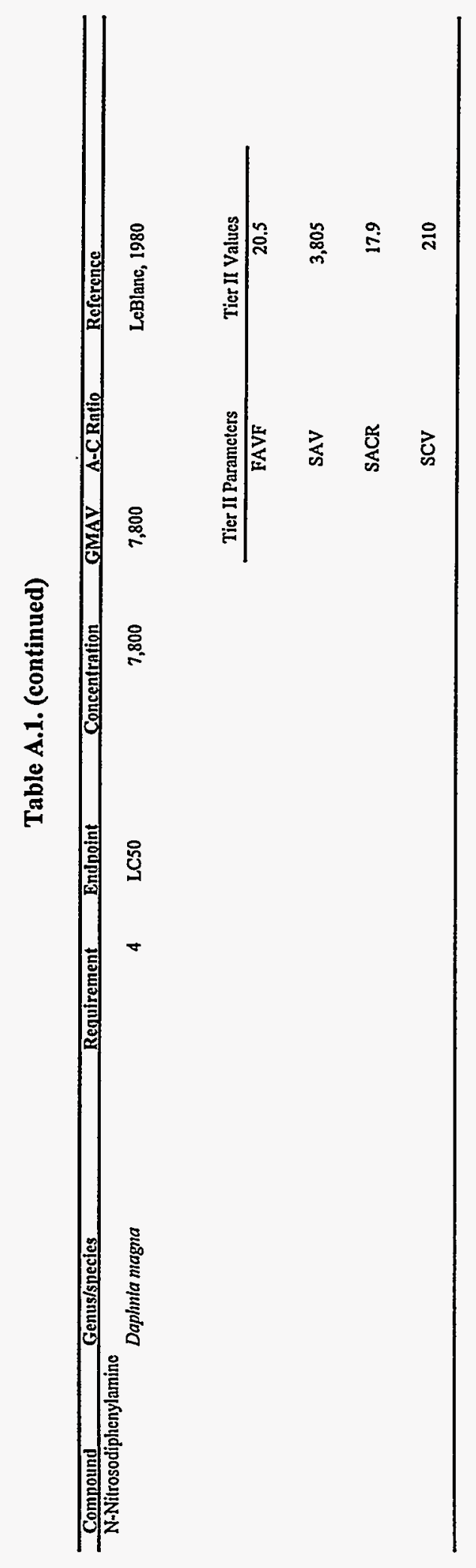


Table A.1. (continued)

\begin{tabular}{|c|c|c|c|c|c|c|}
\hline \multirow{7}{*}{$\frac{\text { Compound }}{\text { 2-Octanone }}$} & Genus/species & Requirement & Endnoint & Concentration & A-C.Ratio & Reference \\
\hline & Pimephales promelas & 2,3 & EC50 & 36,000 & 36,000 & Brooke, 1984 \\
\hline & & & & & Tier II Parameters & Tier II Values \\
\hline & & & & & FAVF & 242 \\
\hline & & & & & SAV & 148.8 \\
\hline & & & & & SACR & 17.9 \\
\hline & & & & & SCV & 8.3 \\
\hline
\end{tabular}

'Because 3-Octanone tests do not have standardard exposure, 2-Octanone tests, which have the standard exposure, were used. 
Table A.1. (continued)

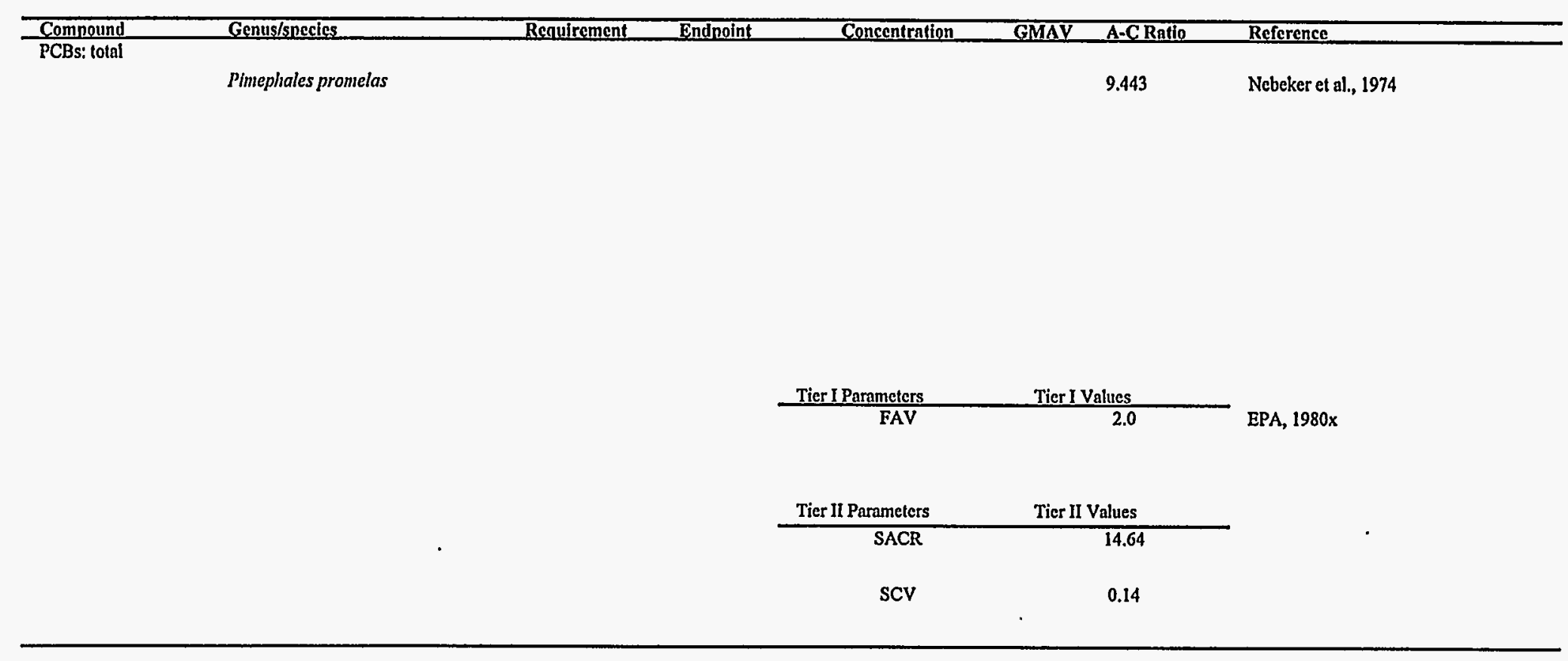




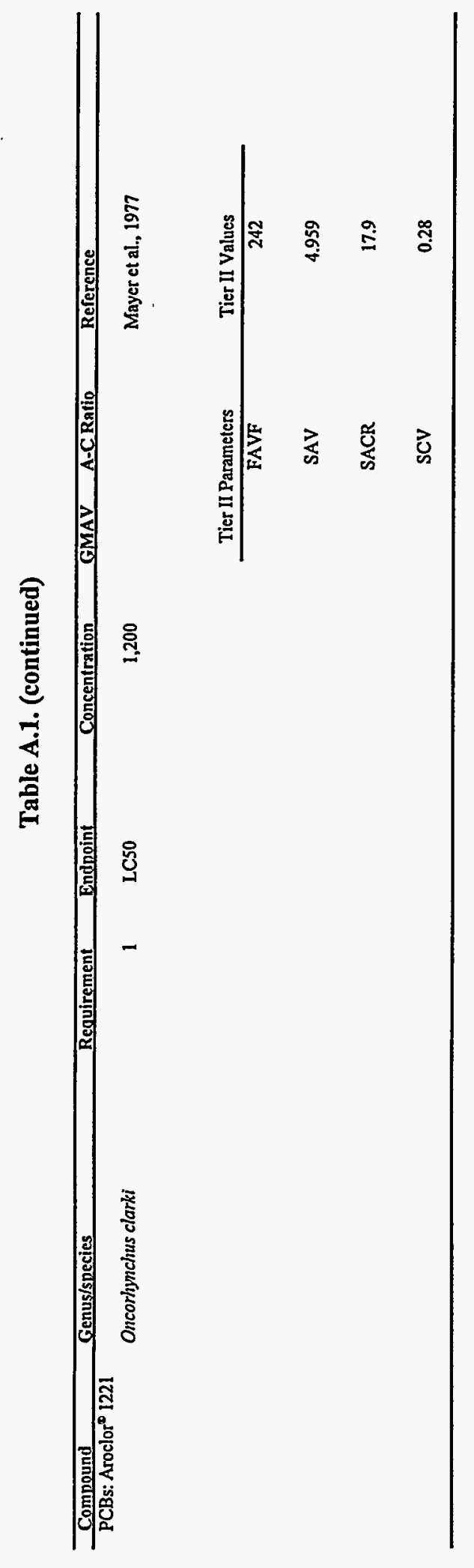


Table A.1. (continued)

\begin{tabular}{|c|c|c|c|c|c|c|}
\hline \multirow{7}{*}{$\begin{array}{l}\text { Cominound } \\
\text { PCBs: Aroclor }{ }^{\mathrm{D}} 1232\end{array}$} & Genus/snecies & Requirement & Enidnoint & Concentration & GMAY A.CRatio & Reference \\
\hline & Oncorhynchus clarki & 1 & LC50 & 2,500 & & Jolunson and Finley, 1980 \\
\hline & & & & & Tier II Parameters & Tier II Values \\
\hline & & & & & FAVF & 242 \\
\hline & & & & & SAV & 10.33 \\
\hline & & & & & SACR & 17.9 \\
\hline & & & $=$ & & SCV & 0.58 \\
\hline
\end{tabular}


Table A.1. (continued)

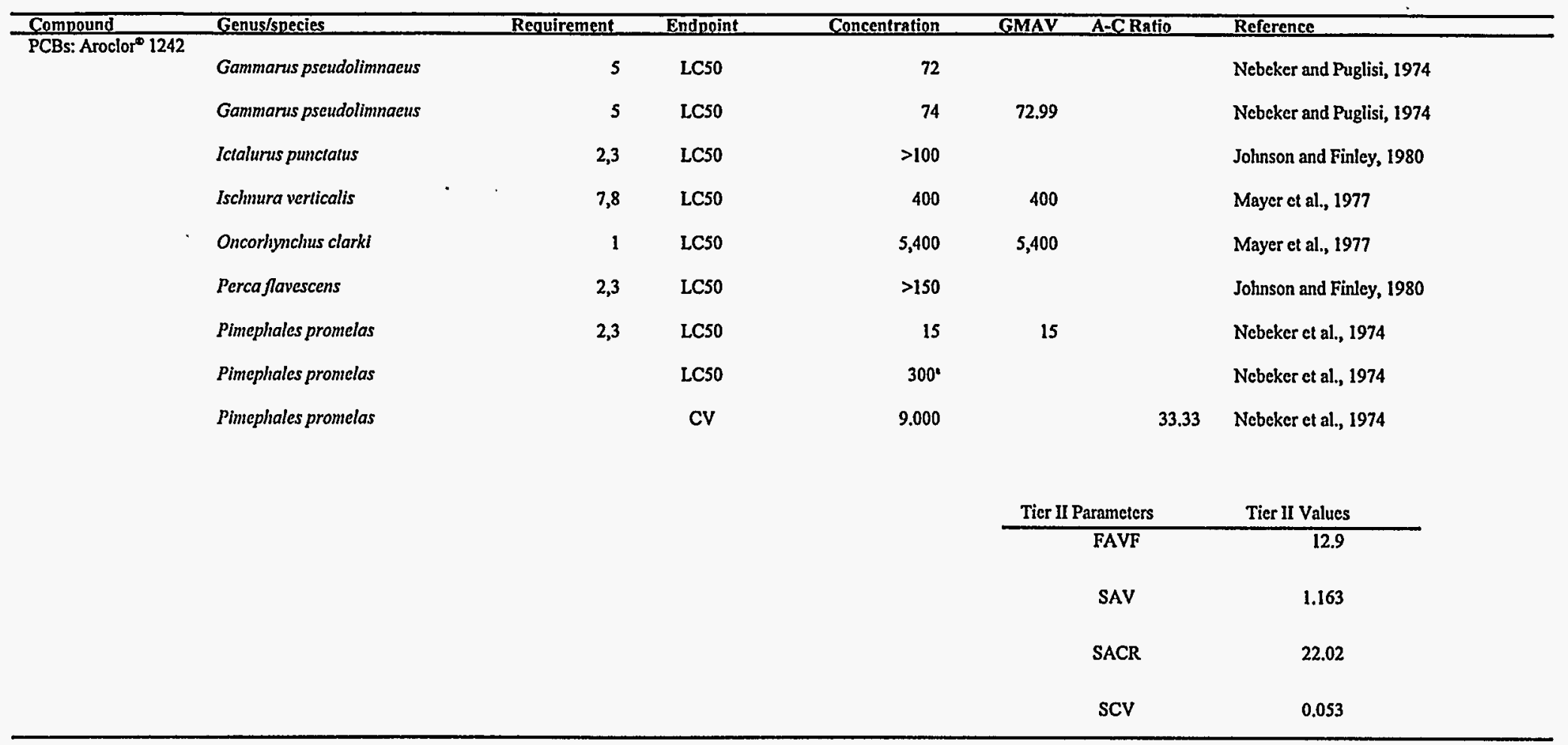

a Because this value is more than ten times of another life stage, it is not used in the GMAV calculation. However, since the preferred life stage in deriving the A-C Ratio is juvenile, it is used in A-C Ratio derivation. 
Table A.1. (continued)

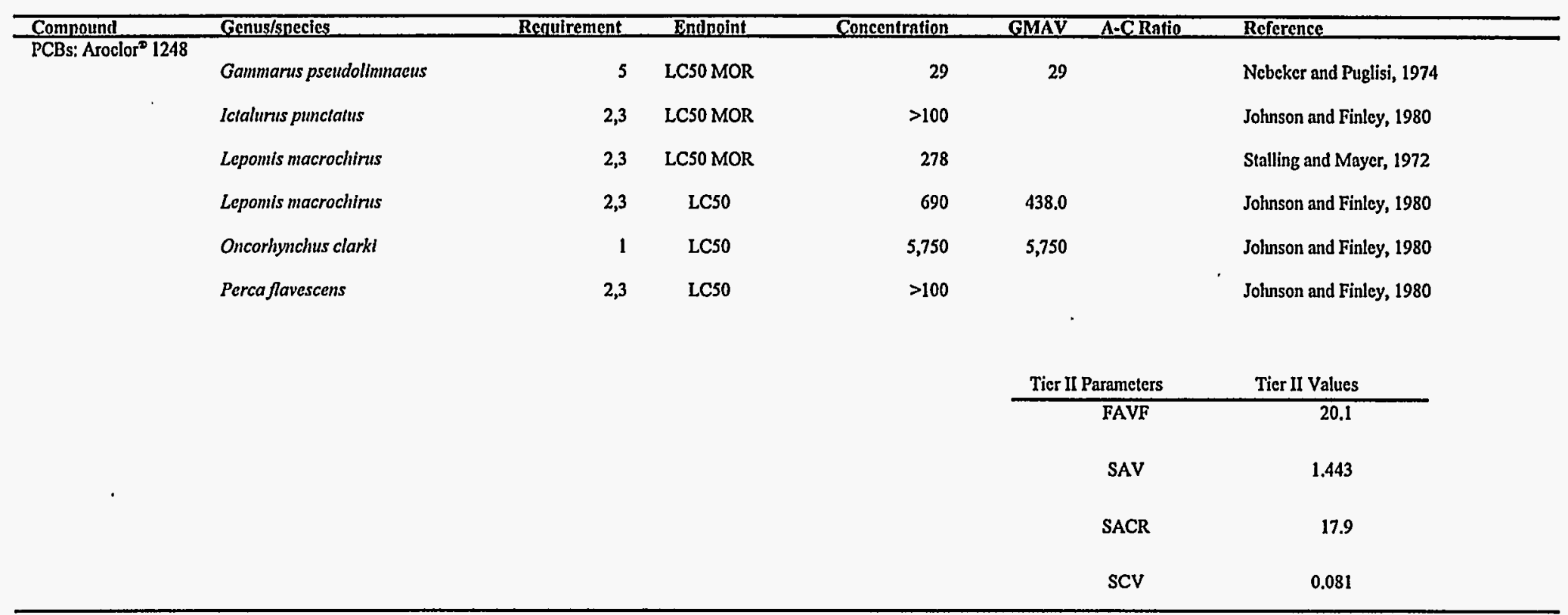


Table A.1. (continued)

\begin{tabular}{|c|c|c|c|c|c|c|c|}
\hline Compound & Genus/species & Requirement & Endpoint & Concentration & GMAV & A-CRatio & Reference \\
\hline \multirow{15}{*}{ PCBs: Aroclor 1254} & Coregonus hoyi & 1 & LC50 & $>10,000$ & & & Passino and Kramer, 1980 \\
\hline & Gammanus fasciatus & 5 & LC50 & 2,400 & 2,400 & & Johnson and Finley, 1980 \\
\hline & Ictalurus punctatus & 2,3 & LC50 & $>200$ & & & Johnson and Finley, 1980 \\
\hline & Ischmura verlicalis & 6 & LC50 & 200 & 200 & & Mayer et al., 1977 \\
\hline & Leponis macrochirus & 2,3 & LC50 & 2,740 & 2,740 & & Jolunson and Finley, 1980 \\
\hline & Oncorhynchus clarki & 1 & LCso & 42,500 & 42,500 & & Johnson and Finley, 1980 \\
\hline & Orconectes nais & 5 & LC50 & 100 & 100 & & Johnson and Finley, 1980 \\
\hline & Perca flavescens & 2,3 & LC50 & $>150$ & & & Jolunson and Finley, 1980 \\
\hline & Pimcphales promelas & 2,3 & LC50 & 7.7 & 7.7 & & Nebeker et al., 1974 \\
\hline & PImephales promelas & & $\mathrm{CV}$ & 2.878 & & 2.676 & Ncbcker et al., 1974 \\
\hline & & & & & Tier II $\mathrm{F}$ & arameters & Tier II Values \\
\hline & & & & & & FAVF & 12.9 \\
\hline & & & & & & SAV & 0.5969 \\
\hline & & & & & & SACR & 17.9 \\
\hline & & & & & & SCV & 0.033 \\
\hline
\end{tabular}


Table A.1. (continued)

\begin{tabular}{|c|c|c|c|c|c|c|}
\hline Compound & Genus/snecies & Requirement & Endnoint & Concentrntion & A-C.Ratio & Reference \\
\hline \multirow{9}{*}{ PCBs: Aroclor ${ }^{\mathrm{D}} 1260$} & Ictalurus punctatus & 2,3 & LC50 & $>400$ & & Johnson and Finlcy, 1980 \\
\hline & Lepomis macrochirus & 2,3 & LC50 & $>400$ & & Jolunson and Finley, 1980 \\
\hline & Oncorhynchus clarkl & I & LC50 & 61,000 & 61,000 & Mayer et al., 1977 \\
\hline & Perca flavescens & 2,3 & LC50 & $>200$ & & Johnson and Finley, 1980 \\
\hline & & & & & Tier II Parameters & Tier II Values \\
\hline & & & & & FAVF & 36.2 \\
\hline & & & & & SAV & 1,685 \\
\hline & . & & & & SACR & 17.9 \\
\hline & & & & & SCV & 94 \\
\hline
\end{tabular}


Table A.1. (continued)

\begin{tabular}{|c|c|c|c|c|c|c|c|}
\hline Compound & Genus/species & Requirement & Endpoint & Concentration & GMAV & A-C ratio & Reference \\
\hline \multirow[t]{6}{*}{ 1-Pentanol } & Pimephales promelas & 2,3 & LC50 & 472,000 & 472,000 & & Geiger et al., 1986 \\
\hline & & & & & & arameters & Tier II Values \\
\hline & & & & & & FAVF & 242 \\
\hline & & & & & & SAV & 1950 \\
\hline & & & & & & SACR & 17.9 \\
\hline & & & & & & scv & 110 \\
\hline
\end{tabular}

'Because 1-pentanol is a volatile compound, only flow-through, measured test was used. 
Table A.1. (continued)

\begin{tabular}{|c|c|c|c|c|c|c|c|}
\hline \multirow{10}{*}{$\begin{array}{l}\text { Compound } \\
\text { 2-Propanol }\end{array}$} & Genus/snecies & Requirement & Endinoint & Concentrafion & GMAV & A-CRntio & Reference \\
\hline & Chironomus riparius & 7 & LC50 & $12,500,000$ & $12,500,000$ & & Roghair et al., 1994 \\
\hline & Pimtephales promelas & 2,3 & LC50 & 10,400 & & & Veith et al., 1983 \\
\hline & Pimephales promelas & 2,3 & LC50 & 9,640 & & & Veith et al,, 1983 \\
\hline & Pimcphales promelas & 2,3 & LC50 & 6,550 & 8,692 & & Brooke et al., 1984 \\
\hline & & & & & Tier II Parameters & & Tier II Values \\
\hline & & & & & FAVF & & 64.8 \\
\hline & & & & & SAV & & 134.1 \\
\hline & & & & & SACR & & 17.9 \\
\hline & & & & & $\mathrm{SCV}$ & . & 7.5 \\
\hline
\end{tabular}


Table A.l. (continued)

\begin{tabular}{|c|c|c|c|c|c|c|c|}
\hline Comnound & Genus/species & Requirement & Endpoint & Concentration & GMAV & A.CRatio & Reference \\
\hline \multicolumn{8}{|c|}{ 1,1,2,2-Tetrachloroethane } \\
\hline & Daphnia magna & 4 & EC50 & 23,000 & 23,000 & & Richter et al., 1983 \\
\hline & Daphmia magna & & cV & 9,829 & & 2.34 & Richter et al., 1983 \\
\hline & Jordanella floridae & 2,3 & LC50 & 18,480 & 18,480 & & Smith et al., 1991 \\
\hline & Jordanella floridac & & CV & 8,467 & & 2.183 & Smith et al., 1991 \\
\hline & Pimephales promelas & 2,3 & LC50 & 20,400 & & & Walbridge et al., 1983 \\
\hline & Pimephales promelas & 2,3 & LC50 & 20,300 & 20,350 & & Geiger et al., 1985 \\
\hline & Pimephales promelas & & $\mathrm{CV}$ & 2,366 & & 8.601 & Ahmad of al., 1984 \\
\hline & & & & & Tier II & Parameters & Tier II Values \\
\hline & & & & & & FAVF & 8.6 \\
\hline & & & & & & SAV & 2,149 \\
\hline & & & & & & SACR & 3.529 \\
\hline & & & & & & SCV & 610 \\
\hline
\end{tabular}

- Because 1,1,2,2-tetrachloroethane is a volatile compound, only flow-lhrough, measured tests were used. 
Table A.1. (continued)

\begin{tabular}{|c|c|c|c|c|c|c|c|c|}
\hline \multirow{15}{*}{$\begin{array}{l}\text { Compound } \\
\text { Tetrachloroethence }\end{array}$} & Genus/snecies & & Requirement & Endinoint & Concentration & GMAV & A-CRnitio & Reference \\
\hline & Daphmia magna & & 4 & EC50 & 8,500 & 8,500 & & Richter et al., 1983 \\
\hline & Daphmia magna & & & $\mathrm{CV}$ & 750.0 & & 11.33 & Richter et al., 1983 \\
\hline & Jordanella floridae & & 2,3 & LC50 & 8,430 & 8,430 & & Smith et al., 1991 \\
\hline & Jordanella foridae & & & $\mathrm{CV}$ & 3,107 & & 2.714 & Smith et al., 1991 \\
\hline & Oncorhynchus nykiss & & 1 & LC50 & 5,840 & & & Shubat et al., 1982 \\
\hline & Oncorhynchus mykiss & & 1 & LC50 & 4,990 & 5,398 & & Shubat et al., 1982 \\
\hline & PImephales promelas & & 2,3 & LC50 & 13,400 & & & Walbridge et al., 1983 \\
\hline & Pimephales promelas & . & 2,3 & LC50 & 20,300 & 16,490 & & Geiger et al., 1985 \\
\hline & Pimephales promelas & & & $\mathrm{CV}$ & 836.7 & & 19.71 & Geiger et al., 1985 \\
\hline & & & & & & Tier II I & arameters & Tier II Values \\
\hline & & & & & & & FAVF & 6.5 \\
\hline & & & & & & & SAV & 830.5 \\
\hline & & & & & & & SACR & 8.463 \\
\hline & & & & & - & & SCV & 98 \\
\hline
\end{tabular}

- Because tetrachloroethene is a yolatile compound, only flow-through, measured tests were used. 
Table A.1. (continued)

\begin{tabular}{|c|c|c|c|c|c|c|c|c|}
\hline Compound & Genus/species & & Requirement & Endpoint & Concentration & GMAV & A-CRatio & Reference \\
\hline \multirow{5}{*}{ Toluene" } & Pimephales promelas & & 23 & LC50 & 31,700 & & & Geiger et al., 1990 \\
\hline & Pimephales promelas & & 2,3 & LC50 & 36,200 & & & Geiger et al., 1986 \\
\hline & Pimephales promelas & & 2,3 & LC50 & 30,000 & & & Devlin et al., 1982 \\
\hline & Pimephales promelas & & 2,3 & LCso & 31,000 & & & Devlin ct al., 1982 \\
\hline & Pimephales promelas & & 2,3 & LC50 & 26,000 & & & Devlin et al., 1982 \\
\hline \multirow[t]{7}{*}{$\cdot$} & Pintephales promelas & $=$ & 2,3 & LC50 & 18,000 & 28,170 & & Devlin et al., 1982 \\
\hline & Pimephales promelas & & & CV & 4,899 & & 5.243 & Devlin ct al., 1982 \\
\hline & & & & & & Tier II & arameters & Tier II Values \\
\hline & & & & & & & FAVF & 242 \\
\hline & & & & & & & SAV & 116.4 \\
\hline & & & & & & & SACR & 11.89 \\
\hline & & & & & & & scV & 9.8 \\
\hline
\end{tabular}

- Because toluene is a volatile compound, only flow-through, measured tests were used. 
A-70

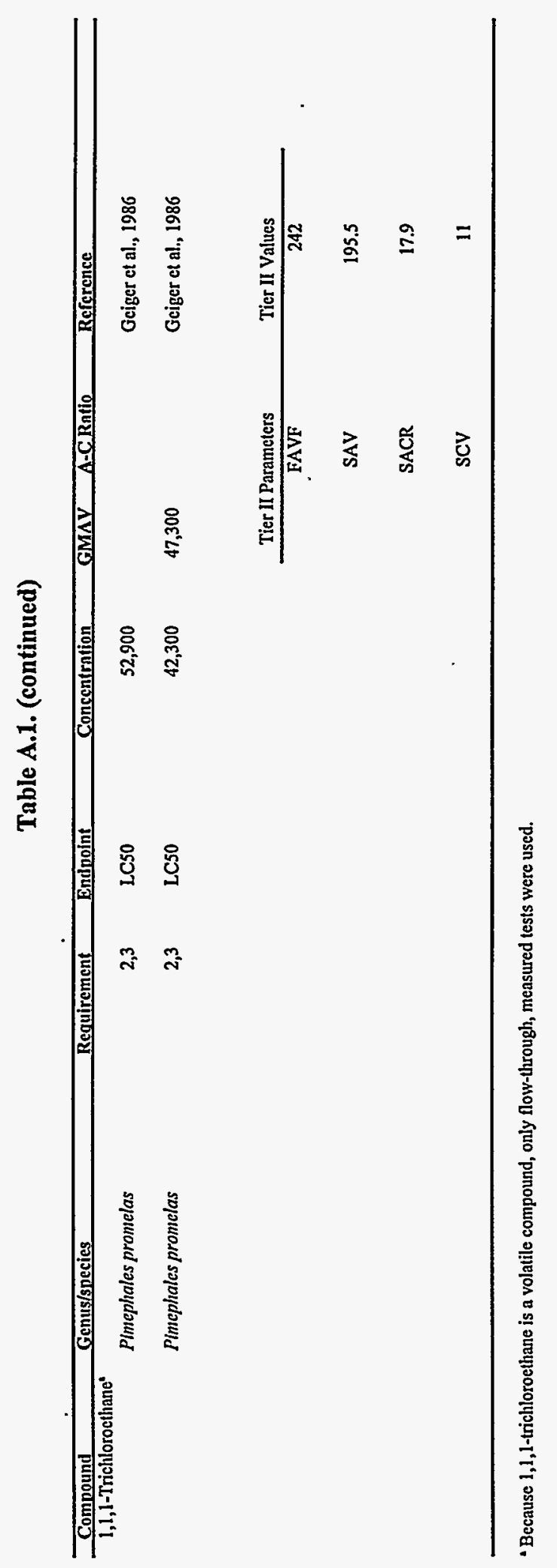


Table A.1. (continued)

\begin{tabular}{|c|c|c|c|c|c|c|c|}
\hline \multirow{11}{*}{$\begin{array}{l}\text { Compound } \\
1,1,2-\text { Trichloroethane" }\end{array}$} & Genus/species & Requirement & Endpoint & Concentration & GMAV & A-C Ratio & Reference \\
\hline & Daphnia magna & 4 & EC50 & 81,000 & 81,000 & & Richter et al., 1983 \\
\hline & Daphnia magna & & $\mathrm{CV}$ & 18,385 & & 4.406 & Richter et al., 1983 \\
\hline & Jordanella floridae & 2,3 & IC5O & 45,117 & 45,117 & & Smith et al., 1991 \\
\hline & Jordanella floridae & & CV & 46,609 & & $2^{b}$ & Smith et al., 1991 \\
\hline & Pimephales promelas & 2,3 & LC50 & 81,600 & 81,600 & & Ahmad et al., 1984 \\
\hline & Pimcphales promelas & & CV & 9,423 & & 8.659 & Ahmad et al., 1984 \\
\hline & & & & & Tier II I & arameters & Tier II Values \\
\hline & & & & & & FAVF & 8.6 \\
\hline & & & & & & SAV & 5,246 \\
\hline & & & & & & SACR & 4.241 \\
\hline & & & & & & SCV & 1200 \\
\hline
\end{tabular}

- Because 1,1,2-trichloroethane is a volatile compound, only flow-through, measured tests were used.

- Since the experimental A.C Ratio is less than 2, the A-C Ratio of J. Joridae is set to 2 (Stephan et al., 1985). 
Table A.1. (continued)

\begin{tabular}{|c|c|c|c|c|c|c|c|}
\hline & Genus/species & Requirement & Endlnoint & Concentration & GMAV & A.CRatio & Reference \\
\hline & Jordanella florldac & 2,3 & LC50 & 28,280 & 28,280 & & Smith ct al., 1991 \\
\hline \multirow{9}{*}{$\begin{array}{l}\text { Compound } \\
\text { Trichloroelhene' }\end{array}$} & Jordanella floridae & & $\mathrm{CV}$ & 11,057 & & 2.558 & Smitls ct al,, 1991 \\
\hline & Pimephales promelas & 2,3 & LC50 & 40,700 & & & Alexander et al., 1978 \\
\hline & Pimephales promelas & 2,3 & LC50 & 45,000 & & & Walbridge ct al., 1983 \\
\hline & Pimephales promelas & 2,3 & LC50 & 44,100 & 43,230 & & Gciger ct al., 1985 \\
\hline & & & & & Tier II & arameters & Tier II Values \\
\hline & & & & & & FAVF & 64.8 \\
\hline & & & & & & SAV & 436.4 \\
\hline & & & & & & SACR & 9.358 \\
\hline & & & & & & SCV & 47 \\
\hline
\end{tabular}

"Because trichloroethene is a volatile compound, only flow-through, measured tests were used. 
Table A.1. (continued)

\begin{tabular}{|c|c|c|c|c|c|c|}
\hline \multirow{19}{*}{$\begin{array}{l}\text { Compound } \\
\text { Vinyl acetate }\end{array}$} & Genus/snecies & Requirement & $\begin{array}{l}\text { Endnoint } \\
\end{array}$ & Concentration & GMAV A-CRatio & Reference \\
\hline & Carassius auratus & 2,3 & LC50 & 42,330 & 42,330 & Pickering and Henderson, 1966 \\
\hline & Lepomis macrochirus & 2,3 & LC50 & 18,000 & 18,000 & Pickering and Henderson, 1966 \\
\hline & Pimephales promelas & 2,3 & LC50 & 14,000 & & Pickering and Henderson, 1966 \\
\hline & Pimephales promelas & 2,3 & LC50 & 15,000 & & Pickering and Henderson, 1966 \\
\hline & Pimephales promelas & 2,3 & LC50 & 14,000 & & Pickering and Henderson, 1966 \\
\hline & Pimephales promelas & 2,3 & LC50 & 15,000 & & Pickering and Henderson, 1966 \\
\hline & Pimephales promelas & 2,3 & LC50 & 15,000 & & Pickering and Henderson, 1966 \\
\hline & Pimephales promelas & 2,3 & LC50 & 23,000 & & Pickering and Henderson, 1966 \\
\hline & Pimephales promelas & 2,3 & LCso & 26,000 & & Pickering and Henderson, 1966 \\
\hline & Pimephales promelas & 2,3 & LC50 & 20,000 & & Pickering and Henderson, 1966 \\
\hline & Pinephales promelas & 2,3 & LC50 & $24,000^{b}$ & & Pickering and Henderson, 1966 \\
\hline & Pimephales promelas & 2,3 & LC50 & $19,730^{6}$ & 18,090 & Pickering and Henderson, 1966 \\
\hline & Poccilla reticulata & 2,3 & LC50 & 31,080 & 31,080 & Pickering and Henderson, 1966 \\
\hline & & & & & Tier II Parameters & Tier II Values \\
\hline & & & & & FAVF & 64.8 \\
\hline & & & & & SAV & 277.8 \\
\hline & & & & & SACR & 17.9 \\
\hline & & & & & SCV & 16 \\
\hline
\end{tabular}

:Althouglt vinyl acetate is a volatile compound, static tests were used because flow-through, measured tests are not available.

- Auther notes hardness influences toxicity; vinyl acetale is more toxic in sof water than hard water. 
Table A.1. (continued)

\begin{tabular}{|c|c|c|c|c|c|c|c|}
\hline Compound & Genus/species & Requirement & Endpoint & Concentration & $\overline{A-C \text { ratio }}$ & Reference & \\
\hline \multicolumn{8}{|l|}{ Xylene' } \\
\hline \multirow{3}{*}{ - } & Lepomis macrochirus & 2,3 & LC50 & 15,700 & 15,700 & Bailey et al., 1985 & \\
\hline & Pimcphales promelas & 2,3 & EC50 & $15,300^{\text {kd }}$ & & Gciger et al., 1990 & \\
\hline & Pimephales promelas & 2,3 & EC50 & $14,800^{\text {sd }}$ & 15,050 & Geiger ct al., 1990 & \\
\hline & & & & & Tier II Parameters & Tier II Values & \\
\hline & & & & & FAVF & 64.8 & \\
\hline & & & & & SAV & 232.3 & \\
\hline & & & & & SACR & 17.9 & \\
\hline & & & & & SCV & 13 & \\
\hline
\end{tabular}

- Because xylene is a volatile compound, only flow-through, measured tests were used.

bo-xylene (99+\% purity) was used.

' $m$-xylene ( $99 \%$ purity) was used.

' Because analytical procedures used at waste sites do not discriminate isomers, toxicity tests on individual and mixture of isomers are considered equivalent. 
Appendix B

METHODS FOR DERIVATION OF TIER II VALUES 



\section{METHODS FOR DERIVATION OF TIER II VALUES}

\section{B.1 Method for data selection}

The procedure used to select and aggregate test data was adopted from the guidelines for deriving National Ambient Water Quality Criteria (NAWQC) (Stephan et al. 1985). The selection criteria are summarized in the following text.

\section{B.1.1 Chemical Considerations}

Not all forms of inorganic chemicals require unique Tier II values. Metal salts with the same oxidation state at ambient conditions (e.g., $\mathrm{BeCl}_{2}$ and $\mathrm{BeSO}_{4}$ ) are expected to exhibit similar toxicity and are given a common Tier II value. Nonionizable, covalently bonded compounds of metals or metals of different oxidation states were considered different chemicals, for which separate Tier II values were derived.

For volatile compounds, only results of flow-through tests with measured chemical concentrations were used, if available. However, if flow-through measured tests were not available, the genus mean acute value (GMAV) was based on static and flow-through unmeasured tests.

Pesticides were screened for commercial formulations; wettable powder, emulsifiable concentrates, and formulated mixtures were eliminated. Only pesticides of technical grades or better were considered.

\section{B.1.2 Dilution water considerations}

Test results were rejected if unusual dilution water was used (e.g., TOC $>5 \mathrm{ppm}$, lack of appropriate salts, low dissolved oxygen), unless toxicity has been demonstrated to be independent of these factors. Tests in which dissolved oxygen fell below $40 \%$ saturation for static or $60 \%$ saturation for flow-through were eliminated.

\section{B.1.3 Biological parameters}

Tests of certain organisms were excluded from the Tier II value derivation. Single-celled organisms and brine shrimp (Artemia sp.) were not used. Fish were generally limited to species with wild North American populations. However, if none of the tests with North American fish were acceptable and values for other organisms were not available, non-resident fish were used.

Tests which did not refer to a standard procedure or indicate use of a control group were excluded. Acute tests in which organisms were fed were eliminated, unless feeding was demonstrated to be independent of toxicity.

For the acute tests, only daphnids and midges (Chironomus sp.) have a specified starting age. Daphnids must be less than 24 hours of age at the start of the test. Midges in second or third instar larvae were preferred, but midge tests starting at fourth instar were accepted. Although the starting age for all other organisms has not been specified, juvenile stages were preferred whenever they were available (unless another life stage is more sensitive to the chemical). All organisms should receive a 96-hour exposure period, except daphnids and midges, where 48 hours is the standard exposure period. The endpoint for daphnids and midges is the EC50 for immobilization. If this is not available, 


\section{B-4}

LC50 is used. For fish, the preferred endpoint is the EC50 for loss of equilibrium, immobilization, and/or mortality. If those are not available, LC50 is used.

In chronic tests, the starting age, exposure duration, and endpoints may be different for daphnids and fish and for salmonids and non-salmonids. Daphnids must be less than 24 hours old at the start of the test, and the test should last at least 21 days. Endpoints are based on mortality and number of young per female.

For a given fish species, preference is given to the following types of chronic tests in the order as follows: full life cycle, partial life cycle, and early life stage. The less desirable chronic test is not included in the calculation if a more desirable type is available.

\section{B.1.4 Variation of Acute Values within the same genus}

If the acute values within a species or among species in a genus differ by a factor of 10 or more, the higher values were excluded, and those that are within the factor of 10 range were used to attain a conservative estimate. If the acute concentrations of a given species differ by a factor of two or more among different life stages, the more sensitive life stage is used to protect the organisms in all life stages.

\section{B.1.5 ACR Considerations}

If the acute chronic ratios (ACRs) for a chemical differ by more than a factor of 10 , the tests were carefully examined to determine whether outliers should be rejected. ACRs from saltwater species should be used along with the freshwater ACRs when less than three ACRs from freshwater species are available. If the lowest GMAV is from larvae of barnacles, bivalves, lobsters, crabs, shrimp, or abalones, the secondary acute chronic ratio (SACR) is assumed to be 2. If an ACR is less than 2, acclimation may have occurred. The ACR is then set to 2.

Preference was given to acute and chronic tests done in the same study. If these are not available, an acute value with water characteristics similar to the chronic value was used. If values from similar water are not available, the GMAV of the species is used with the chronic value to derive an ACR.

If multiple chronic values for a species are available but none are part of the same study as an acute test, the geometric mean of the chronic values was calculated and used with the GMAV to derive an ACR for that species.

\section{B.1.6 Acceptable exposure types and life stage used to derive ACR}

For daphnids, renewal is required for chronic tests; while for acute tests, static exposure is acceptable. All chronic test concentrations should be measured. The life stage of daphnids has to be 24 hours or younger at the start of both acute and chronic tests.

For fish, both acute and chronic tests require flow-through measured tests. For acute fish tests, the life stage of the organism should be juvenile.

\section{B.1.7 Other considerations}

Concentrations above the solubility of chemicals and "greater than" values were used only when at least one definitive concentration was available. 


\section{B.2 Calculation method}

Tier II values are derived if fewer than eight of the acute data requirements or three chronic data requirements presented in EPA (1993a) are met. The eight acute data requirements include:

1. The family Salmonidae in the class Osteichthyes

2. One other family (preferably a commercially, or recreationally important, warmwater species) in the class Osteichthyes (e.g., bluegill, channel catfish, etc.)

3. A third family in the phylum Chordata (e.g., fish, amphibian, etc.)

4. A planktonic crustacean (e.g., a cladocceran, copepod, etc.)

5. A benthic crustacean (e.g., ostracod, isopod, amphipod, crayfish, etc.)

6. An insect (e.g., mayfly, dragonfly, damselfly, stonefly, caddisfly, mosquito, midge, etc.)

7. A family in a phylum other than Arthropoda or Chordata (e.g., Rotifera, Annelida, Mollusca, etc.)

8. A family in any order of insect or any phylum not already represented

If all of these data requirements are not met, then an FAV is calculated. The FAV is a Tier I criterion, and its derivation is documented in Stephan et al. (1985) and in Appendix A of EPA (1993a). The FAV, however, is used in the derivation of the SCV if the chronic data requirements are not met.

Tier II values, as mentioned previously, are calculated when the data requirements are not met. The first calculation of the Tier II criteria is the SAV. The SAV is derived by taking the lowest genus mean acute value (GMAV) for any of the genera present and dividing it by a Final Acute Value Factor (FAVF). The FAVF is selected from Table B.1 where $\mathrm{n}$ is the number of the eight acute data requirements that are satisfied. FAVFs are selected from the two columns depending on whether an acute value (LC50 or EC50) for a daphnid is included in the data set.

Once the SAV is calculated, the Secondary Acute-Chronic Ratio (SACR) is derived. If three or more Acute-Chronic Ratios (ACRs) are present, then the SACR is determined by finding the geometric mean of the ACRs. There must be at least three ACRs. If there are not three chronic values from the literature, then a default value of 17.9 (EPA 1991) is used until the total number of ACRs is three. If multiple ACRs are given for the same genus, then the geometric mean of those ACRs must be calculated. This genus mean ACR can then be used in the derivation of the SACR. Therefore, several members of the same genus can only present one value towards the mandatory three. If no ACRs are given, then the SACR is 17.9.

The final calculation for Tier II values is the derivation of an SCV. The SCV is calculated by dividing the FAV or SAV by the SACR. 


\section{B-6}

Table B.1. Factors for estimation of the Tier II values (EPA 1993 and Stephan 1991)

\begin{tabular}{ccc}
\hline Number of GMAVs $^{\mathbf{a}}$ & $\begin{array}{c}\text { Factor for data sets that } \\
\text { include an acute value for a } \\
\text { daphnid }^{\mathbf{b}}\end{array}$ & $\begin{array}{c}\text { Factors for data sets that do } \\
\text { not include an acute value } \\
\text { for a daphnid }\end{array}$ \\
\hline 1 & 20.5 & 242 \\
2 & 13.2 & 64.8 \\
3 & 8.6 & 36.2 \\
4 & 6.5 & 20.1 \\
5 & 5.0 & 12.9 \\
6 & 4.0 & 9.2 \\
7 & 3.6 & 7.2 \\
\hline
\end{tabular}

GMAV is Genus Mean Acute Value

'Daphnids includes members of the genera Daphnia, Ceriodaphnia, and Simocephalus. 
Appendix C

TABLE SHOWING CONCENTRATIONS ESTIMATED TO CAUSE A 20\% REDUCTION IN THE RECRUIT ABUNDANCE OF LARGEMOUTH BASS, WITH UPPER AND LOWER 95\% CONFIDENCE BOUNDS 

Table C.1. Concentrations estimated to cause a $20 \%$ reduction in the recruit abundance of largemouth bass, with upper and lower $95 \%$ confidence bounds. All units are ug/L

\begin{tabular}{|c|c|c|c|c|c|c|}
\hline Chemical & Test Species & $\begin{array}{l}\text { Test } \\
\text { Type } \\
\end{array}$ & $\begin{array}{l}\text { Lower } \\
95 \% \text { CL } \\
\end{array}$ & Median & $\begin{array}{l}\text { Upper } \\
\text { 95\%CL } \\
\end{array}$ & Source \\
\hline Ammonia & $\begin{array}{l}\text { Fathead minnow } \\
\text { Fathead minnow }\end{array}$ & $\begin{array}{l}\text { Chronic } \\
\text { Chronic }\end{array}$ & $\begin{array}{l}3.98 \\
3.98\end{array}$ & $\begin{array}{l}100 \\
32\end{array}$ & $\begin{array}{l}1585 \\
200\end{array}$ & $\begin{array}{l}\text { Mayes et al. } 1986 \\
\text { Thurston et al. } \\
1986\end{array}$ \\
\hline Antimony & Fathead minnow & Acute & 5.01 & 79 & 501 & EPA 1980b \\
\hline Arsenic III & Fathead minnow & Chronic & 100 & 1995 & 31623 & Call et al. 1983 \\
\hline Arsenic V & $\begin{array}{l}\text { Fathead minnow } \\
\text { Rainbow trout } \\
\text { Mosquitofish }\end{array}$ & $\begin{array}{l}\text { Acute } \\
\text { Acute } \\
\text { Acute }\end{array}$ & $\begin{array}{l}20 \\
10 \\
32\end{array}$ & $\begin{array}{l}159 \\
100 \\
398\end{array}$ & $\begin{array}{l}1000 \\
501 \\
2512\end{array}$ & $\begin{array}{l}\text { EPA 1985a } \\
\text { EPA 1985a } \\
\text { EPA 1985a }\end{array}$ \\
\hline Beryllium & $\begin{array}{l}\text { Fathead minnow } \\
\text { Bluegill } \\
\text { Flagfish } \\
\text { Guppy }\end{array}$ & $\begin{array}{l}\text { Acute } \\
\text { Acute } \\
\text { Acute } \\
\text { Acute }\end{array}$ & $\begin{array}{l}0.35 \\
2.00 \\
2.00 \\
1.58\end{array}$ & $\begin{array}{l}7.08 \\
32 \\
32 \\
25\end{array}$ & $\begin{array}{l}40 \\
126 \\
126 \\
126\end{array}$ & $\begin{array}{l}\text { EPA } 1980 \mathrm{f} \\
\text { EPA } 1980 \mathrm{f} \\
\text { EPA 1980f } \\
\text { EPA } 1980 \mathrm{f}\end{array}$ \\
\hline Cadmium & $\begin{array}{l}\text { Fathead minnow } \\
\text { Bluegill } \\
\text { Brook trout } \\
\text { Brook trout } \\
\text { Flagfish } \\
\text { Flagfish }\end{array}$ & $\begin{array}{l}\text { Chronic } \\
\text { Chronic } \\
\text { Chronic } \\
\text { Chronic } \\
\text { Chronic } \\
\text { Chronic }\end{array}$ & $\begin{array}{l}1 \\
1.99 \\
0.13 \\
0.32 \\
0.63 \\
0.79\end{array}$ & $\begin{array}{l}10 \\
13 \\
1.26 \\
3.16 \\
3.98 \\
3.16\end{array}$ & $\begin{array}{l}79 \\
50 \\
6.31 \\
25 \\
50 \\
7.94\end{array}$ & $\begin{array}{l}\text { Pickering and Gast } 1972 \\
\text { Eaton } 1974 \\
\text { Benoit et al. } 1976 \\
\text { Sauter et al. } 1976 \\
\text { Carlson et al. } 1982 \\
\text { Spehar } 1976\end{array}$ \\
\hline Chromium III & Rainbow trout & Chronic & 13 & 126 & 1000 & $\begin{array}{l}\text { Stevens and Chapman } \\
1984\end{array}$ \\
\hline Chromium VI & $\begin{array}{l}\text { Fathead minnow } \\
\text { Rainbow trout }\end{array}$ & $\begin{array}{l}\text { Chronic } \\
\text { Chronic }\end{array}$ & $\begin{array}{l}25 \\
100\end{array}$ & $\begin{array}{l}158 \\
631\end{array}$ & $\begin{array}{l}1260 \\
5010\end{array}$ & $\begin{array}{l}\text { Pickering } 1980 \\
\text { Sauter et al. } 1976\end{array}$ \\
\hline Cobalt & Fathead minnow & Acute & 0.16 & 3.98 & 32 & Lind ct al. 1978 \\
\hline Copper & $\begin{array}{l}\text { Fathead minnow } \\
\text { Fathead minnow } \\
\text { Bluegill } \\
\text { Brook trout } \\
\\
\text { Brook trout } \\
\text { Colno salmon }\end{array}$ & $\begin{array}{l}\text { Chronic } \\
\text { Chronic } \\
\text { Chronic } \\
\text { Chronic } \\
\text { Chronic } \\
\text { Chronic }\end{array}$ & $\begin{array}{l}0.40 \\
0.32 \\
1.995 \\
1\end{array}$ & $\begin{array}{l}3.98 \\
3.16 \\
13 \\
3.98\end{array}$ & $\begin{array}{l}40 \\
16 \\
50 \\
16 \\
\\
40 \\
316\end{array}$ & $\begin{array}{l}\text { Mount } 1968 \\
\text { Mount and Stephan } 1969 \\
\text { Benoit } 1975 \\
\text { McKim and Benoit } \\
1971 \\
\text { Sauter et al. } 1976 \\
\text { Hazel and Meith } 1970\end{array}$ \\
\hline
\end{tabular}


Table C.1. (continued)

\begin{tabular}{|c|c|c|c|c|c|c|}
\hline Chemical & Test Species & $\begin{array}{l}\text { Test } \\
\text { Type }\end{array}$ & $\begin{array}{l}\text { Lower } \\
95 \% \mathrm{CL} \\
\end{array}$ & Median & $\begin{array}{l}\text { Upper } \\
\text { 95\%CL } \\
\end{array}$ & Source \\
\hline & Rainbow trout & Chronic & 3.98 & 32 & 200 & Seim et al. 1984 \\
\hline Cyanide & $\begin{array}{l}\text { Fathead minnow } \\
\text { Atlantic Salmon } \\
\text { Blucgill } \\
\text { Brook trout }\end{array}$ & $\begin{array}{l}\text { Chronic } \\
\text { Chronic } \\
\text { Chronic } \\
\text { Chronic }\end{array}$ & $\begin{array}{l}0.20 \\
1.99 \\
5.01 \\
1.58\end{array}$ & $\begin{array}{l}2.51 \\
16 \\
25 \\
13\end{array}$ & $\begin{array}{l}16 \\
200 \\
158 \\
79\end{array}$ & $\begin{array}{l}\text { Smith et al. } 1979 \\
\text { Leduc } 1978 \\
\text { Smith et al. } 1979 \\
\text { Smith et al. } 1979\end{array}$ \\
\hline Lead & $\begin{array}{l}\text { Brook trout } \\
\text { Rainbow trout }\end{array}$ & Chronic & 13 & 100 & 316 & $\begin{array}{l}\text { Holcombe et al. } \\
1976 \\
\text { Sauter et al. } 1976\end{array}$ \\
\hline Manganese & Fathead minnow & Acute & 11 & 112 & 794 & Kimball n.d. \\
\hline Mercury, inorganic & $\begin{array}{l}\text { Fathead minnow } \\
\text { Fathead minnow }\end{array}$ & $\begin{array}{l}\text { Chronic } \\
\text { Chronic }\end{array}$ & $\begin{array}{l}0.04 \\
0.01\end{array}$ & $\begin{array}{l}0.79 \\
0.13\end{array}$ & $\begin{array}{l}13 \\
3.16\end{array}$ & $\begin{array}{l}\text { Call et al. } 1983 \\
\text { Snarski and Olson } 1982\end{array}$ \\
\hline Mercury, methyl & $\begin{array}{l}\text { Rainbow trout } \\
\text { Brook trout }\end{array}$ & $\begin{array}{l}\text { Acute } \\
\text { Acute }\end{array}$ & $\begin{array}{l}0.004 \\
0.02\end{array}$ & $\begin{array}{l}0.16 \\
0.50\end{array}$ & $\begin{array}{l}1.26 \\
3.98\end{array}$ & $\begin{array}{l}\text { EPA 1985e } \\
\text { EPA 1985e }\end{array}$ \\
\hline Nickel & $\begin{array}{l}\text { Fathead minnow } \\
\text { Rainbow trout } \\
\text { Rainbow trout }\end{array}$ & $\begin{array}{l}\text { Chronic } \\
\text { Chronic } \\
\text { Chronic }\end{array}$ & $\begin{array}{l}32 \\
13 \\
126\end{array}$ & $\begin{array}{l}126 \\
63 \\
1260\end{array}$ & $\begin{array}{l}501 \\
398 \\
15800\end{array}$ & $\begin{array}{l}\text { Pickering } 1974 \\
\text { Nebeker et al. } 1985 \\
\text { Nebeker et al. } 1985\end{array}$ \\
\hline Silver & Fathead minnow & Chronic & 0.01 & 0.1 & 1 & Holcombe et al. 1983 \\
\hline & Rainbow trout & Chronic & 0.1 & 1 & 7.94 & Nebeker et al. 1983 \\
\hline Thallium & $\begin{array}{l}\text { Fathead minnow } \\
\text { Blucgill }\end{array}$ & $\begin{array}{l}\text { Acute } \\
\text { Acutc }\end{array}$ & $\begin{array}{l}0.25 \\
73\end{array}$ & $\begin{array}{l}4.47 \\
1000\end{array}$ & $\begin{array}{l}40 \\
6310\end{array}$ & $\begin{array}{l}\text { EPA 1980bb } \\
\text { EPA } 1980 b b\end{array}$ \\
\hline Uranium & $\begin{array}{l}\text { Fathead minnow } \\
\text { Fathead minnow } \\
\text { Fathead minnow } \\
\text { Fathead minnow }\end{array}$ & $\begin{array}{l}\text { Acute } \\
\text { Acute } \\
\text { Acute } \\
\text { Acute }\end{array}$ & $\begin{array}{l}0.398 \\
0.501 \\
0.631 \\
32\end{array}$ & $\begin{array}{l}10 \\
10 \\
13 \\
398\end{array}$ & $\begin{array}{l}50 \\
50 \\
79 \\
3980\end{array}$ & $\begin{array}{l}\text { Cushman et al. } 1977 \\
\text { Cushman et al. } 1977 \\
\text { Cushman et al. } 1977 \\
\text { Cushman et al. } 1977\end{array}$ \\
\hline Vanadium & $\begin{array}{l}\text { Fathead minnow } \\
\text { Brook trout } \\
\text { Flagfish }\end{array}$ & $\begin{array}{l}\text { Acute } \\
\text { Acute } \\
\text { Acute }\end{array}$ & $\begin{array}{l}0.28 \\
5.01 \\
10\end{array}$ & $\begin{array}{l}5.01 \\
63 \\
100\end{array}$ & $\begin{array}{l}40 \\
398 \\
501\end{array}$ & $\begin{array}{l}\text { Kimball n.d. } \\
\text { Emst and Garside } 1987 \\
\text { Holdway and Sprague } \\
1979\end{array}$ \\
\hline Zinc & Fathead minnow & Chronic & 3.98 & 40 & 316 & $\begin{array}{l}\text { Benoit and Holcombe } \\
1978\end{array}$ \\
\hline
\end{tabular}


Table C.1. (continued)

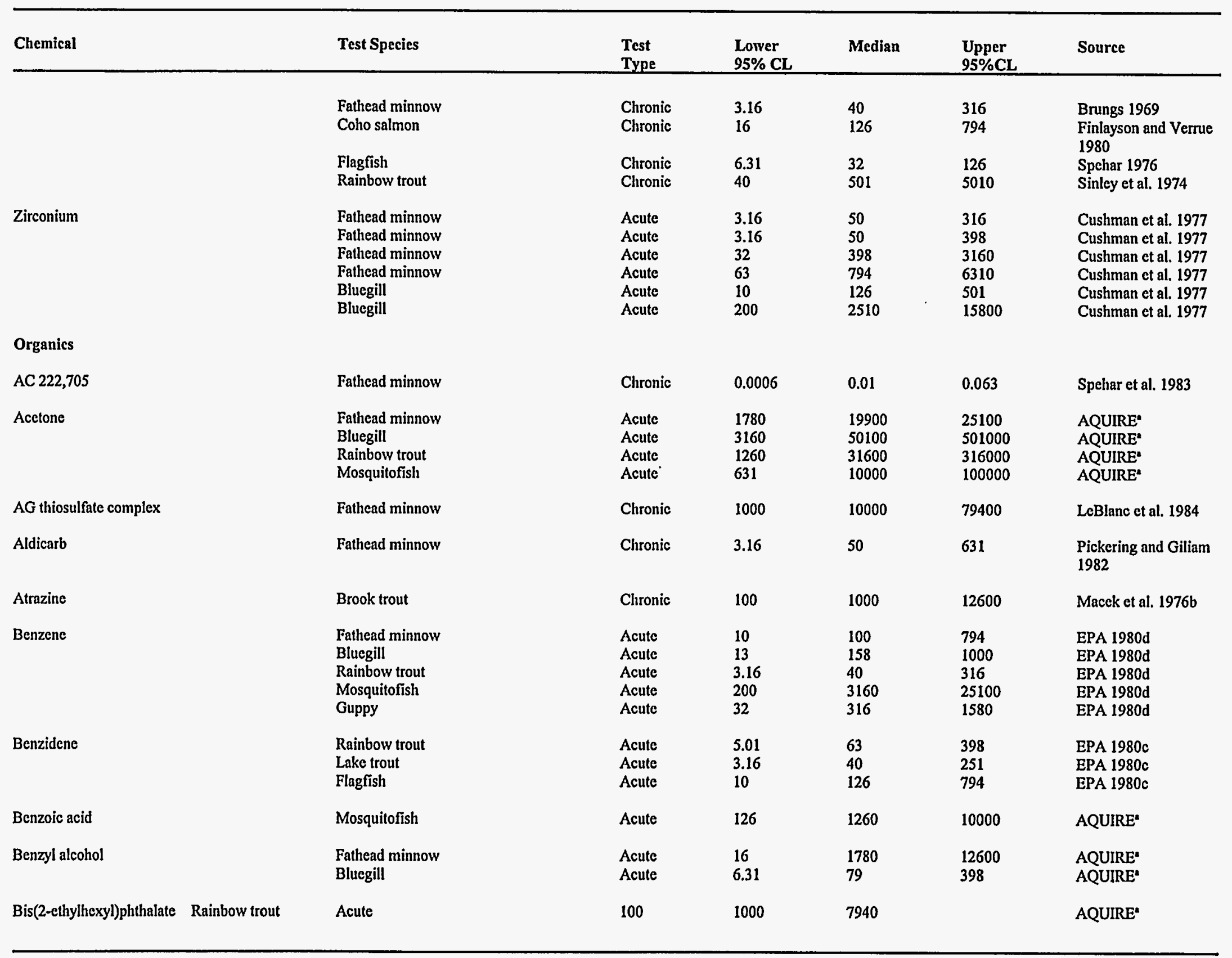


Table C.1. (continued)

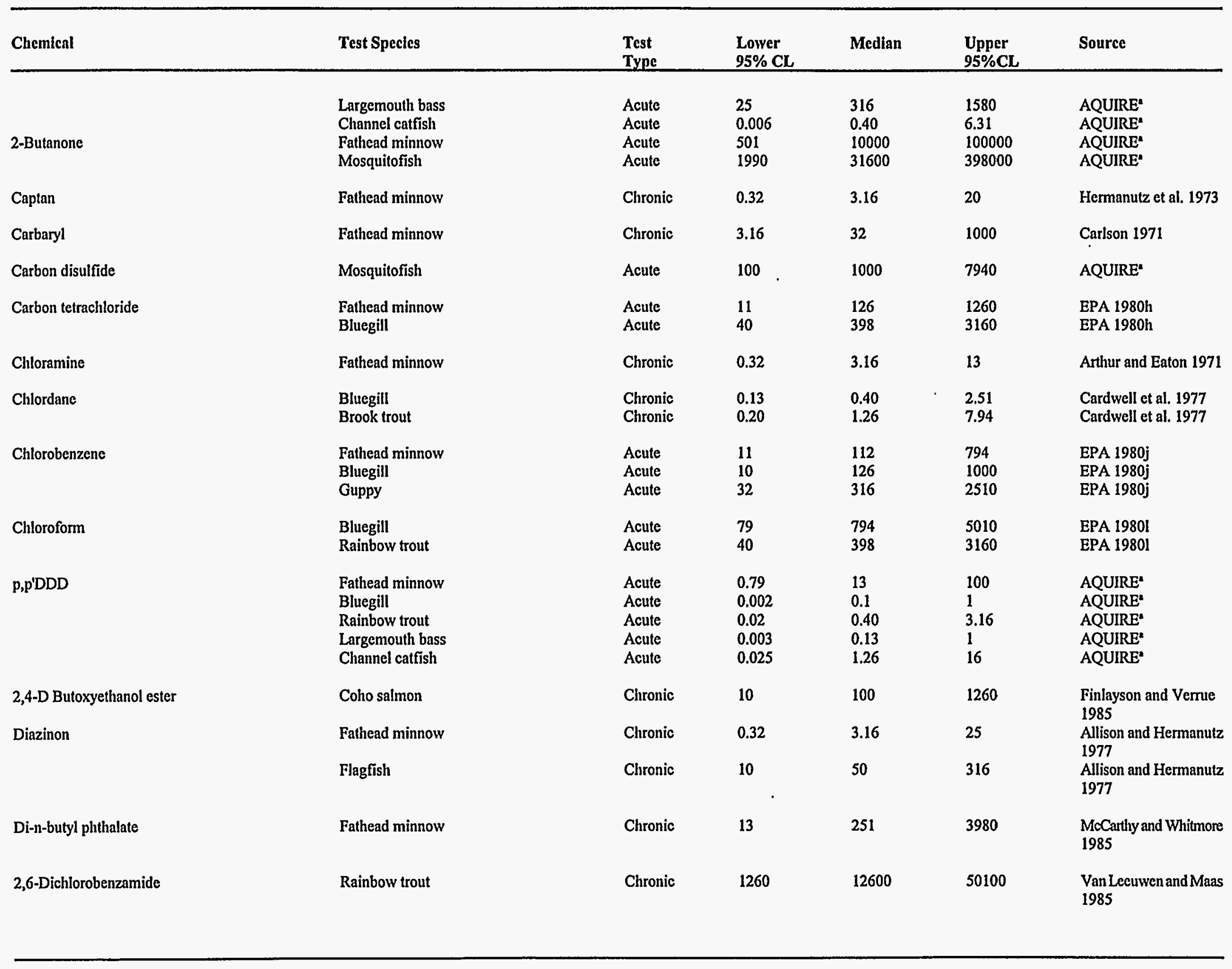


Table C.1. (continued)

\begin{tabular}{|c|c|c|c|c|c|c|}
\hline Chemical & Test Species & $\begin{array}{l}\text { Test } \\
\text { Type } \\
\end{array}$ & $\begin{array}{l}\text { Lower } \\
95 \% \text { CL } \\
\end{array}$ & Median & $\begin{array}{l}\text { Upper } \\
\mathbf{9 5 \% C L} \\
\end{array}$ & Source \\
\hline 1,3-Dichlorobenzene & Fathead minnow & Chronic & 316 & 1585 & 15849 & Ahmad et al. 1984 \\
\hline 1,4-Dichlorobenzene & Fathead minnow & Chronic & 32 & 398 & 6310 & Ahmad et al. 1984 \\
\hline 1,1-Dichloroethane & Guppy & Acute & 158 & 1580 & 12600 & AQUIRE" \\
\hline 1,2-Dichloroethane & $\begin{array}{l}\text { Fathead minnow } \\
\text { Bluegill }\end{array}$ & $\begin{array}{l}\text { Acute } \\
\text { Acute }\end{array}$ & $\begin{array}{l}40 \\
316\end{array}$ & $\begin{array}{l}398 \\
3980\end{array}$ & $\begin{array}{l}3160 \\
31600\end{array}$ & $\begin{array}{l}\text { EPA 1980k } \\
\text { EPA 1980k }\end{array}$ \\
\hline 1,1-Dichlorocthene & $\begin{array}{l}\text { Fathead minnow } \\
\text { Bluegill }\end{array}$ & $\begin{array}{l}\text { Acute } \\
\text { Acute }\end{array}$ & $\begin{array}{l}40 \\
50\end{array}$ & $\begin{array}{l}398 \\
501\end{array}$ & $\begin{array}{l}3160 \\
3980\end{array}$ & $\begin{array}{l}\text { EPA 1980n } \\
\text { EPA.1980n }\end{array}$ \\
\hline 2,4-Dichlorophenol & Fathead minnow & Chronic & 32 & 200 & 1580 & Holcombe et al. 1982 \\
\hline 1,2-Dichloropropane & Fathead minnow & Chronic & 398 & 3980 & 39800 & Benoit et al. 1982 \\
\hline 1,3-Dichloropropane & Fathead minnow & Chronic & 501 & 5010 & 50100 & Benoit et al. 1982 \\
\hline 1,3-Dichloropropene & Blucgill & Acute & 3.16 & 40 & 251 & EPA 19800 \\
\hline Diethyl phthalate & Bluegill & Acute & 79 & 1000 & 6310 & AQUIRE \\
\hline $\begin{array}{l}\text { 2,4-Dimethylphenol } \\
\text { Dimethyl phithalate }\end{array}$ & $\begin{array}{l}\text { Fathead minnow } \\
\text { Rainbow trout }\end{array}$ & $\begin{array}{l}\text { Chronic } \\
\text { Chronic }\end{array}$ & $\begin{array}{l}100 \\
0.004\end{array}$ & $\begin{array}{l}1260 \\
0.04\end{array}$ & $\begin{array}{l}19900 \\
0.40\end{array}$ & $\begin{array}{l}\text { Holcombe et al. } 1982 \\
\text { Ward and Boeri } 1991 \mathrm{~b}\end{array}$ \\
\hline 1,3-Dinitrobenzene & $\begin{array}{l}\text { Rainbow trout } \\
\text { Rainbow trout }\end{array}$ & $\begin{array}{l}\text { Chronic } \\
\text { Chronic }\end{array}$ & $\begin{array}{l}100 \\
63\end{array}$ & $\begin{array}{l}1000 \\
794\end{array}$ & $\begin{array}{l}7940 \\
6310\end{array}$ & $\begin{array}{l}\text { Van Der Schalic } 1983 \\
\text { Van Der Schalie } 1983\end{array}$ \\
\hline Dinoseb & Fathead minnow & Chronic & 0.13 & 3.16 & 40 & Call et al. 1983 \\
\hline Di-n-octyl phthalate & Fathead minnow & Chronic & 200 & 1990 & 39800 & $\begin{array}{l}\text { MeCarthy and Whitmore } \\
1985\end{array}$ \\
\hline Diuron & Fathead minnow & Chronic & 1 & 16 & 158 & Call et al. 1983 \\
\hline Dursban & Fathead minnow & Chronic & 0.002 & 0.032 & 0.20 & Jarvinen et al. 1983 \\
\hline DNBP & Rainbow trout & Chronic & 0.00004 & 0.0004 & 0.005 & Ward and Boeri 1991a \\
\hline Endrin & Fathead minnow & Chronic & 0.005 & 0.13 & 1.58 & Carlson et al. 1982 \\
\hline Endosulfan & Fathead minnow & Chronic & 0.002 & 0.016 & 0.13 & Macek et al. $1976 \mathrm{~b}$ \\
\hline Ethyl benzene & $\begin{array}{l}\text { Fathead minnow } \\
\text { Bluegill }\end{array}$ & $\begin{array}{l}\text { Acute } \\
\text { Acute }\end{array}$ & $\begin{array}{l}10 \\
50\end{array}$ & $\begin{array}{l}158 \\
501\end{array}$ & $\begin{array}{l}1000 \\
3980\end{array}$ & $\begin{array}{l}\text { EPA 1980p } \\
\text { EPA 1980p }\end{array}$ \\
\hline
\end{tabular}


Table C.1. (continued)

\begin{tabular}{|c|c|c|c|c|c|c|}
\hline Chemical & Test Species & $\begin{array}{l}\text { Test } \\
\text { Type } \\
\end{array}$ & $\begin{array}{l}\text { Lower } \\
95 \% \mathrm{CL} \\
\end{array}$ & Median & 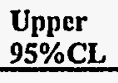 & Source \\
\hline & Guppy & Acute & 79 & 794 & 5010 & EPA 1980p \\
\hline Fenitrothion & Fathead minnow & Clironic & 0.1 & 126 & 1990 & Kleiner et al. 1984 \\
\hline Fluoranthene & Bluegill & Acute & 2.00 & 32 & 126 & EPA $1980 q$ \\
\hline Fluridone & Fathead minnow & Chronic & 32 & 398 & 10000 & Hamelink et al. 1986 \\
\hline Fonofos & Fathead minnow & Chronic & 3.16 & 20 & 158 & $\begin{array}{l}\text { Pickering and Giliam } \\
1982\end{array}$ \\
\hline $\begin{array}{l}\text { Guthion } \\
\text { Heptachlor }\end{array}$ & $\begin{array}{l}\text { Fathead minnow } \\
\text { Fathead minnow }\end{array}$ & $\begin{array}{l}\text { Chronic } \\
\text { Chronic }\end{array}$ & $\begin{array}{l}0.013 \\
0.01\end{array}$ & $\begin{array}{l}0.13 \\
0.1\end{array}$ & $\begin{array}{l}3.98 \\
0.63\end{array}$ & $\begin{array}{l}\text { Adelman et al. } 1976 \\
\text { Macek et al. } 1976 \mathrm{~b}\end{array}$ \\
\hline Hexachlorobutadiene & Fathead minnow & Chronic & 0.32 & 3.98 & 63 & Benoit et al. 1982 \\
\hline Hexachlorocyclohexane (lindane) & $\begin{array}{l}\text { Bluegill } \\
\text { Macek et al. 1976a }\end{array}$ & Chronic & 0.16 & 1 & 6.31 & \\
\hline Hexachloroethane & Fathead minnow & Chronic & 3.98 & 100 & 1580 & Ahmad et al. 1984 \\
\hline 2-Hexanone & Fathead minnow & Acute & 100 & 1260 & 12600 & AQUIRE" \\
\hline Kelthane & Fathead minnow & Chronic & 0.32 & 7.94 & 100 & Spehar et al. 1982 \\
\hline LAS 11.2 & Fathead minnow & Chronic & 126 & 1580 & 25100 & Holman et al. 1980 \\
\hline LAS 11.7 & Fathead minnow & Chronic & 13 & 200 & 2510 & Holman et al. 1980 \\
\hline LAS Mixture & Fathead minnow & Chronic & 20 & 316 & 1580 & $\begin{array}{l}\text { Pickering and Thatcher } \\
1970\end{array}$ \\
\hline Malathion & Flagfish & Chronic & 3.162 & 20 & 126 & Hermanutz 1978 \\
\hline 1-Methylnaphthalene & Fathead minnow & Acute & 1.78 & 31.62 & 200 & AQUIRE' \\
\hline 4-Methyl-2-pentanone & Fathead minnow & Acute & 141 & 1580 & 15800 & AQUIREa \\
\hline 2-Methylphenol & $\begin{array}{l}\text { Fathead minnow } \\
\text { Bluegill } \\
\text { Rainbow trout }\end{array}$ & $\begin{array}{l}\text { Acute } \\
\text { Acute } \\
\text { Acute }\end{array}$ & $\begin{array}{l}3.98 \\
13 \\
6.31\end{array}$ & $\begin{array}{l}40 \\
126 \\
79\end{array}$ & $\begin{array}{l}398 \\
1000 \\
398\end{array}$ & $\begin{array}{l}\text { AQUIRE } \\
\text { AQUIRE } \\
\text { AQUIRE }\end{array}$ \\
\hline Methylene chloride & $\begin{array}{l}\text { Fathead minnow } \\
\text { Bluegill }\end{array}$ & $\begin{array}{l}\text { Acute } \\
\text { Acute }\end{array}$ & $\begin{array}{l}63.10 \\
158\end{array}$ & $\begin{array}{l}1000 \\
1580\end{array}$ & $\begin{array}{l}10000 \\
12600\end{array}$ & $\begin{array}{l}\text { AQUIRE" } \\
\text { AQUIRE" }\end{array}$ \\
\hline
\end{tabular}


Table C.1. (continued)

\begin{tabular}{|c|c|c|c|c|c|c|}
\hline Chemical & Test Species & $\begin{array}{l}\text { Test } \\
\text { Type }\end{array}$ & $\begin{array}{l}\text { Lower } \\
95 \% \text { CL }\end{array}$ & Median & $\begin{array}{l}\text { Upper } \\
95 \% \mathrm{CL}\end{array}$ & Source \\
\hline Naphthalene & Fathead minnow & Chronic & 73 & 1000 & 12600 & DeGraeve et al. 1982 \\
\hline 4-Nitrophenol & $\begin{array}{l}\text { Fathead minnow } \\
\text { Bluegill } \\
\text { Rainbow trout } \\
\text { Channel catfish }\end{array}$ & $\begin{array}{l}\text { Acute } \\
\text { Acute } \\
\text { Acute } \\
\text { Acute }\end{array}$ & $\begin{array}{l}13 \\
3.98 \\
6.31 \\
0.79\end{array}$ & $\begin{array}{l}159 \\
50 \\
79 \\
20\end{array}$ & $\begin{array}{l}1260 \\
316 \\
398 \\
200\end{array}$ & $\begin{array}{l}\text { AQUIRE" } \\
\text { AQUIRE" } \\
\text { AQUIRE" } \\
\text { AQUIRE" }\end{array}$ \\
\hline $\mathrm{N}$-nitrosodiphenylamine & Bluegill & Acute & 3.16 & 40 & 251 & AQUIRE" \\
\hline PCBs: Aroclor 1221 & Cutthroat trout & Acute & 0.63 & 10 & 50 & AQUIRE" \\
\hline PCBs: Aroclor 1232 & Cutthroat trout & Acute & 1.26 & 16 & 126 & AQUIRE* \\
\hline PCBs: Aroclor 1242 & Fathead minnow & Clrronic & 0.13 & 1.58 & 40 & Nebeker et al. 1974 \\
\hline PCBs: Aroclor 1248 & Flagfish & Clironic & 0.13 & 1.26 & 7.94 & Nebeker et al. 1974 \\
\hline PCBs: Aroclor 1254 & Fathead minnow & Chronic & 0.1 & 0.63 & 7.94 & Nebeker et al. 1974 \\
\hline PCBs: Aroclor 1260 & Cutthroat trout & Acute & 32 & 316 & 2510 & AQUIRE" \\
\hline Pentachloroethane & Fathead minnow & Chronic & 100 & 1260 & 19900 & Ahmad et al. 1984 \\
\hline Pentachlorophenol & $\begin{array}{l}\text { Fathead minnow } \\
\text { Fathead minnow } \\
\text { Fathead minnow } \\
\text { Fathead minnow } \\
\text { Fathead minnow } \\
\text { Rainbow trout }\end{array}$ & $\begin{array}{l}\text { Chronic } \\
\text { Chronic } \\
\text { Chronic } \\
\text { Chronic } \\
\text { Chronic } \\
\text { Chronic }\end{array}$ & $\begin{array}{l}1.58 \\
0.32 \\
0.63 \\
1.26 \\
1.99 \\
1.58\end{array}$ & $\begin{array}{l}32 \\
1.99 \\
6.31 \\
13 \\
16 \\
10\end{array}$ & $\begin{array}{l}501 \\
20 \\
63 \\
126 \\
158 \\
50\end{array}$ & $\begin{array}{l}\text { Holcombe et al. } 1982 \\
\text { Spehar et al. } 1985 \\
\text { Spehar et al. } 1985 \\
\text { Spchar et al. } 1985 \\
\text { Spehar et al. } 1985 \\
\text { Dominguezand Chapman } \\
\text { 1984 }\end{array}$ \\
\hline 1-Pentanol & $\begin{array}{l}\text { Bluegill } \\
\text { Rainbow trout }\end{array}$ & $\begin{array}{l}\text { Acute } \\
\text { Acute }\end{array}$ & $\begin{array}{l}398 \\
200\end{array}$ & $\begin{array}{l}5010 \\
2510\end{array}$ & $\begin{array}{l}39800 \\
19900\end{array}$ & $\begin{array}{l}\text { AQUIRE" } \\
\text { AQUIRE" }\end{array}$ \\
\hline Permethrin & Fathead minnow & Chronic & 0.02 & 0.40 & 5.01 & Spehar et al. 1983 \\
\hline Phenol & $\begin{array}{l}\text { Fathead minnow } \\
\text { Rainbow trout }\end{array}$ & $\begin{array}{l}\text { Chronic } \\
\text { Chronic }\end{array}$ & $\begin{array}{l}1000 \\
126\end{array}$ & $\begin{array}{l}12600 \\
1580\end{array}$ & $\begin{array}{l}199000 \\
15800\end{array}$ & $\begin{array}{l}\text { Degraeve et al. } 1980 \\
\text { Degraeve et al. } 1980\end{array}$ \\
\hline Propanil & Fathead minnow & Chronic & 0.01 & 0.1 & 0.63 & Call et al. 1983 \\
\hline 2-Propanol & Fathead minnow & Acute & 200 & 3160 & 31600 & AQUIRE \\
\hline Pydrin & Fathead minnow & Chronic & 0.006 & 0.13 & 1.58 & Spchar et al. 1982 \\
\hline
\end{tabular}


Table C.1. (continued)

\begin{tabular}{|c|c|c|c|c|c|c|}
\hline Chemical & Test Species & $\begin{array}{l}\text { Test } \\
\text { Type } \\
\end{array}$ & $\begin{array}{l}\text { Lower } \\
95 \% \text { CL } \\
\end{array}$ & Median & $\begin{array}{l}\text { Upper } \\
\text { 95\%CL } \\
\end{array}$ & Source \\
\hline 1,1,2,2-Tetrachloroethane & Fathcad minnow & Chronic & 251 & 1580 & 50100 & Ahmad et al. 1984 \\
\hline Tetrachloroethene & $\begin{array}{l}\text { Fathead minnow } \\
\text { Bluegill } \\
\text { Rainbow trout }\end{array}$ & $\begin{array}{l}\text { Acute } \\
\text { Acute } \\
\text { Acute }\end{array}$ & $\begin{array}{l}3.16 \\
10 \\
3.16\end{array}$ & $\begin{array}{l}50 \\
100 \\
40\end{array}$ & $\begin{array}{l}398 \\
501 \\
316\end{array}$ & $\begin{array}{l}\text { EPA 1980aa } \\
\text { EPA 1980aa } \\
\text { EPA 1980aa }\end{array}$ \\
\hline Tetrachloroethylene & Fathead minnow & Chronic & 40 & 1000 & $12600^{\circ}$ & Ahmad et al. 1984 \\
\hline Toluene & $\begin{array}{l}\text { Fathead minnow } \\
\text { Bluegill } \\
\text { Guppy }\end{array}$ & $\begin{array}{l}\text { Acute } \\
\text { Acute } \\
\text { Acute }\end{array}$ & $\begin{array}{l}10 \\
13 \\
50\end{array}$ & $\begin{array}{l}126 \\
126 \\
501\end{array}$ & $\begin{array}{l}1000 \\
1000 \\
3160\end{array}$ & $\begin{array}{l}\text { EPA 1980cc } \\
\text { EPA 1980cc } \\
\text { EPA 1980cc }\end{array}$ \\
\hline Toxaphene & Brook trout & Chronic & 0.01 & 0.063 & 0.40 & Mayer et al. 1975 \\
\hline 1,1,1-Trichloroethane & $\begin{array}{l}\text { Fathead minnow } \\
\text { Bluegill }\end{array}$ & $\begin{array}{l}\text { Acute } \\
\text { Acute }\end{array}$ & $\begin{array}{l}18 \\
32\end{array}$ & $\begin{array}{l}200 \\
316\end{array}$ & $\begin{array}{l}1580 \\
1580\end{array}$ & $\begin{array}{l}\text { AQUIRE: } \\
\text { AQUIRE" }\end{array}$ \\
\hline 1,1,2-Trichloroethane & Fathead minnow & Chronic & 1000 & 15800 & 251000 & Ahmad et al. 1984 \\
\hline Trichloroethene & $\begin{array}{l}\text { Fathead minnow } \\
\text { Flagfish } \\
\text { Bluegill }\end{array}$ & $\begin{array}{l}\text { Acute } \\
\text { Acute } \\
\text { Acute }\end{array}$ & $\begin{array}{l}13 \\
20 \\
32\end{array}$ & $\begin{array}{l}158 \\
251 \\
316\end{array}$ & $\begin{array}{l}1260 \\
1260 \\
1990\end{array}$ & $\begin{array}{l}\text { EPA 1980dd } \\
\text { Smith et al. } 1991 \\
\text { EPA 1980dd }\end{array}$ \\
\hline 2-Trifluoromethyl-4-phenol & Brook trout & Chronic & 100 & 501 & 3160 & Dwyer et al. 1978 \\
\hline Trifluralin & Fathead minnow & Chronic & 0.063 & 0.63 & 7.94 & Macek et al. $1976 b$ \\
\hline 1,3,5-Trinitrobenzene & $\begin{array}{l}\text { Fathead minnow } \\
\text { Rainbow trout } \\
\text { Rainbow trout }\end{array}$ & $\begin{array}{l}\text { Chronic } \\
\text { Chronic } \\
\text { Chronic }\end{array}$ & $\begin{array}{l}3.16 \\
13 \\
13\end{array}$ & $\begin{array}{l}50 \\
158 \\
158\end{array}$ & $\begin{array}{l}631 \\
1580 \\
1580\end{array}$ & $\begin{array}{l}\text { Van der Schalie } 1983 \\
\text { Van der Schalie } 1983 \\
\text { Van der Schalie } 1983\end{array}$ \\
\hline Vinyl acetate & $\begin{array}{l}\text { Fathead minnow } \\
\text { Bluegill } \\
\text { Guppy }\end{array}$ & $\begin{array}{l}\text { Acute } \\
\text { Acute } \\
\text { Acute }\end{array}$ & $\begin{array}{l}3.16 \\
10 \\
25\end{array}$ & $\begin{array}{l}40 \\
126 \\
251\end{array}$ & $\begin{array}{l}398 \\
794 \\
1580\end{array}$ & $\begin{array}{l}\text { AQUIRE" } \\
\text { AQUIRE" } \\
\text { AQUIRE }\end{array}$ \\
\hline
\end{tabular}

- EPA (n.d.) 


\section{DISTRIBUTION}

1. L. V. Asplund

2. R. R. Bonczek

3. M. Clauberg

4. J. Croswait

5. J. R. Duncan

6. R. E. Efroymson

7. K. M. Golden

8. R. K. Holmes

9. J. Jagoe

10. D. S. Jones

11-25. S. B. Kerr

26. J. M. Loar

27. D. M. Matteo

28. C. W. McGinn

29. D. B. Miller

30. J. H. Moyer

31. B. D. Nourse
32. D. M. Opresko

33. P. T. Owen

34. S. T. Purucker

35. A. S. Quist

36. B. E. Sample

37. D. M. Steinhauff

38-40. G. W. Suter

41. S. S. Talmage

42. M. F. Tardiff

43-44. C. L. Tsao

45. C. J. E. Welsh

46. D. C. White

47. M. E. Will

48. Central Research Library

49. ER Central Document Management Center

50. ORNL Laboratory Records

51. A. Temeshy, Bechtel National Inc., 151 Lafayette Dr., Oak Ridge, TN 37831-0350

52. M. Leslie, CDM Federal Programs Corporation, 800 Oak Ridge Turnpike, Suite 500, Oak Ridge, TN 37830

53. D. Gonzales, Jacobs Engineering, 125 Broadway, Oak Ridge, TN 37830

54. G. Snyder, Jacobs, Engineering, 100 West 3rd St., Piketon, OH 45611

55. J. Tate, Jacobs, Engineering, 125 Broadway, Oak Ridge, TN 37830

56. D. Wilkes, Jacobs, Engineering, 175 Freedom Blvd., Kevil, KY 42053

57. P. Carter, Science Applications International Corporation, 11197 U.S. Route 23, Suite 200, Waverly, Ohio 45690

58. B. Kornaby, Science Applications International Corporation, P.O. Box 2501, 301, Laboratory Rd., Oak Ridge, TN 37831

59. S. Pack, Science Applications International Corporation, P.O. Box 2501, 301, Laboratory Rd., Oak Ridge, TN 37831

60. B. G. Blaylock, SENES, 102 Donner Drive, Oak Ridge, TN 37831

61. K. Hopper, Systematic Management Services, 117 Broadway Ave., Oak Ridge, TN 37830 


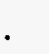

